\title{
Highways as potential barriers to movement and genetic exchange in small mammals
}

\author{
Final Report \\ February 2003
}

\author{
Submitted by \\ L. Scott Mills \\ Associate Professor \\ Wildlife Biology Program \\ University of Montana, School of Forestry \\ Missoula, MT 59812 \\ Reesa Yale Conrey \\ M.S. Student, Wildlife Biology Program and \\ Montana Cooperative Wildlife Research Unit \\ University of Montana \\ Missoula, MT 59812
}

Submitted to

Montana Department of Transportation

Research Section

2701 Prospect Avenue

Helena, MT 59620 


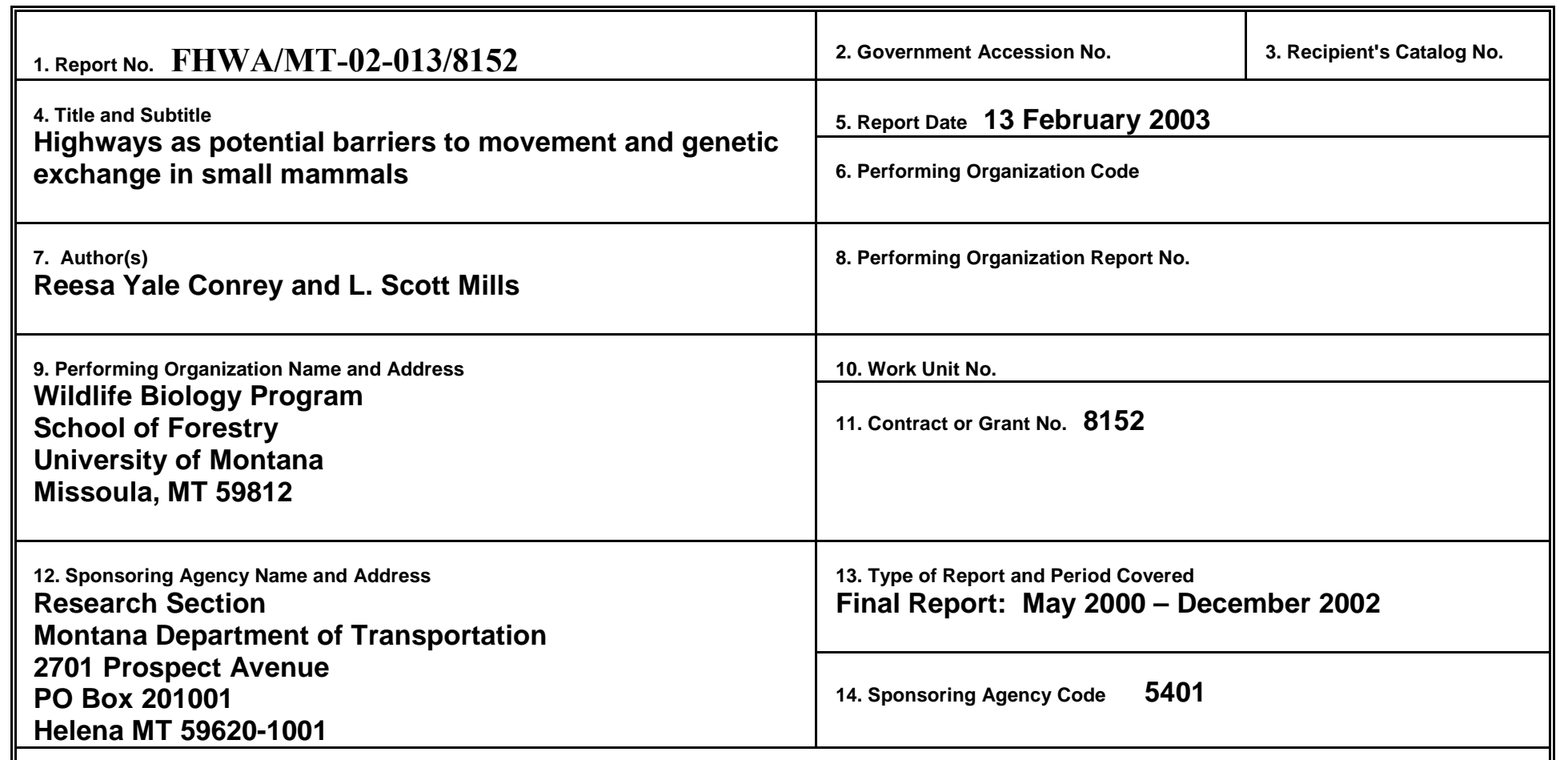

15. Supplementary Notes Research performed in cooperation with the Montana Department of Transportation and the US Department of Transportation, Federal Highway Administration.

16. Abstract Small mammal populations separated by highways may be partially or completely isolated from one another due to low dispersal capabilities, low probability of surviving highway crossing attempts, and/or avoidance of areas adjacent to highways. Our objective was to determine how population connectivity is influenced by highways of different widths and traffic levels for several small mammal species that may experience varying success in crossing highways. We used mark-recapture techniques to compare movement adjacent to highways to movement across highways for southern red-backed voles (Clethrionomys gapperi), deer mice (Peromyscus maniculatus), yellow pine chipmunks (Tamias amoenus), and red-tailed chipmunks (Tamias ruficaudus) in forested areas of western Montana. In addition, we used genetic techniques to compare gene flow (movement plus reproduction) adjacent to highways to gene flow across highways for red-backed voles, deer mice, and vagrant shrews (Sorex vagrans). Overall, 2.5 times more individuals moved adjacent to highways than across highways, and more crossed 2-lane than 4-lane highways. Observed movements varied among species, with forest-associated species (red-backed voles and chipmunks) more inhibited by highways than habitat generalists (deer mice). However, decreased movement has not yet led to genetic divergence for voles separated by highways. Gene flow across highways in deer mice was highly variable among sites, with an $11 \%$ decline in gene flow evident at one 4-lane highway site, in spite of relatively high numbers of observed movements at this site. Shrew gene flow was reduced by both 2- and 4-lane highways, and surprisingly, effect sizes (up to $37 \%$ decline) were largest for this habitat generalist.

17. Key Words

chipmunk, deer mouse, fragmentation, gene flow, highway, movement, population connectivity, red-backed vole, small mammal, vagrant shrew

19. Security Classif. (of this report) Unclassified
20. Security Classif. (of this page) Unclassified
18. Distribution Statement

Unrestricted. This document is available through the National Technical Information Service, Springfield, VA 21161.

21. No. of Pages 116 22. Price 


\section{PREFACE}

\section{Disclaimer}

This document is disseminated under the sponsorship of the Montana Department of Transportation and the United States Department of Transportation in the interest of information exchange. The State of Montana and the United States Government assume no liability of its contents or use thereof.

The contents of this report reflect the views of the authors, who are responsible for the facts and accuracy of the data presented herein. The contents do not necessarily reflect the official policies of the Montana Department of Transportation or the United States Department of Transportation

The State of Montana and the United States Government do not endorse products of manufacturers. Trademarks or manufacturers' names appear herein only because they are considered essential to the object of this document

This report does not constitute a standard, specification, or regulation.

\section{Alternative Format Statement}

The Montana Department of Transportation attempts to provide reasonable accommodations for any known disability that may interfere with a person participating in any service, program, or activity of the Department. Alternative accessible formats of this document will be provided upon request. For further information, call (406) 4447693 or TTY (406) 444-7696. 


\section{TABLE OF CONTENTS}

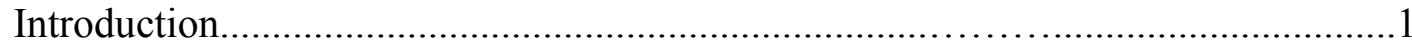

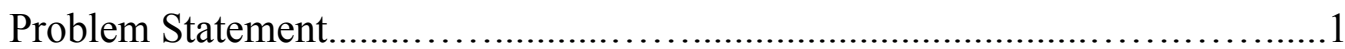

Background Summary....................................................................

Roads and Habitat Fragmentation...................................... 1

Small Mammals as Appropriate Study Organisms..........................2

Roads and Small Mammals.........................................................4

Small Mammal Study Species.................................................................6

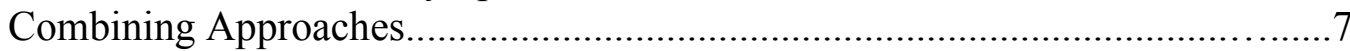

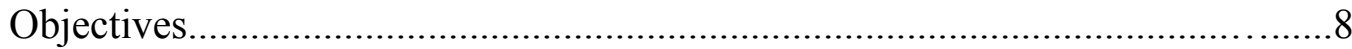

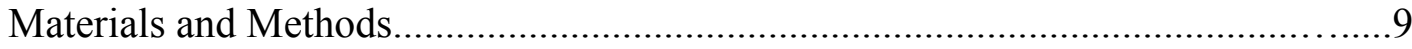

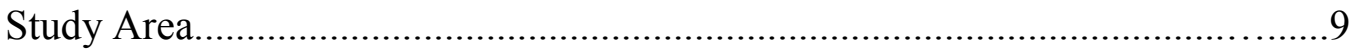

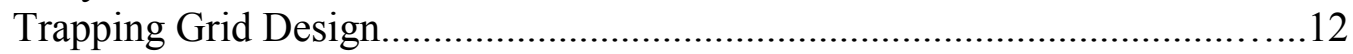

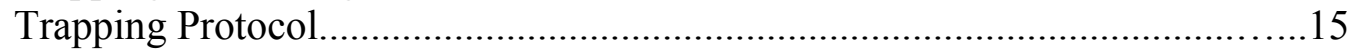

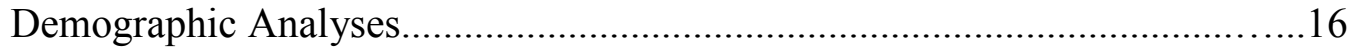

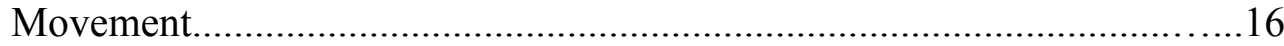

Abundance................................................................................ 17

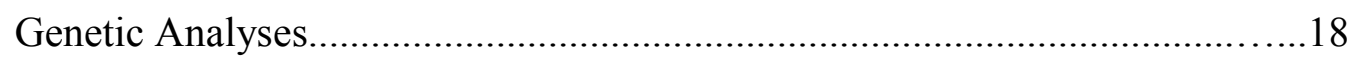

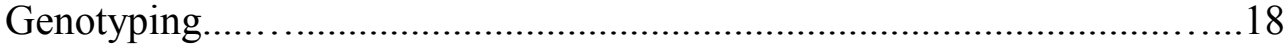

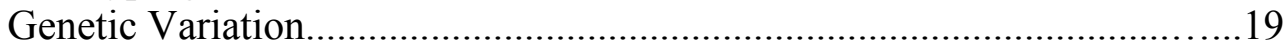

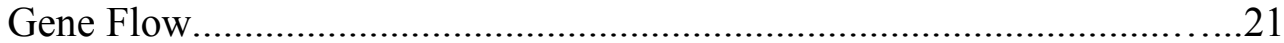

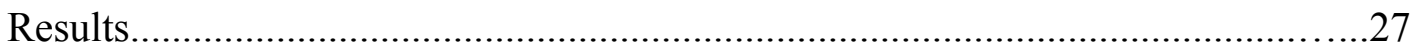

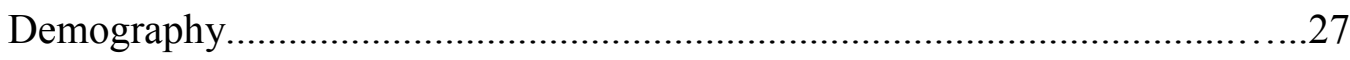

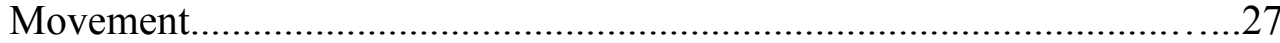

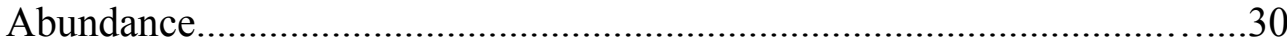

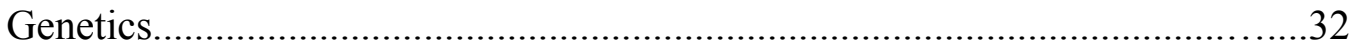

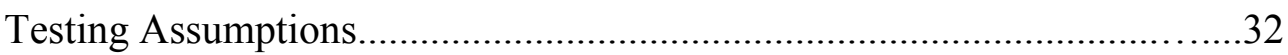

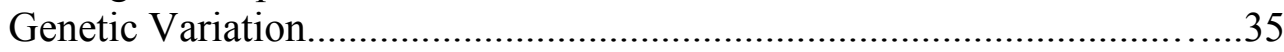

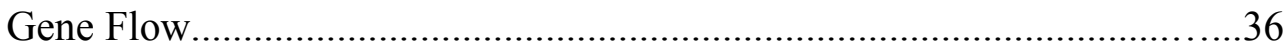

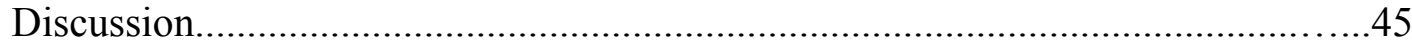

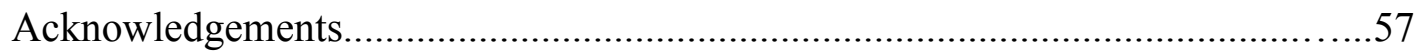

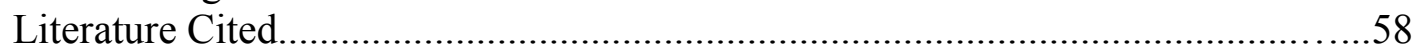

Appendix 1 - Small Mammal Abundance and Vegetation Surveys......................67

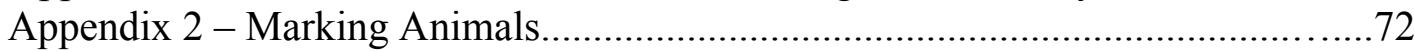

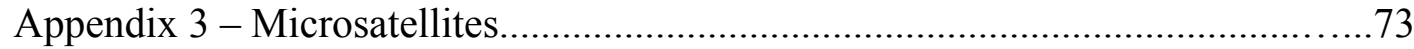

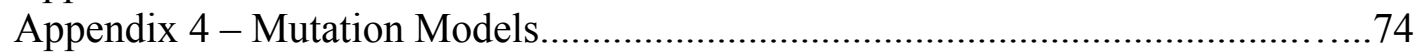

Appendix 5 - Hardy-Weinberg and Linkage Disequilibrium...............................76

Appendix 6 - Measuring Genetic Differentiation............................................ 78

Genetic Distance: Wright's F

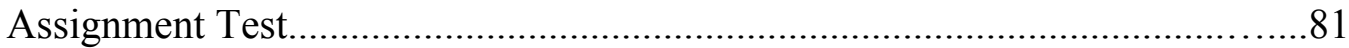

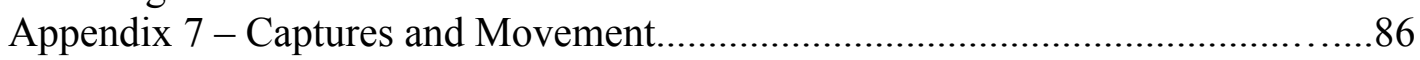

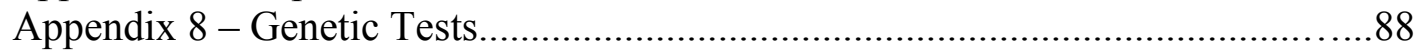

Appendix 9 - Heterozygosity and Allelic Diversity............................................99

Appendix 10 - Genetic Differences Among Sites.............................................107

Appendix 11 - Gene Flow within Sites.............................................................114 


\section{LIST OF TABLES}

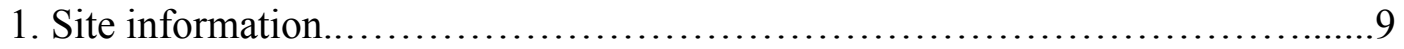

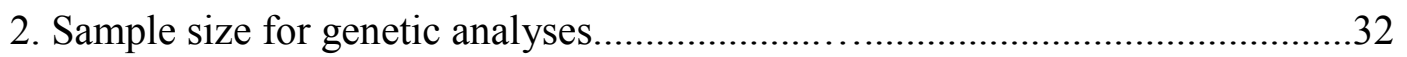

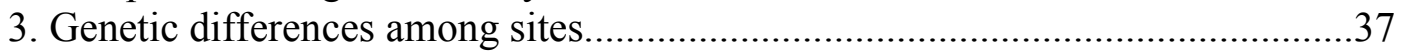

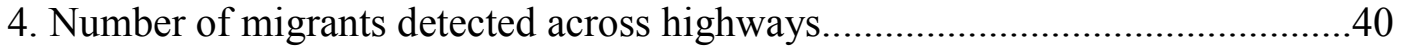

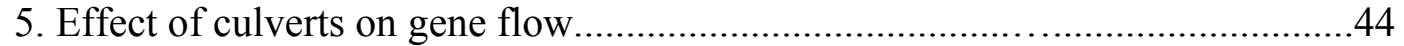

6. Do highways reduce small mammal movement?......................................45

\section{LIST OF FIGURES}

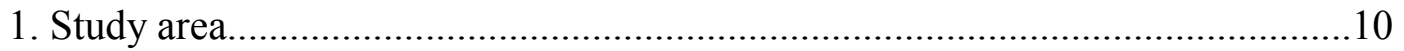

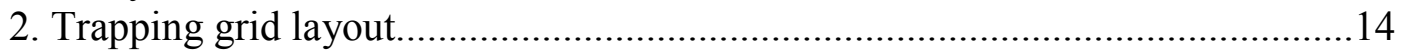

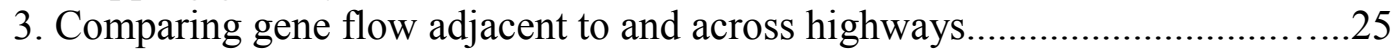

4. Percentage of individuals that moved............................................................29

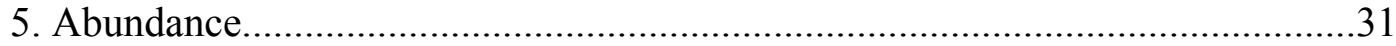

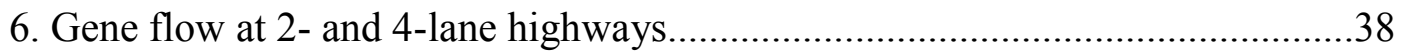

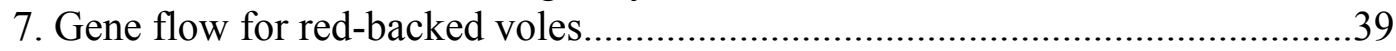

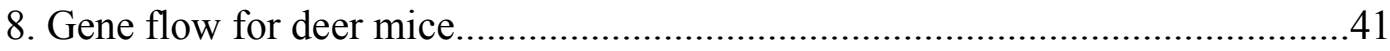

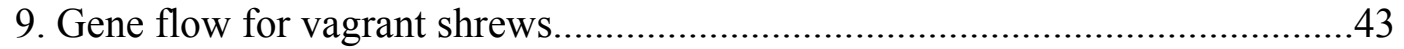




\section{LIST OF TABLES IN APPENDICES}

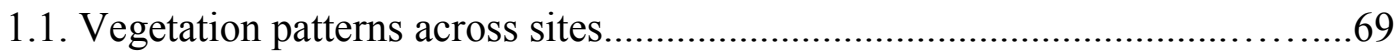

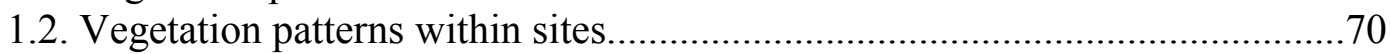

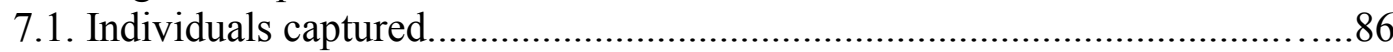

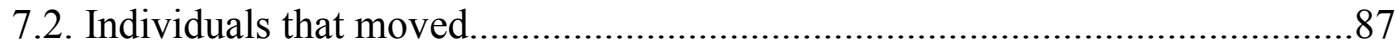

7.3. Movement adjacent to versus across highways......................................... 87

8.1. Population differentiation among 2000 and 2001 red-backed vole samples...88

8.2. Tests indicating Hardy-Weinberg disequilibrium for red-backed voles...........88

8.3. Tests indicating linkage disequilibrium for red-backed voles.......................89

8.4. Percentage of tests in which linkage was detected for red-backed voles.........90

8.5. Population differentiation among 2000 and 2001 deer mouse samples...........91

8.6. Tests indicating Hardy-Weinberg disequilibrium for deer mice....................91

8.7. Tests indicating linkage disequilibrium for deer mice..............................93

8.8. Percentage of tests in which linkage was detected for deer mice...................96

8.9. Population differentiation among 2000 and 2001 vagrant shrew samples.......97

8.10. Tests indicating Hardy-Weinberg disequilibrium for vagrant shrews...........97

8.11. Tests indicating linkage disequilibrium for vagrant shrews.......................98

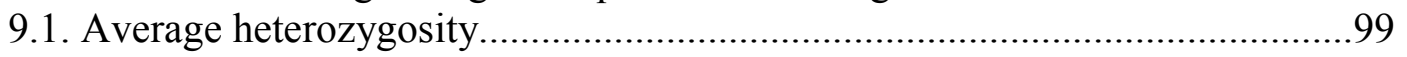

9.2. Site specific heterozygosity for red-backed voles....................................101

9.3. Number of alleles per locus for red-backed voles...................................... 102

9.4. Site specific heterozygosity for deer mice..............................................103

9.5. Number of alleles per locus for deer mice................................................. 104

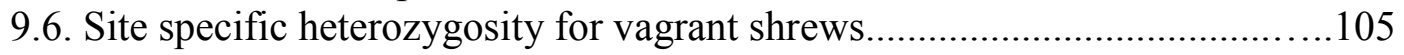

9.7. Number of alleles per locus for vagrant shrews.......................................106

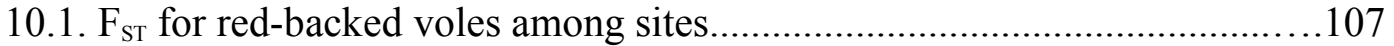

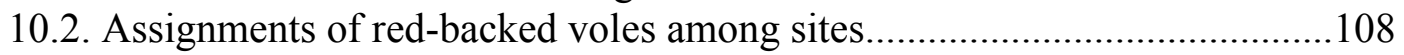

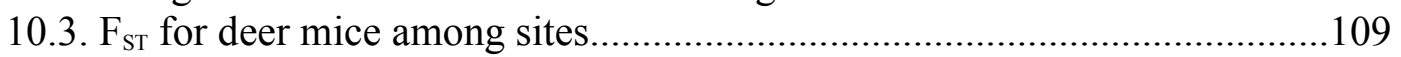

10.4. Assignments of deer mice among sites............................................... 110

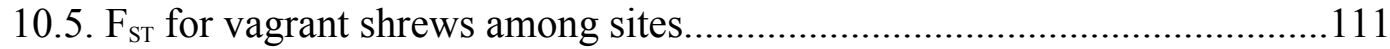

10.6. Assignments of vagrant shrews among sites.......................................... 112

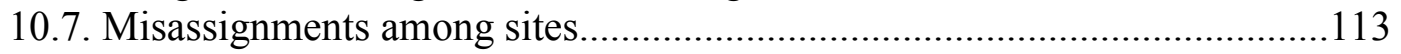

11.1. Gene flow across highways for red-backed voles..................................114

11.2. Gene flow across highways for deer mice..............................................115

11.3. Gene flow across highways for vagrant shrews......................................116 


\section{INTRODUCTION}

\section{Problem Statement}

Roads, especially large highways, can adversely impact wildlife populations by increasing mortality due to vehicular collisions and by discouraging crossing attempts. Small mammal populations separated by highways may be partially or completely isolated from one another due to low dispersal capabilities, low probability of surviving highway crossing attempts, and/or avoidance of areas adjacent to highways. Threats to small mammals are problematic at the ecosystem level because of their importance in ecosystem processes, such as seed and sporocarp dispersal, and because of their role as prey for predators such as lynx, marten, fisher, and raptors. Thus, as the human population continues to increase, and pressures mount for wider roads to accommodate more traffic, it is imperative that transportation planners understand the potential negative effects of these roads on wildlife and how to mitigate them.

\section{Background Summary}

\section{Roads and Habitat Fragmentation}

Habitat loss and fragmentation are the primary threats to wildlife today. One potential agent of habitat loss and fragmentation that was long ignored is our system of roads and highways. Roads occupy a considerable area of land and form extensive longitudinal obstacles. Permeability of these potential barriers to wildlife depends on road width, traffic volume, the placement of fencing or concrete barriers, vegetation characteristics along the road corridor, the existence of culverts or overpasses, and physical abilities and behavioral characteristics of potential crossers. 
Harmful effects of roads on wildlife may include mortality, disturbance due to emissions and noise, habitat loss and modification, intrusion of edge effects, and subdivision of populations (Andrews 1990). Of course, not all species experience negative effects; generalists and species adapted to open areas may benefit from the altered environment, responding positively to novel food sources or edge effects. Roads can cause changes in home ranges, movement, reproductive success, escape response, and physiological state, and have been correlated with changes in species composition and population sizes (Trombulak and Frissell 2000).

\section{Small Mammals as Appropriate Study Organisms}

Small mammals are both important ecological interactors and tractable study organisms for investigating the effects of highways on population connectivity. Deer mice (Peromyscus maniculatus) are the primary predator on seeds that reach the forest floor (Adams 1950; Schmidt and Shearer 1971), and chipmunks (Tamias spp.) are also important predators on conifer seeds. Chipmunks cache seeds and forget the location of some caches, facilitating seed dispersal and tree reproduction. Seeds from more than 20 species of pine are dispersed by birds and rodents (Vander Wall 1993). They improve germination by carrying seeds away from the parent tree, allowing colonization of new habitats, and by burying them. In contrast, seeds dispersed by wind tend to fall on the surface near the parent tree. Tevis (1953) suggested that the yellow pine chipmunk (Tamias amoenus) was important in affecting stand regeneration in northeastern California, and Vander Wall (1993) showed that yellow pine chipmunks were more effective, higher quality seed dispersers than wind. 
Shrews (Sorex spp.) and deer mice are important insect predators, and may control insect pest populations in some circumstances (Buckner 1958; Frank 1967). Platt and Blakley (1973) suggested that the masked shrew (Sorex cinereus) functioned as a keystone predator by suppressing populations of dominant insect competitors. Anderson and Folk (1993) showed that shrews and deer mice reduced survival in acorn weevil populations, important forest pests.

Many higher plant species depend on a symbiotic relationship with mycorrhizal fungi to meet their nutritional requirements (Marks and Kozlowski 1973; Sanders et al. 1975). Most ectomycorrhizal fungi produce fruiting bodies that develop underground, relying on mammals to dig up and eat the fruiting bodies, dispersing spores in their feces (Johnson 1996). The northern flying squirrel (Glaucomys sabrinus) and the California red-backed vole (Clethrionomys californicus) are almost exclusive mycophagists (Maser et al. 1978; Maser et al. 1985; Hayes et al. 1986). The southern red-backed vole (Clethrionomys gapperi) replaces the California red-backed vole in the Rocky Mountains, and is also an important mycophagist (Ure and Maser 1982; Gunther et al. 1983), although this species is more opportunistic in its consumption of truffles. Deer mice and chipmunks also eat sporocarps opportunistically, and are more likely to deposit spore-containing feces in adjacent nonforested areas than are voles (Maser et al. 1978; Li et al. 1986).

Many predators depend on a small mammal prey base for at least part of the year. For example, red-backed voles are the primary food source for American pine marten (Martes americana) (Weckwerth and Hawley 1962; Buskirk and Ruggiero 1994) and boreal owls (Aegolius funereus: Hayward et al. 1993). Small mustelids such as least 
weasels (Mustela nivalis) also prey heavily on small mammals (Norrdahl and Korpimaki 1998). Numerous other mammalian and avian predators prey opportunistically on small mammals.

In addition to being ecologically important, small mammals are tractable organisms for studying the effects of highways on population connectivity in wildlife over a short time frame. Due to relatively high densities and willingness to go into traps, small mammals can be captured in relatively high numbers, and handling is not difficult. Small mammals have short generation times, so they have the potential to show the signature of population subdivision long before it becomes detectable in longer-lived species.

\section{Roads and Small Mammals}

Roads may hinder some small mammal species very little, while presenting near absolute barriers to others. For example, Mader (1984) found that none of the 121 marked small rodent individuals in his study crossed a $6 \mathrm{~m}$ two-lane paved highway in Germany, although numerous movements occurred parallel to the highway, and several species could theoretically have crossed within a few seconds. Even very small roads can function as barriers to wildlife. On a narrow $(3 \mathrm{~m})$ dirt road that received only $10-20$ vehicles per day, Swihart and Slade (1984) observed inhibition of movement across the road in prairie voles (Microtus ochrogaster) and cotton rats (Sigmodon hispidus), although movement rates were likely high enough in this case to maintain gene flow across the road. Oxley et al. (1974) trapped small mammals adjacent to roads ranging from gravel to 4-lane divided highways. In the two most abundantly captured species, 
only $3 \%$ of white-footed mice (Peromyscus leucopus) crossed roads, and only one of these crossed a road as large as a 2 -lane highway. Only $3 \%$ of eastern chipmunks (Tamias striatus) crossed, and these crossed only gravel, not paved, roads. However, Oxley et al. (1974) found that mammals adapted to open country ventured onto roads with apparent readiness in comparison to the caution shown by small forest-adapted mammals. In the first study to investigate the genetic effects of roads, Gerlach and Musolf (2000) demonstrated genetic subdivision in bank voles (Clethrionomys glareolus) separated by a 4-lane highway in Germany that had been present for 25 years (although the degree of subdivision was small). Several authors have suggested that divided highways with clearances of $90 \mathrm{~m}$ may be barriers as effective in hindering the dispersal of small forest mammals as bodies of fresh water twice as wide (Werner 1956; Sheppe 1965).

The impacts of road width and traffic volume on wildlife crossings have also been investigated in a few areas. A significant correlation was found between number of vehicles and number of snakes found dead or mortally injured on roads in the Everglades (Bernardino and Dalrymple 1992). In a study that attempted to identify the most important factors inhibiting small mammal movement across roads, Oxley et al. (1974) concluded that the clearance distance between habitats on either side of the road was more important than traffic volume or any other factor. Wilkins and Schmidly (1980) reported that highway mortality for mammals was highest on a highway with intermediate traffic volume, lowest on a highway with low volume, and intermediate at high volume, presumably because mammals did not attempt to cross high volume highways as often as those with low or intermediate traffic volume. Similar to Wilkins 
and Schmidly's (1980) finding for mammals, Fahrig et al. (1995) found that the total number of frogs and toads on roads decreased as traffic intensity increased, but the proportion of dead to living anurans increased as traffic intensity increased.

\section{Small Mammal Study Species}

We chose our study species based on both ecological interest and logistical concerns. We focused on red-backed voles (Clethrionomys gapperi), deer mice (Peromyscus maniculatus), yellow pine chipmunks (Tamias amoenus), red-tailed chipmunks (Tamias ruficaudus), and vagrant shrews (Sorex vagrans) because they exhibit a wide range of ecological roles, habitat requirements, and behavioral characteristics (Pearson 1999; Foresman 2001 a). Along a continuum from strong forestassociate $\rightarrow$ habitat generalist, the order of these species would be red-backed vole, redtailed chipmunk, yellow pine chipmunk, vagrant shrew, and deer mouse. Deer mice are extremely widely distributed and are found in a wide variety of habitats (Pattie and Verbeek 1967; Hoffmann and Pattie 1968; Foresman 2001 a), as are vagrant shrews, although shrews seem to require a somewhat wetter environment with a more developed understory (Clothier 1955; Spencer and Pettus 1966; McCracken 1990; Foresman 2001 a). In contrast, red-backed voles live mainly in moist, densely-forested areas with a developed understory and abundant coarse woody debris (Gunderson 1959; Pearson 1994; Foresman 2001 a), and are indicators for old growth conditions in the Rocky Mountains (USDA Forest Service 1985). Yellow pine chipmunks occur in dry, open forest stands (locally, in fairly open low elevation ponderosa pine/Douglas fir forests), while red-tailed chipmunks occur only in denser stands (Foresman 2001 a). Deer mice 
typically respond positively to edges and to clearcuts (Sullivan 1979; Sekgororoane and Dilworth 1995; Tallmon et al. In Prep), while voles tend to prefer the forest interior (or sometimes edge habitat: Lair 2001), and shrews and chipmunks tend to show no avoidance of or attraction to edges (Sekgororoane and Dilworth 1995).

We analyzed data only for those small mammal species that were abundant enough in our sample to make the analyses statistically possible and biologically meaningful. Therefore, our study species are abundant and widely-distributed, unlikely to face extinction even if movement across highways is quite rare. However, by focusing on this group of species, our goal was to represent a wide range of potential responses to highways, thereby providing information that might be useful in considering the effects of highways on rarer species of concern for which data collection was impossible.

\section{Combining Approaches}

Although several studies have investigated abundance and movement of small mammals near roads (reviews by Andrews 1990; Bennett 1991; Spellerberg 1998; Trombulak and Frissell 2000), and one has measured genetic effects of roads (Gerlach and Musolf 2000), none has done both. Demographic (mark-recapture) data can provide information about current movement and characteristics of study organisms (such as sex and age), but the limitation is that movement can only be inferred where it is detected through trapping. Unless an individual is captured before and after it moves, the event will go unrecorded. Moreover, mark-recapture data cannot reveal whether individuals that move actually breed, linking populations through gene flow. While genetic data can address these concerns, it may be difficult to detect recent population fragmentation using 
genetics, because all tests of population subdivision depend on differences in gene frequencies to detect an effect, and these differences take time to develop, even in isolated populations. Thus, we have combined demographic and genetic approaches to gain insight into past and present movement and gene flow (Mills and Tallmon 1999; Mills et al. In Press) across highways.

\section{Objectives}

Our objective was to determine how movement and gene flow are affected by highways of different widths and traffic levels for several small mammals with varying habitat associations. We used a mark-recapture approach to compare movement adjacent to highways to movement across highways for southern red-backed voles, deer mice, yellow pine chipmunks, and red-tailed chipmunks in forested areas of western Montana.

We also examined gene flow (movement plus reproduction) adjacent to versus across highways in red-backed voles, deer mice, and vagrant shrews. Our goal was to assess the barrier effect of highways of different widths on these species, so that these negative impacts can be identified and mitigated in the future.

We tested the following hypotheses:

1) Movement rates (and gene flow) across highways are decreased relative to movement rates adjacent to highways.

2) 4-lane highways are a more significant barrier than 2-lane highways.

3) Impacts of highways are stronger for forest-associates than for habitat generalists. Specifically, we predicted that red-backed voles (preferring dense forest cover), would be 
more deterred by highways than deer mice (using a wide variety of habitats), and that chipmunks and shrews would have an intermediate response.

\section{MATERIALS AND METHODS}

\section{Study Area}

We established replicate trapping grids at three 2-lane and two 4-lane forested highway sites in western Montana (Table 1; Figure 1). Two-lane sites were located on 1) Highway 12 just west of Lolo Hot Springs, 2) State Highway 200 in the Lubrecht Experimental Forest, and 3) Highway 83 between Lake Alva and Rainy Lake. Four-lane sites were located on I-90, one just east of St. Regis, and the other near Tarkio. These sites will hereafter be referred to as Lolo, Lubrecht, Rainy Lake, St. Regis, and Tarkio.

\section{Site Information}

\begin{tabular}{|c|c|c|c|c|c|}
\hline & Lolo & Lubrecht & Rainy Lake & St. Regis & Tarkio \\
\hline Number of lanes & 2 lanes & 2 lanes & 2 lanes & 4 lanes & 4 lanes \\
\hline Highway ID & 12 : mile 6.5 & 200: mile 22.5 & 83: mile 26.5 & I-90: mile 36 & I-90: mile 63.5 \\
\hline Pavement width & $12 \mathrm{~m}$ & $14 \mathrm{~m}$ & $12 \mathrm{~m}$ & $24 \mathrm{~m}$ & $24 \mathrm{~m}$ \\
\hline Median width & none & none & none & $51 \mathrm{~m}$ & $12 \mathrm{~m}$ \\
\hline Traffic volume & $1300 \mathrm{veh} /$ day & $2900 \mathrm{veh} /$ day & $1100 \mathrm{veh} /$ day & $5900 \mathrm{veh} /$ day & $6500 \mathrm{veh} /$ day \\
\hline $\begin{array}{l}\text { Year } \\
\text { paved/widened }\end{array}$ & $1954 /-$ & $1941 /-$ & $1956 /-$ & $1920 \mathrm{~s} / 1980$ & $1920 \mathrm{~s} / 1982$ \\
\hline $\begin{array}{l}\text { Distance from } \\
\text { pavement edge } \\
\text { to forest edge }\end{array}$ & $5 \mathrm{~m}$ & $10 \mathrm{~m}$ & $2 \mathrm{~m}$ & $25 \mathrm{~m}$ & $30 \mathrm{~m}$ \\
\hline $\begin{array}{l}\text { Distance from } \\
\text { forest edge to } \\
\text { forest edge }\end{array}$ & $22 \mathrm{~m}$ & $34 \mathrm{~m}$ & $16 \mathrm{~m}$ & $125 \mathrm{~m}$ & $96 \mathrm{~m}$ \\
\hline $\begin{array}{l}\text { Species captured } \\
\text { and analyzed }\end{array}$ & $\begin{array}{l}\text { RB voles } \\
\text { Chipmunks } \\
\text { Shrews }\end{array}$ & $\begin{array}{l}\text { RB voles } \\
\text { Deer mice } \\
\text { Chipmunks }\end{array}$ & $\begin{array}{l}\text { RB voles } \\
\text { Deer mice } \\
\text { Chipmunks } \\
\text { Shrews }\end{array}$ & $\begin{array}{l}\text { RB voles } \\
\text { Deer mice } \\
\text { Chipmunks } \\
\text { Shrews }\end{array}$ & $\begin{array}{l}\text { Deer mice } \\
\text { Chipmunks }\end{array}$ \\
\hline
\end{tabular}

Table 1. Information on areas where small mammals were sampled. 


\section{Study area}

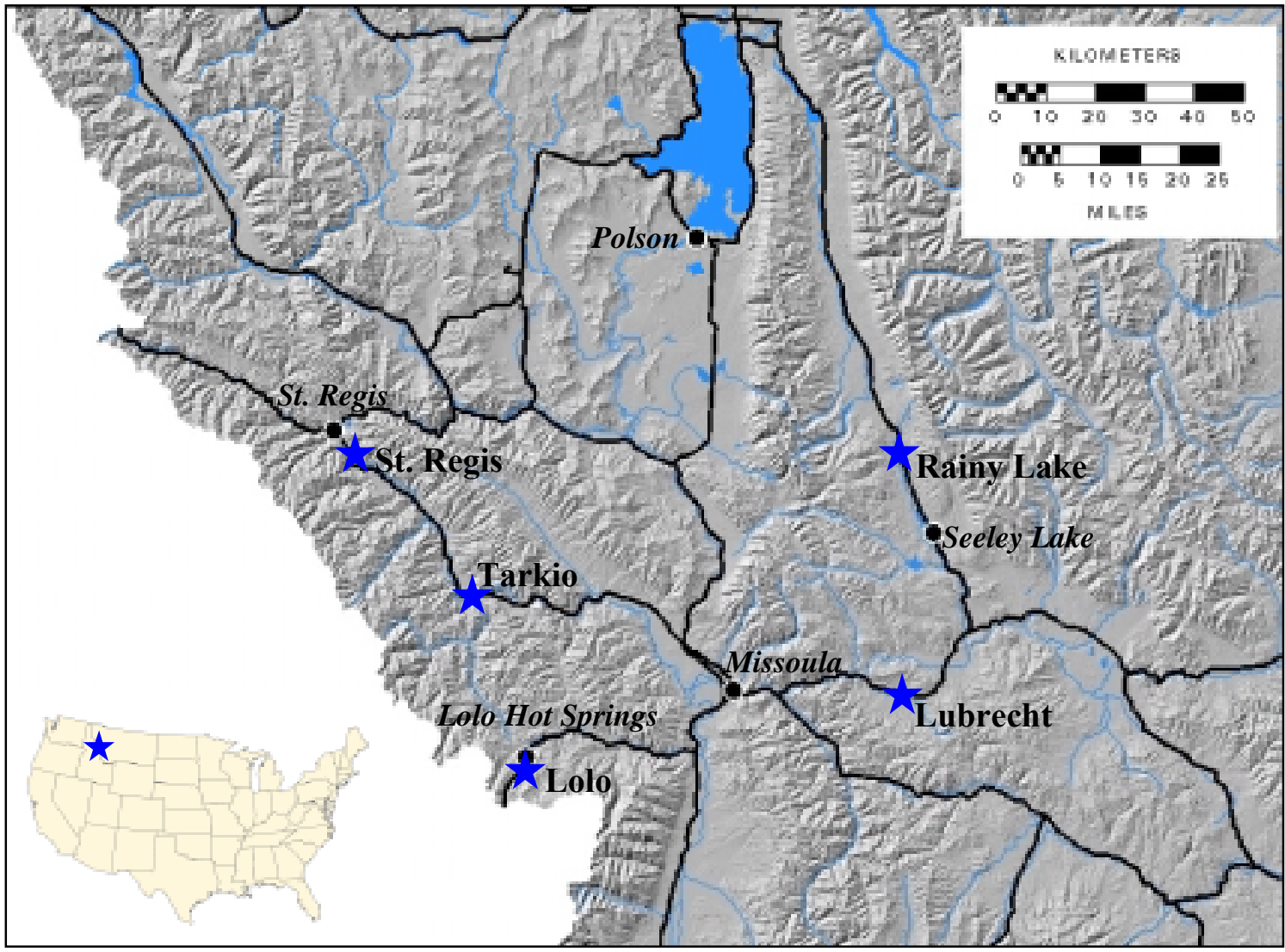

Figure 1. Study sites are marked by stars, and nearby towns are noted in italics. Study sites starting at St. Regis (I-90) and moving counter-clockwise are Tarkio (I-90), Lolo (Highway 12), Lubrecht (State Highway 200), and Rainy Lake (Highway 83). 
These five sites represented the only areas within two hours drive of Missoula that were suitable for this study. We selected only undeveloped forested sites that were relatively flat and situated around a fairly straight stretch of road, avoiding steep, rocky terrain and curvy stretches of road that would have complicated the establishment of four square, equidistant trapping grids around the highway. The predominance of rivers, railroad tracks, and frontage roads near highways restricted the pool of sites, because they form potential barriers that would have confounded our analyses of highway effects. We chose sites that were undeveloped and lacked concrete barriers or fencing that might restrict small mammal movement, because we wanted to maximize our chances of detecting movement across highways where it was likely to occur. Three of our sites contained culverts. At Rainy Lake, a culvert conducted a permanent stream under the road bed at the southernmost end of our trapping grids. The other two culverts remained mostly dry during our study. At St. Regis, a culvert connected the northwest trapping grid to the median strip, but went no farther. At Tarkio, a culvert near our eastern trapping grids ran between the north and south sides of the highway, but did not open directly into our trapping grids.

The vegetation at these sites is somewhat variable, but all sites are dominated by ponderosa pine and Douglas-fir (for information on vegetation surveys in this study, see Appendix 1). Rainy Lake and St. Regis are dense, moist sites near the highway, but both of these sites have been thinned starting around $75 \mathrm{~m}$ from the highway. Tarkio is a very dry, open, managed stand of ponderosa pine, with very little undergrowth. Lubrecht has vegetative structure intermediate to that of the previously mentioned sites. Lolo has variable vegetation due to the presence of Lolo Creek on the south side of the highway. 
Dryer ponderosa pine - Douglas-fir forest dominates on the north side of the highway and near the highway on the south side, but riparian vegetation is common near the creek.

At our 2-lane sites, the forest edge was quite near the pavement edge; distances were larger at our 4-lane sites (Table 1). At Lolo, there was a small grassy area coming down from the slightly raised roadbed to the forest (or to a mesic area with high shrub cover, for the easternmost part of our eastern trapping grids). At Lubrecht, the slope from the road bed to the forest edge varied from a slight slope up, to level, to a very slight slope down to the forest; this area between the pavement and the forest edge was grassy, except that the up-slope area was sparsely covered by seedlings and small saplings. There was essentially no shoulder at our Rainy Lake site, so the forest edge was only 1 $2 \mathrm{~m}$ from the pavement edge, separated by a strip of grass. In contrast, the area bordering our 4-lane highway, I-90, was mowed periodically by the Montana Department of Transportation, and the forest edge was $25-30 \mathrm{~m}$ from the pavement edge. At St. Regis, our first one or two rows of traps were set in an open, grassy area with few trees or shrubs. These open areas sloped gently up or down from the roadbed. At Tarkio, a level, grass and gravel area bordered the highway. The grass and gravel blended into an area covered in spotted knapweed and sparse ponderosa pine trees. Our first two rows of traps were set in this knapweed / ponderosa pine area, with the rest of the traps located within the pine forest.

\section{Trapping Grid Design}

We live-trapped small mammals in the summers of 2000 and 2001. At each site, there were four equidistant highway trapping grids (Figure 2), two on one side of the 
highway and two on the other. This design permitted the comparison of movement rates adjacent to the highway versus across the highway. Each grid was square and contained seven traps by seven traps, for a total of 49 traps per grid and 196 traps per site. Traps were $15 \mathrm{~m}$ apart, and grids were $75 \mathrm{~m}$ apart. The distance of grids from the highway varied from site to site due to differences in highway width. We chose to maintain constant distance between grids, rather than constant distance from grids to the highway, so that we could remove distance as a nuisance variable that would have confounded the analysis of movement rates across 2- and 4-lane highways.

In 2001, we added to the study design at three sites (Lubrecht, Rainy Lake, and St. Regis): two additional grids in the forest interior, $75 \mathrm{~m}$ from the original highway grids on one side of the highway, for a total of six trapping grids. The addition of forest interior grids essentially provided another within-site replicate, and also allowed comparisons of small mammal abundance near the highway versus the forest interior; logistical constraints limited us to only one side of the highway and three sites. This expansion of the project was possible because of a collaboration with a student completing his undergraduate senior thesis, Jeremy Moran. In addition, J. Moran assessed a number of vegetation variables (Appendix 1). 


\section{Trapping grid layout}

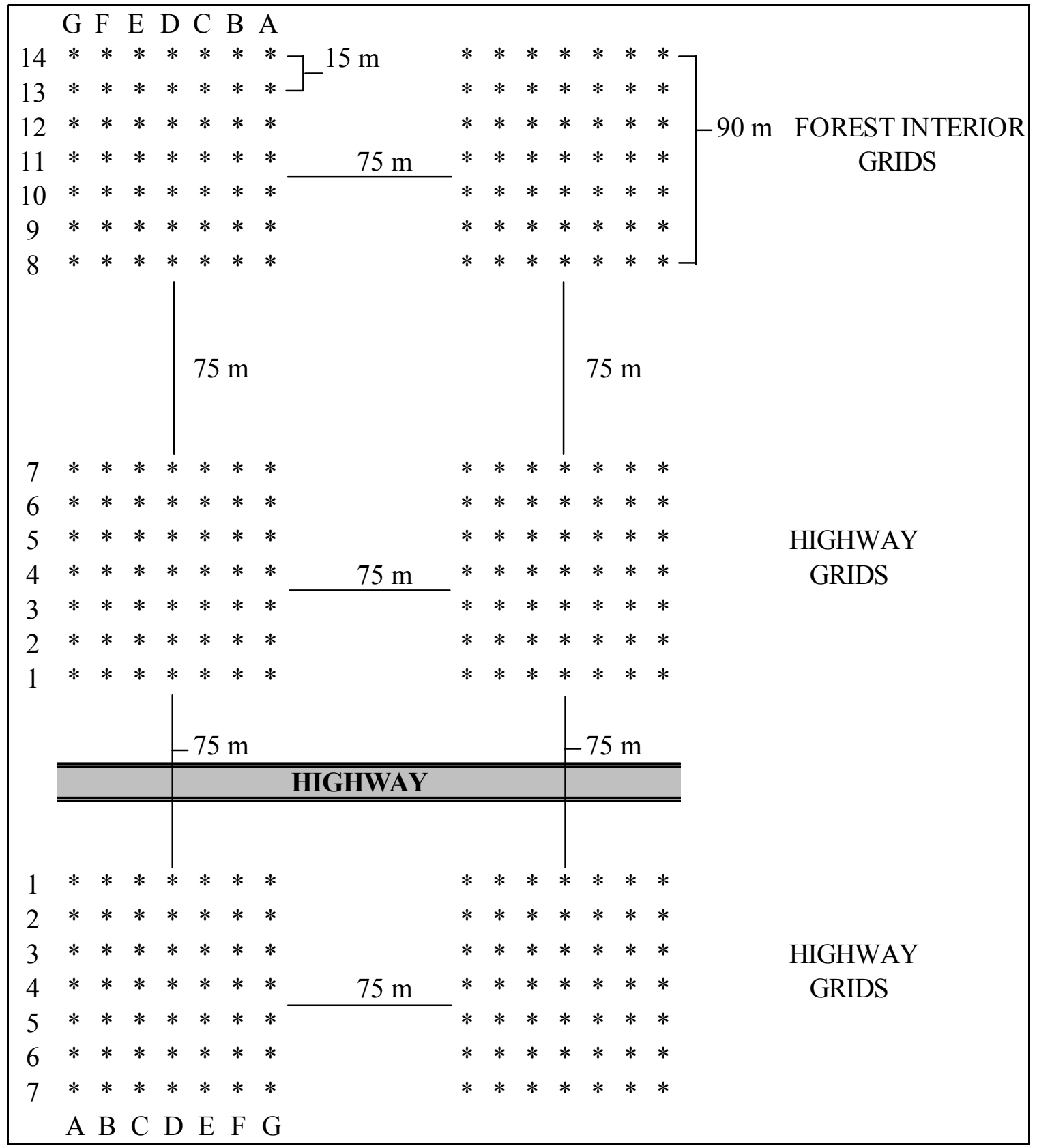

Figure 2. Layout of trapping grids at a site. Each dot represents a Sherman live trap. Four square (7 traps by 7 traps), equidistant grids were bisected by the highway; two additional grids were located in the forest interior on one side of the highway at three sites (Lubrecht, Rainy Lake, and St. Regis) in 2001 only. There were 49 traps per grid, for a total of 294 traps at these three sites and 196 traps at Tarkio and Lolo. Traps were spaced $15 \mathrm{~m}$ apart, and grids were $90 \mathrm{~m}$ by $90 \mathrm{~m}$. Grids were $75 \mathrm{~m}$ apart, so distance from the edge of the highway varied with highway width. At each site, highway trapping grids were denoted NE, $\mathrm{NW}, \mathrm{SE}$, and SW, based on their position around the highway. Highways run east-west except at Rainy Lake, where the highway runs north-south. Forest interior grids were denoted NE1, NW1, and so on. 


\section{Trapping Protocol}

During summer 2000 and 2001, we used large baited Sherman traps $(9 \times 8 \times 23$ $\mathrm{cm})$ to live-trap small mammals. Traps were baited with sunflower seeds, oat groats, and apple (for moisture). Traps also contained water-repellent polyester batting for warmth, and were placed inside treated cardboard milk cartons to regulate temperatures inside the traps and repel water. Whenever possible, we placed traps near woody debris, trees, or some other form of cover within a $1 \mathrm{~m}$ radius of the grid point location, in order to maximize probability of capture. We followed this trap placement protocol at every trap location at every site. At each site, we prebaited for two to four days to increase capture probability.

Trapping sessions consisted of three consecutive nights of trapping separated by 25 days. We opened traps between 17:30 and 20:00, and closed traps after checking them the next morning, starting at 7:00. Because trapping effort was concentrated during the night, capture probability was maximized for mostly nocturnal species like redbacked voles, deer mice, and shrews. We were willing to sacrifice some daylight trapping hours that may have increased diurnal chipmunk captures in order to minimize mortality in other species. Our goal was to trap each site at least three times per year, which is necessary for estimation of survival and movement in open populations. However, logistical limitations, including forest closures due to fire, meant that in summer 2000 Lubrecht was trapped four times, Lolo was trapped twice, and all other sites were trapped three times; during summer 2001, we trapped each site three times.

For each captured individual, we recorded species, ID number, sex, reproductive condition, weight, tail length, and any other unique characteristics or comments that 
described the animal's condition. The ID number was assigned at first capture via toe clipping or ear tags (Appendix 2). Mice and voles were marked by toe clipping, which has the additional benefit of providing a tissue sample for genetic analysis (tissues were stored in silica gel). Chipmunks and bushy-tailed woodrats, which are too large for toe clipping, were marked with small numbered metal ear tags. Although we did not assess gene flow for these species, we archived a small hair sample for possible future genetic analyses.

Shrews are strict insectivores, and were not targeted for capture (traps were baited with seeds and fruit). Nevertheless, we captured many shrews, $70 \%$ of which had perished overnight in the trap due to extremely high metabolic rates that require shrews to move and feed almost constantly. Live shrews were released, and deceased shrews were collected for genetic analysis. Species determination for shrews occurred in the lab through an examination of dentition (Foresman 2001 b), because species are not easily distinguished in the field.

\section{Demographic Analyses}

\section{Movement}

To assess the effect of highways on small mammal movement, we compared movement adjacent to highways to movement across highways, where a movement was defined as an initial capture in one trapping grid, and subsequent capture in a different trapping grid. Therefore a movement was of minimum length $75 \mathrm{~m}$, the distance between trapping grids. If the grid of previous capture was diagonal (across the highway) from the grid of subsequent capture, then two movements were noted: one adjacent to and one 
across the highway. Some individuals moved more than once. We used logistic regression to determine which factors best explained movement, where the response variable had two possible values: movement adjacent to or movement across highways. We investigated the importance of several factors, including highway width (2- or 4lane), species (red-backed vole, deer mouse, or chipmunk), sex, site, and year. We used a chi-square to test whether movement adjacent to highways was more or less common than movement across highways for each species separately, and for all species combined, comparing observed movements to the null hypothesis of half of the movements adjacent to and half across the highway.

\section{Abundance}

For his undergraduate senior thesis, Jeremy Moran estimated the abundance of red-backed voles, deer mice, and chipmunks in the highway/forest edge trapping grids and in the forest interior grids. He predicted that an ecological "fence effect" (Krebs et al. 1969; Lidicker 1975; Gliwicz 1980; Gaines and Johnson 1987) was occurring: dispersing individuals encounter highways that frustrate their dispersal, so abundances are higher near highways than in the forest interior. Lincoln-Petersen estimates (Seber 1982) of monthly abundance were calculated, assuming that populations were closed within 3-day trapping sessions (meaning that no individuals were added to or removed from the population during this time). The fence effect hypothesis was tested indirectly by comparing abundance in highway edge grids to abundance in forest interior grids, and was evaluated relative to the alternative hypothesis that abundance patterns are determined purely by chance or by vegetation characteristics. For each vegetation 
variable (Appendix 1), plot averages were calculated and combined for mean (and standard error) values across the 14 plots ( 7 per grid) making up the two interior and two highway grids at each site (on one side of the highway).

\section{Genetic Analyses}

In addition to demographic analyses of mark-recapture data, we analyzed genetic information obtained from tissue samples from each red-backed vole, deer mouse, and vagrant shrew that we captured. Our goal was to quantify relative genetic differences between animals in trapping grids on the same side of highways versus those separated by highways. Genetic differences between populations (defined here as trapping grids) result when gene flow is limited by some factor, such as a physical barrier, causing allele frequencies in different populations to drift apart (Allendorf and Phelps 1981; Mills and Allendorf 1996). We used microsatellite loci for our genetic analyses because they are highly variable, resulting in high power to distinguish between individuals and/or populations (Appendix 3 and 4).

\section{Genotyping}

In summary, the genotyping procedure was as follows: 1) extract DNA from tissue, 2) run the polymerase chain reaction (PCR) to amplify a nuclear microsatellite region of the DNA, 3) use gel electrophoresis to visualize and score alleles for each individual at each microsatellite locus. DNA was extracted using standard tissue protocols in the Dneasy Tissue Kit (Qiagen Inc.). Samples were left to digest overnight so that maximum product was obtained. 
Our goal was to run six microsatellite loci per species. For P. maniculatus, we used the six best amplifying primers for microsatellite loci from Chirhart et al. 2000 (Pml-1, 4, 5, 6, 10, and 12). Primers for C. gapperi and S. vagrans were not available, so primers developed for closely related species were used (see also Mech and Hallett 2001; Tallmon et al. 2002). Primers used for C. gapperi were designed by Gockel et al. (1997) for C. glareolus (MSCgl-4, MSCgl-15, and MSCgl-19) and by Ishibashi et al. (1995) for C. rufocanus (MSCRB-4, MSCRB-5, and MSCRB-6). Primers used for S. vagrans were developed by Maldonado (unpublished data) for S. ornatus. Out the 10 primer sequences that we tested, five amplified well in our S. vagrans samples: A3-5, A3-35, A4-20, A4-5, and SH-22. We also screened primers developed for the European common shrew (Sorex araneus) by Wyttenbach et al. (1997) and Balloux et al. (1998) but were unsuccessful in getting high quality, polymorphic product from any of these 13 primer sequences.

PCR products were separated in a $6.5 \%$ acrylamide gel for $2-2.5$ hours using the Li-cor Global IR ${ }^{2}$ System and visualized using Li-cor SAGA genotyping software (Licor, Inc. 2002). To ensure accuracy, gels were manually scored and compared to SAGA scores, and hand scores were double-checked by a second person. To facilitate scoring and allow comparisons between gels, we ran ladder and at least three positive controls (individuals run on each gel for that species at that locus) on each gel.

\section{Genetic Variation}

We first tested for genotypic differences between years with GENEPOP Internet Version 3.1c (Raymond and Rousset 1995) to evaluate whether or not we could pool data from 2000 and 2001 in order to maximize sample sizes and statistical power. We used a 
log-likelihood G-based exact test (Goudet et al. 1996), which estimates p-values using a Markov chain (Haldane 1954; Weir et al. 1990; Guo and Thompson 1992a). The values entered into the Markov chain were a dememorization number of 1000, with 1000 batches and 10,000 iterations per batch.

We calculated expected heterozygosity $\left(\mathrm{H}_{\mathrm{e}}\right.$ : based on Hardy-Weinberg proportions) and observed heterozygosity $\left(\mathrm{H}_{\mathrm{o}}\right)$ for each locus at each site, as well as allelic diversity (number of alleles) within GENEPOP Internet Version 3.1c (Raymond and Rousset 1995). Heterozygosity is equal to the proportion of individuals that are heterozygous at a given locus. If a locus is in $\mathrm{H}-\mathrm{W}$ equilibrium, $\mathrm{H}_{\mathrm{o}}$ should nearly equal $\mathrm{H}_{\mathrm{e}}$. Heterozygosity is important because it sets an upper limit on $\mathrm{F}_{\mathrm{ST}}$. Hedrick (1999) showed that $\mathrm{F}_{\mathrm{ST}}$ can never exceed the overall homozygosity $=[1$ - heterozygosity $]$, even if there is no gene flow between populations and they have completely different nonoverlapping sets of alleles. This is especially important for microsatellite loci, where heterozygosity may be quite high, and means that caution is required when comparing $\mathrm{F}_{\mathrm{ST}}$-values among studies that make use of markers with different levels of heterozygosity (Balloux et al. 2000; Balloux and Lugon-Moulin 2002).

We tested for Hardy-Weinberg and linkage disequilibrium (Appendix 5) using GENEPOP Internet Version 3.1c (Raymond and Rousset 1995). We used a two-way probability test entering the same values into the Markov Chain as noted above (Guo and Thompson $1992_{\mathrm{a}, \mathrm{b}}$ ). For H-W tests, a small p-value indicates that a locus may not be in $\mathrm{H}-\mathrm{W}$ proportions in a particular population. For linkage tests, a small p-value indicates that a locus pair may not be independent in a given population. To be conservative, we report all tests that resulted in $p<0.05$, but a certain number of significant tests are 
expected by chance, due to the large number of tests performed (one test per locus or locus pair per trapping grid). Therefore, we also include the results of a sequential Bonferroni procedure (Rice 1989).

\section{Gene Flow}

We analyzed gene flow using two measures: $\mathrm{F}_{\mathrm{ST}}$ and the assignment test (see Appendix 6 for details on both approaches). $\mathrm{F}_{\mathrm{ST}}$ is a measure of population subdivision that is calculated from allele frequencies of animals dispersed across a landscape (Wright 1951). Because $\mathrm{F}_{\mathrm{ST}}$ is the proportion of total genetic variation due to divergence among subpopulations, it is inversely related to the number of migrants per generation. $\mathrm{F}_{\mathrm{ST}}$ varies between zero and one, with higher numbers indicating more differentiation and less gene flow between populations. A number of different measures of genetic differentiation have been developed (for example: Wright 1931, 1951, 1969; CavalliSforza and Edwards 1967; Nei 1972; Weir and Cockerham 1984; Slatkin 1985; Chakraborty and Jin 1993; Goldstein et al. 1995a, b; Slatkin 1995; Shriver et al. 1997), but most make the same basic assumptions and yield the same kind of information, quantifying the distinctness of populations. We chose to use $\mathrm{F}_{\mathrm{ST}}$ because it has been used for many years to examine genetic divergence and gene flow, facilitating comparisons between studies, and because interpretation is straightforward. In addition, statistics developed specifically for microsatellites have performed poorly when fragmentation is more recent (Paetkau et al. 1997; Balloux and Lugon-Moulin 2002), as with highways. Our goal was to examine relative differences in $\mathrm{F}_{\mathrm{ST}}$, comparing genetic divergence between populations on the same side of highways to divergence between populations 
separated by highways. Therefore, our choice of measures was not of crucial importance, because we were more interested in relative differences within sites than in the actual value of $\mathrm{F}_{\text {Sт. }}$ In short, unlike most studies testing for genetic divergence, we had a control value (connectivity adjacent to highways) to compare to the treatment value (connectivity across highways), rather than relying entirely on a determination of what value of $\mathrm{F}_{\mathrm{ST}}$ should be considered "significant" for populations separated by a barrier (the highway).

The assignment test can provide insight into current gene flow by identifying likely migrants based on the multi-locus likelihood of their genotypes (Paetkau et al. 1995; Waser and Strobeck 1998). The assignment test assigns individuals to their populations of origin according to the likelihood of their genotypes occurring in each population. Misassignments provide an index of gene flow: a misassignment is an animal captured in one population, but assigned to another population because its genotype is more likely to come from the other population. A lower proportion of misassignments indicates less gene flow. (Note that some misassignments will arise as statistical artifacts, leading us to interpret relative differences in misassignments and not absolute levels). We compared misassignment rates between trapping grids on the same side of the highway to misassignment rates between grids separated by the highway.

We used GENEPOP Internet Version 3.1c (Raymond and Rousset 1995) to calculate $\mathrm{F}_{\mathrm{ST}}$ between population pairs using a weighted analysis of variance (Cockerham 1973; Weir and Cockerham 1984). For comparison, we report pairwise $\mathrm{F}_{\mathrm{ST}^{-}}$-values calculated using all loci, as well as those calculated using only those loci that were in Hardy-Weinberg equilibrium. We used GeneClass (Cornuet et al. 1999) to assign individuals to their most likely population of origin. We report misassignment rates 
calculated using two approaches: a likelihood-based test using Bayesian probabilities (Rannala and Mountain 1997), with and without loci deviating from H-W proportions, and a distance-based test that does not require $\mathrm{H}-\mathrm{W}$ or linkage equilibrium (Cornuet et al. 1999) using Nei’s D $D_{A}$ statistic (Nei 1987).

We first report misassignment rates obtained by considering only the most likely population of origin, where each individual was assigned to exactly one population. For animals that moved between trapping grids during our study, the capture population was defined as the population where the individual was first captured. Some individuals were only marginally more likely to come from one population than another, or were unlikely to come from any of the populations sampled; therefore, we also present misassignments that are more likely to represent true migrants (Proctor et al. In Press), using likelihood ratios of 10 (where a misassigned individual was at least 10 times more likely to come from the assigned population than from the population where it was captured), 20, and 100 as cutoff values. We used a distance-based assignment test (Nei's $\mathrm{D}_{\mathrm{A}}$ statistic), simulating 10,000 individuals, where the lower threshold for assignment was a probability of occurrence of 0.01 .

To help us calibrate the biological relevance of our estimates of gene flow across highways using the assignment test, we first estimated misassignment rates at the regional level (among sites) before proceeding with within site analyses. Because sites were 50 - $320 \mathrm{~km}$ apart $(30-200$ miles $)$, we knew that direct migration between these sites was impossible. Thus we expected a fairly high $\mathrm{F}_{\mathrm{ST}}$ value and a very low misassignment rate, theoretically, zero misassignments. 
Within sites, we treated trapping grids as populations and compared $\mathrm{F}_{\mathrm{ST}}$-values and misassignment rates between grids on the same side of highways (75 $\mathrm{m}$ apart) to values between grids separated by highways ( $75 \mathrm{~m}$ apart: Figure 3 ). For each site, our grid design gave us two values for grids on the same side, and two values for grids on opposite sides. To maintain equivalent distances between trapping grids when comparing gene flow adjacent to versus across highways, we only compared grids that were directly across the highway from one another (for example, we did not analyze gene flow between the NE and SW grids, or between the NW and SE grids, because the distances here were larger; Figure 3). Values reported for each site are means $(\mathrm{N}=2)$ for values between individual grids on the same side of the highway and those on opposite sides, as well as standard errors around the means. Finally, we averaged values for 2-lane sites and for 4-lane sites to facilitate comparisons based on highway width. The averaged data, comparing gene flow differences for voles, mice, and shrews at 2- versus 4-lane highways, are presented along with more detailed genetic data from each site. 


\section{Comparing gene flow adjacent to and across highways}

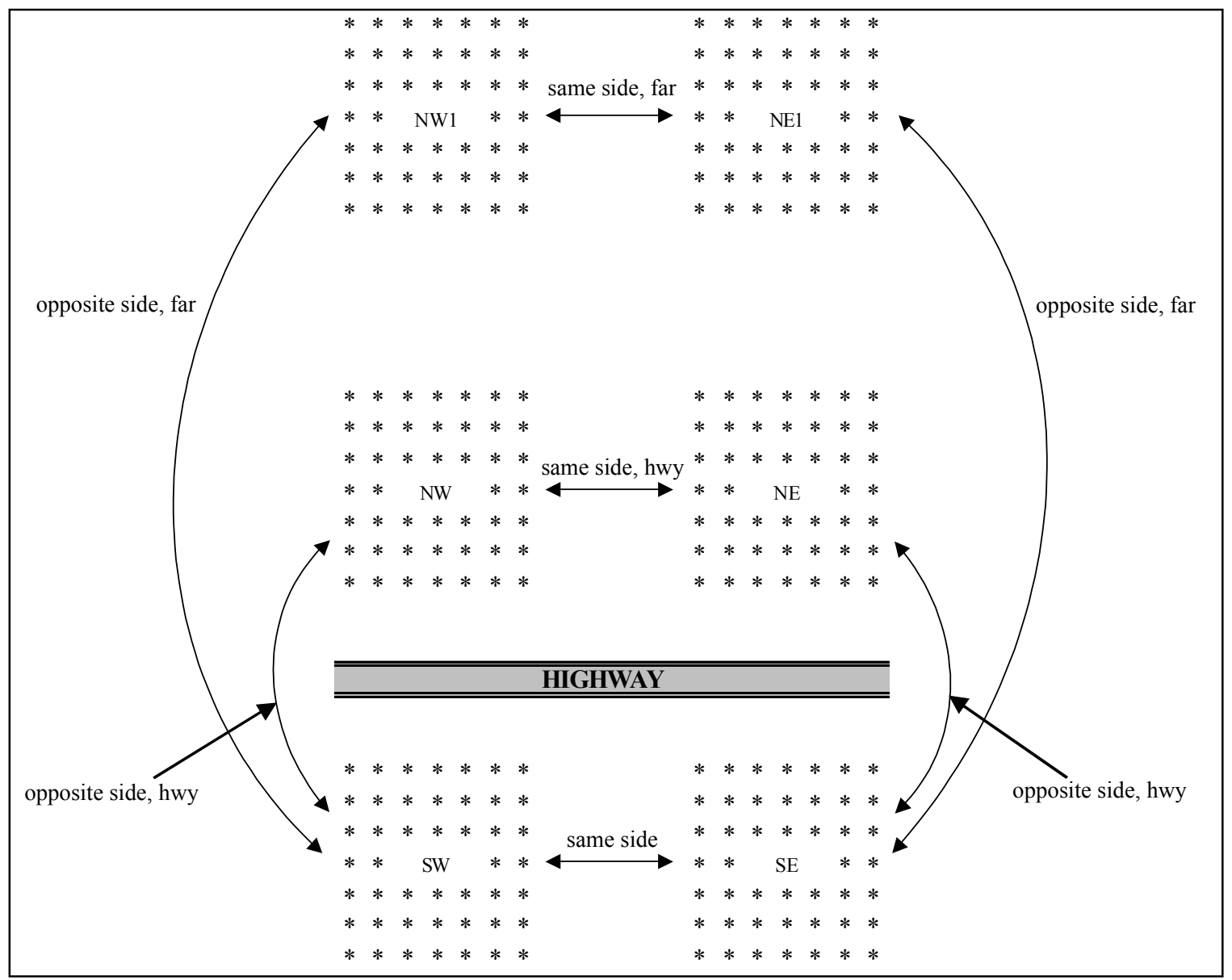

Figure 3. For clarity, grids are named as at Lubrecht and St. Regis. There were two ways to measure gene flow on the same side of (adjacent to) the highway (NE-NW and SE-SW) and two ways to measure gene flow on opposite sides of (across) the highway (NE-SE and NW-SW). Similarly for the forest interior, there were two ways to measure gene flow on the same side of the highway (NE1-NW1 and SE-SW) and two ways to measure gene flow on opposite sides of the highway (NE1-SE and NW1-SW). We compared gene flow adjacent to and across highways by averaging these $\mathrm{F}_{\mathrm{ST}}$-values and misassignment rates for individuals captured in grids on the same side of the highway ( $75 \mathrm{~m}$ apart), grids directly across the highway ( $75 \mathrm{~m}$ apart), and grids across the highway into the forest interior ( $240 \mathrm{~m}$ apart). We then averaged these values across sites to compare 2- and 4-lane highways for each species. 
As with $\mathrm{F}_{\mathrm{ST}}$-values, misassignments were "pairwise": in any given run, the assignment test had only two trapping grids from which to choose a population of origin (that in which the individuals were captured, plus the grid adjacent to or across the highway). If we had run the assignment test on whole sites at once, individuals might have been assigned to any of four (or six) trapping grids. As noted above, this would have compromised the balanced nature of the experimental design (equidistant trapping grids). Thus, misassignment rates are an index of movement, since an individual's true population of origin may not have been one of the two tested. In contrast, when using likelihood ratios to identify "true" migrants, individuals could be assigned to any trapping grid (or none), since an animal could legitimately have originated anywhere in the study area.

The presence of culverts within several sites may increase population connectivity across highways. It was not possible to explicitly test for the effects of culverts within this study (or to control for culverts by choosing only sites that lacked them), but within sites containing culverts, we do report $\mathrm{F}_{\mathrm{ST}}$ and misassignment values for grids connected by culverts and for grids lacking culverts, for the reader's comparison. Three of our sites contained culverts: Rainy Lake, St. Regis, and Tarkio. The culvert at Rainy Lake conducted a stream under the highway at the southern edge of our trapping grids, and was always flooded. St. Regis and Tarkio contained dry culverts. The culvert at St. Regis ran from the NW trapping grid into the median strip, but went no farther. The culvert at Tarkio did not open into our trapping grids, but ran under the highway within our site from a point south of our NE trapping grid to a point north of our SE trapping grid. 
By combining $\mathrm{F}_{\mathrm{ST}}$ and misassignment estimates with demographic analyses (see review by Mills et al. In Press), we maximized inference strength. In addition, we replicated both sites and trapping grids (populations) within sites. A third strength of the experimental design was the inclusion of controls (grids adjacent to highways) that we could compare to treatment (grids across highways) values. By choosing study sites nonrandomly, we sacrificed inference scope for inference strength. We eliminated from consideration sites with human development and sites where concrete barriers, railroad tracks, frontage roads, or rivers would have bisected the study area, because this would obviously have confounded our analyses of highway effects. Therefore, our scope of inference does not extend to such sites. However, if these types of obstructions influence population fragmentation in small mammals, they would be likely to magnify barrier effects of highways.

\section{RESULTS}

\section{Demography}

\section{Movement}

Over two summers we recorded 3,812 captures of 1,609 individuals of 15 different small mammal species (Appendix 7, Table 7.1). Deer mice were the species most often captured (504 individuals), followed by vagrant shrews (355 individuals), redbacked voles (318 individuals), red-tailed chipmunks (138 individuals), and yellow pine chipmunks (95 individuals). For those individuals that were marked and released, we averaged 2.6 captures per individual, ranging from one to 15 captures. Results for yellow pine and red-tailed chipmunks were similar, so they were pooled to simplify presentation. 
For all red-backed vole, deer mouse, and chipmunk data pooled, more marked animals moved adjacent to highways than across highways $\left(\chi^{2}=18.38 ; \mathrm{p}<0.001\right): 69$ animals moved adjacent to highways and 27 animals moved across highways. Some of these moved more than once, and most were deer mice. The only small mammals that crossed 4-lane highways were deer mice (with the exception of one male vole who permanently dispersed during fall or winter).

As predicted, there were fewer crossings of 4-lane highways than of 2-lane highways, and species differed in their response to highways (Figure 4). Logistic regression showed that species $(p=0.036)$ and highway width $(p=0.004)$ were significantly related to whether movement occurred adjacent to versus across the highway, while site $(\mathrm{p}=0.191)$, sex $(\mathrm{p}=0.624)$, and year $(\mathrm{p}=0.695)$ were not. Therefore, data for males and females in 2000 and 2001 were pooled among sites to examine differences among species at 2- and 4-lane highways. The demographic data suggest that forest-associated species (red-backed voles and chipmunks) were more inhibited by highways than habitat generalists (deer mice) (Figure 4; Appendix 7, Tables 7.2 and 7.3). Every time we saw an effect, it was in the expected direction: more movement adjacent to highways than across for red-backed voles and chipmunks at 2lane highways, and for deer mice and chipmunks at 4-lane highways. Unfortunately, our sample size of moving voles was too small to detect differences for voles at 4-lane sites. We observed only one vole and no chipmunks crossing 4-lane highways. 


\section{Percentage of individuals that moved}
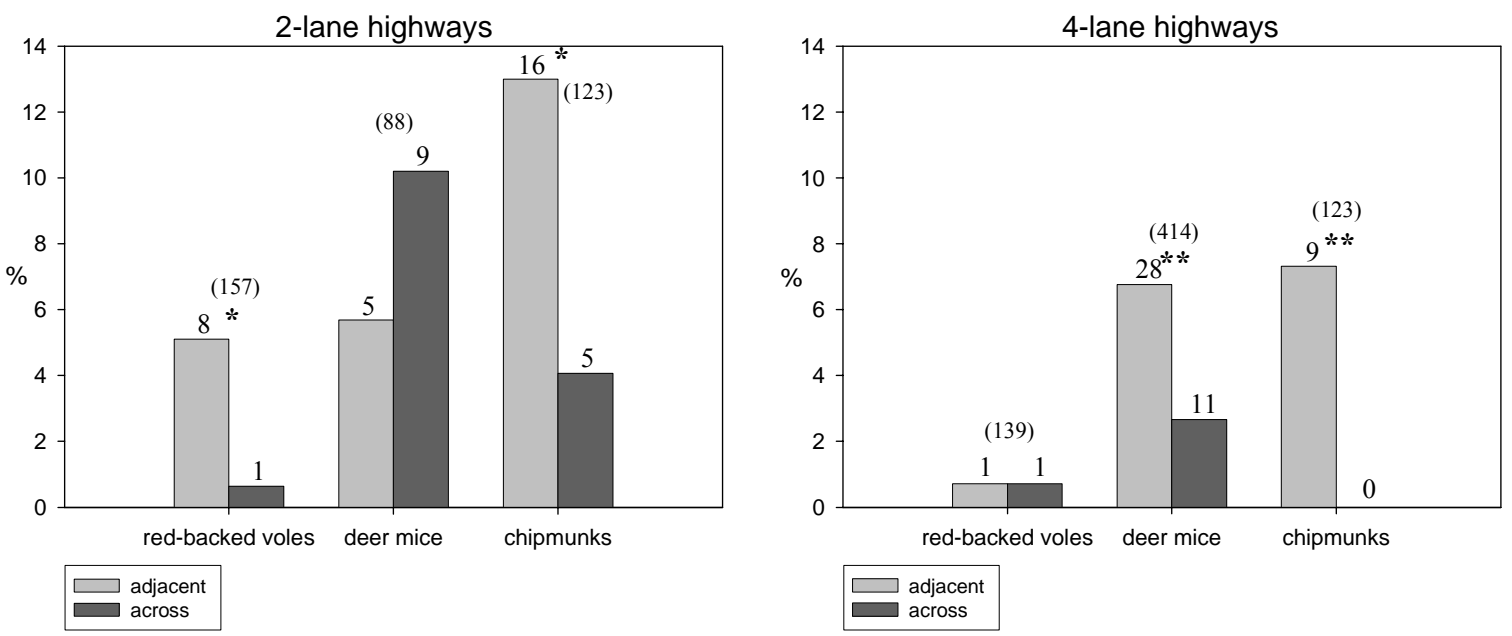

Figure 4. The numbers above the bars are the actual numbers of individuals that moved; the numbers in parentheses are the total captures. We tested for differences using a chi-square test, comparing observed movement to the null expectation of equal numbers of movements adjacent to and across highways. For example, $5 \%$ of the voles at 2 -lane sites moved adjacent to the highway, 8 of 157 captured.

$* \mathrm{p}<0.05 ; * * \mathrm{p}<0.01$

For all sites and years combined, $75 \%$ of the animals that moved between

trapping grids were male, but males did not move across the highway (as opposed to adjacent to the highway) proportionately more than females. In other words, not many females move, but those that do are just as likely to cross the highway as males. The preponderance of movements by males is not surprising, because dispersal is male-biased in many mammal species (Greenwood 1980; Wolff 1993; Lambin 1994; Petri et al. 1997; Bowne et al. 1999; Tallmon et al. 2002; but see Goertz 1964; Kozakiewicz 1976; Favre et al. 1997). 


\section{Abundance}

Deer mice were more abundant near highways than in the forest interior (Figure 5: Moran 2001), with no apparent relationship to vegetation patterns. Red-backed vole and chipmunk abundance appeared unrelated to either the presence of the highway or vegetation patterns. 

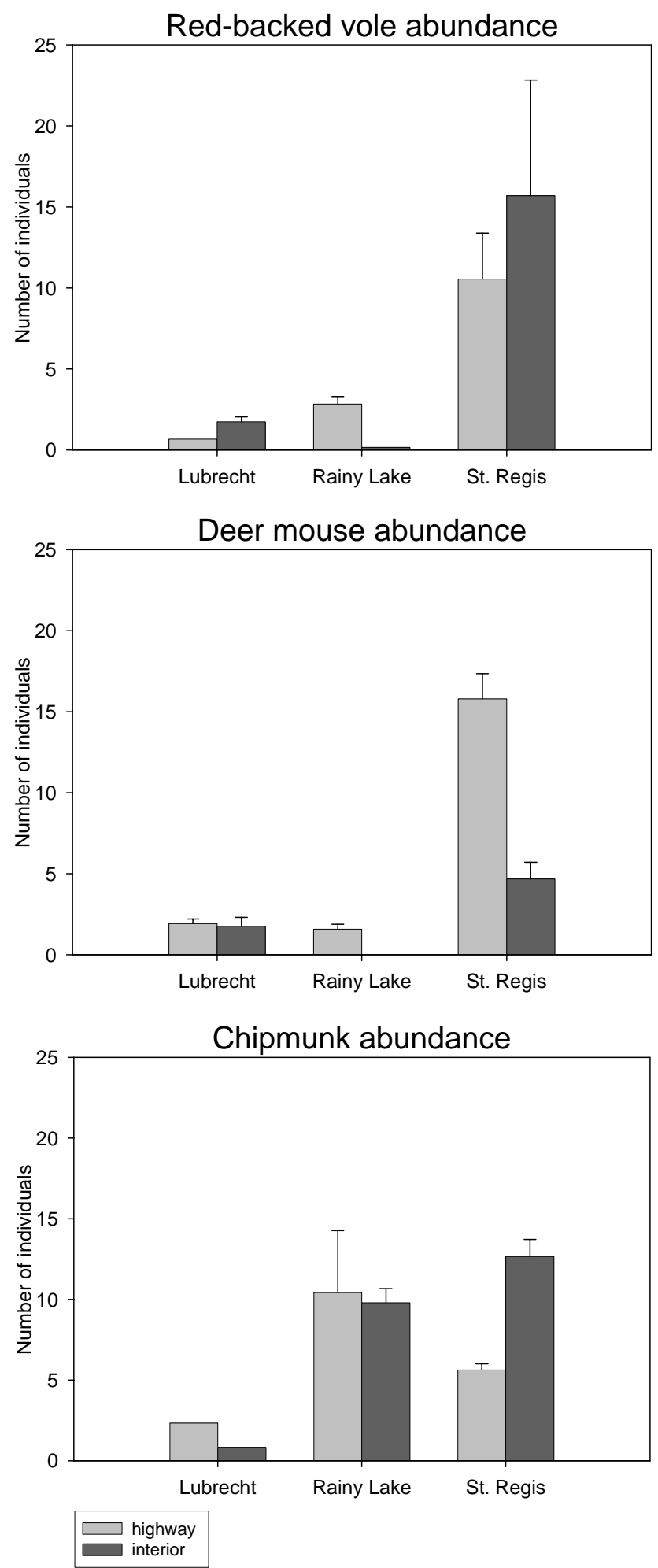

Figure 5. Average per grid abundance estimates were calculated using a Lincoln-Petersen estimator. These figures represent mean abundance, averaged over three 3-day trapping sessions during summer 2001, and include estimates from forest interior grids and only those highway grids adjacent to them (not grids across the highway). 


\section{Genetics}

We genotyped 314 red-backed voles at six microsatellite loci, 503 deer mice at six loci, and 355 vagrant shrews at five loci (Table 2). Sample sizes in the forest interior trapping grids were too small to analyze gene flow across highways, except at St. Regis, a 4-lane site. As determined by dentition, shrews from Lolo and St. Regis were almost all S. vagrans, but our sample from Lubrecht and Rainy Lake consisted of fairly equal numbers of $S$. vagrans and $S$. cinereus (masked shrews), as well as several S. monticolus (montane shrews). For shrews with extremely worn teeth, such that species determination was uncertain, if the genotype included unusual alleles (suggesting that they were unlikely to be $S$. vagrans), the individuals were excluded from further analysis.

\section{Sample size for genetic analyses}

\begin{tabular}{|l|c|c|c|c|c|c|}
\hline \multirow{4}{*}{ RB voles } & \multicolumn{3}{|c|}{ 2-lane } & \multicolumn{2}{c|}{ 4-lane } & Total \\
\cline { 2 - 7 } & Lolo & Lubrecht & Rainy & St. Regis & Tarkio & \\
\cline { 2 - 7 } Deer mice & 32 & 52 & 79 & 151 & - & 314 \\
Vagrant shrews & $13^{*}$ & 45 & $29 *$ & $178^{* *}$ & $238^{* *}$ & 503 \\
\hline
\end{tabular}

Table 2. Number of individuals that were genotyped does not necessarily equal the total number captured, since not all individuals amplified well. Not all species occurred at all sites. * Sample sizes were too low to analyze mouse gene flow at Lolo (mice captured on only one side of the highway) and Rainy Lake (only two mice from northern grids). ${ }^{* *}$ Samples from 2000 and 2001 were pooled, except that data for deer mice from St. Regis and Tarkio were not pooled. These mice were treated as separate populations: 46 mice in St. Regis 2000, 132 in St. Regis 2001, 81 in Tarkio 2000, and 157 in Tarkio 2001. *** Shrew numbers were quite low at Lubrecht (most were not S. vagrans), and thus were not analyzed.

\section{Testing Assumptions}

Red-backed voles: We tested for genotypic differences between years and found that out of six loci and four sites $(6 * 4=24$ tests $)$, there were two instances of differences between years: one locus at Lubrecht and one locus at St. Regis. After a sequential 
Bonferroni procedure was run, none remained significant with "table-wide" $\alpha=0.05$. Therefore, we pooled 2000 and 2001 samples for all analyses that follow.

Among individual trapping grids, tests for Hardy-Weinberg proportions found several departures: locus 4 (2/17 tests), locus 5 (1/17 tests), locus 15 (2/17 tests), locus 6 (4/17 tests), and locus 4B (2/17 tests). After a sequential Bonferroni procedure, several departures remained: locus 15 (1/17 tests), locus 6 (4/17 tests), and locus 4B (1/17 tests). Thus, we were mainly concerned about locus 6 . We report $\mathrm{F}_{\mathrm{ST}}$-values and misassignment rates calculated with and without locus 6 .

Linkage disequilibrium was detected in $9 \%$ of tests (21/227 tests), and in just $4 \%$ of tests ( $9 / 227$ tests) after a sequential Bonferroni correction for multiple comparisons. No locus pair was consistently found to be in linkage disequilibrium across populations; no pairs were detected more than three times (no more than once after Bonferroni correction).

Deer mice: We tested for genotypic differences between years and found that out of six loci and three sites ( $6 * 3=18$ tests), $13 / 18$ tests suggested differences: four loci at Lubrecht and Tarkio, and five loci at St. Regis. After a sequential Bonferroni procedure, 10/18 remained significant: two loci at Lubrecht, five at St. Regis, and three at Tarkio. Due to low sample sizes at Lubrecht, we pooled data from 2000 and 2001. However, for the purposes of within site analyses of highway effects, we considered St. Regis 2000/2001 and Tarkio 2000/2001 to be four separate populations.

We found a number of departures from H-W proportions: locus 1 (17/22 tests), locus 6 (8/22 tests), locus 4 (6/22 tests), locus 5 (6/22 tests), locus 10 (19/22 tests) and locus 12 (4/22 tests). After a sequential Bonferroni correction, several deviations from 
H-W equilibrium remained: locus 1 (15/22 tests), locus 6 (4/22 tests), locus 4 (3/22 tests), locus 5 (3/22 tests), locus 10 (19/22 tests) and locus 12 (2/22 tests). Because loci 1 and 10 were especially problematic, we analyzed gene flow with and without these loci.

Linkage disequilibrium was detected in $33 \%$ of tests (86/261 tests), and in $24 \%$ of tests $(63 / 261$ tests) after a sequential Bonferroni correction for multiple comparisons. Linkage was particularly high at St. Regis 2001 and Tarkio 2001 (36 and 68\%, respectively, 30 and 53\% after Bonferroni correction), where sample sizes were high and many family groups may have been sampled; these sites experienced a large recruitment event that summer, and many young mice were captured, sometimes two or three to a trap. No locus pair was consistently found to be in linkage disequilibrium across populations, except for 4 and 5, which were in disequilibrium $75 \%$ of the time ( $63 \%$ of the time after Bonferroni correction). We investigated the effect of linkage disequilibrium on gene flow estimates by comparing results from a distance-based assignment test (which does not assume linkage equilibrium) to results from the Bayesian assignment procedure.

Vagrant shrews: We tested for genotypic differences between years and found that out of five loci and three sites $(5 * 3=15$ tests), $7 / 15$ tests suggested differences: one locus at Lolo, five loci at Rainy Lake (all loci), and one locus at St. Regis. After a sequential Bonferroni procedure, 6/15 remained significant, those for Rainy Lake and St. Regis. Differences at Rainy Lake are most likely a result of differences in sample sizes between years: because we captured only five shrews in 2000 and 21 shrews in 2001, allele and genotype frequencies are almost certainly different. Given this explanation, it made sense to pool data from 2000 and 2001, and sample size at Rainy Lake was too 
small to do otherwise. A3-35 was the only locus that fluctuated between years at more than one site, so data were pooled

Among individual trapping grids, tests for $\mathrm{H}-\mathrm{W}$ proportions revealed several departures: locus A3-5 (10/12 tests), locus SH-22 (7/12 tests), locus A4-5 (3/12 tests), and locus A3-35 (1/12 tests). After a sequential Bonferroni procedure, only A3-5 and SH-22 deviated from H-W proportions (only 1/12 tests for A4-5 remained significant). Thus, we were mainly concerned about locus A3-5 and SH-22 and report $\mathrm{F}_{\mathrm{ST}^{-}}$-values and misassignment rates calculated with and without these loci.

Linkage disequilibrium was detected in just $4 \%$ of tests ( $4 / 109$ tests), and in $<1 \%$ of tests (1/109 tests) after a sequential Bonferroni correction for multiple comparisons. Although linkage appears to be less of a concern for shrews than for voles or mice, there may be weak linkage between A3-5 and A4-20, as this pair was in disequilibrium in 27\% of tests (3/11 tests) before the Bonferroni procedure.

Details are reported in Appendix 8.

\section{Genetic Variation}

Genetic variation at microsatellite loci was quite high for all three species (Appendix 9). Averaging across sites and loci, expected heterozygosity ranged from $0.762-0.816$ for voles, $0.899-0.909$ for mice, and $0.858-0.874$ for shrews, depending on whether loci out of Hardy-Weinberg proportions were included in the calculation. When loci that deviated from $\mathrm{H}-\mathrm{W}$ proportions were removed, heterozygosity increased somewhat and observed heterozygosity $\left(\mathrm{H}_{\mathrm{o}}\right)$ more closely resembled expected heterozygosity $\left(\mathrm{H}_{\mathrm{e}}\right)$. Due to high heterozygosities, the upper bound on $\mathrm{F}_{\mathrm{ST}}$ was 
constrained to be rather low: $0.184-0.234$ for voles, $0.091-0.101$ for mice, and $0.126-$ 0.142 for shrews, again dependent upon which loci were used to compute $\mathrm{F}_{\mathrm{ST}}$. This should be kept in mind when comparing $\mathrm{F}_{\mathrm{ST}}$ values from this study to those from other studies.

Heterozygosity did not vary much from site to site, in spite of large differences in sample size. Nor did the mean number of alleles per locus, which like heterozygosity values, tended to be rather high. This is probably an indication that overall population sizes in the region were high. Our trapping grids were situated within large blocks of contiguous forest, but we sampled only those individuals that were captured in our grids. Allelic diversity ranged from four alleles at vole locus 4B (Lubrecht) to 38 alleles at mouse locus 6 (Tarkio). The mean number of alleles per locus per site was 12.2 for voles, 19.7 for mice, and 14 for shrews. Heterozygosity and allelic diversity are presented in more detail in Appendix 9.

\section{Gene Flow}

Differences among sites: At the regional level (among sites), $\mathrm{F}_{\mathrm{ST}}$ averaged 0.035 for voles, 0.048 for mice, and 0.029 for shrews, regardless of whether loci out of H-W equilibrium were included (Table 3; Appendix 10). The percentage of individuals correctly assigned to their population of capture averaged $70 \%$ for voles, $88 \%$ for deer mice, and $75 \%$ for shrews. None of the misassignments represent true migrants, because sites were 50 - $320 \mathrm{~km}(30$ - 200 miles $)$ apart and small mammals do not disperse over such large distances. These results indicate that for our within site comparisons, we will focus on relative differences adjacent to versus across highways instead of on absolute 
values, because many misassignments are statistical, not actual, migrants. We reduced spurious misassignments (statistical migrants) by using a likelihood ratio of 10,20 , or 100 as a cutoff value: the percentage of individuals correctly assigned was $>99 \%$ among sites for voles and shrews and $>96 \%$ for mice (Appendix 10: Table 10.7).

Genetic differences among sites

\begin{tabular}{|l|r|r|r|r|r|r|}
\hline & \multicolumn{2}{|c|}{ Voles } & \multicolumn{2}{c|}{ Mice } & \multicolumn{2}{c|}{ Shrews } \\
\hline Loci analyzed (test) & $\mathrm{F}_{\mathrm{ST}}$ & assign & $\mathrm{F}_{\mathrm{ST}}$ & assign & $\mathrm{F}_{\mathrm{ST}}$ & assign \\
\hline all loci (Bayesian) & 0.043 & 0.742 & 0.047 & 0.893 & 0.028 & 0.772 \\
less 1 locus (Bayesian) & 0.035 & 0.691 & 0.046 & 0.889 & 0.029 & 0.761 \\
less 2 loci (Bayesian) & $\mathrm{n} / \mathrm{a}$ & $\mathrm{n} / \mathrm{a}$ & 0.048 & 0.885 & 0.029 & 0.755 \\
all loci (Nei $\mathrm{D}_{\mathrm{A}}$ ) & $\mathrm{n} / \mathrm{a}$ & 0.704 & $\mathrm{n} / \mathrm{a}$ & 0.867 & $\mathrm{n} / \mathrm{a}$ & 0.749 \\
\hline
\end{tabular}

Table 3. Genetic differentiation across the study region in western Montana was rather low. Averages for pairwise $\mathrm{F}_{\mathrm{ST}}$-values among sites and for the proportion of individuals correctly assigned are shown. Misassignments cannot be actual migrants, since sites were $50-320 \mathrm{~km}(30-200$ miles $)$ apart. $\mathrm{F}_{\mathrm{ST}}$ was calculated with and without loci that deviated from Hardy-Weinberg proportions. The likelihood-based Bayesian assignment test was used with and without loci that deviated from $\mathrm{H}-\mathrm{W}$ proportions, and the distance-based assignment test (Nei's $\mathrm{D}_{\mathrm{A}}$ distance statistic), which does not assume $\mathrm{H}-\mathrm{W}$ equilibrium, was used with all loci. Choice of methods, with or without loci not in $\mathrm{H}-\mathrm{W}$ equilibrium, had little effect on these results.

The exclusion of loci that deviated from Hardy-Weinberg proportions had little effect on results, nor did the choice of assignment methods. This was true within sites, as well as between sites. Therefore, values reported in the text are for $\mathrm{F}_{\mathrm{ST}}$ calculated only with those loci in $\mathrm{H}-\mathrm{W}$ proportions, and for misassignment rates calculated using the distance-based test using Nei's $\mathrm{D}_{\mathrm{A}}$ distance statistic (a conservative approach, particularly appropriate for deer mice where linkage was relatively frequent). Full matrices showing pairwise $\mathrm{F}_{\mathrm{ST}}$-values and misassignment rates between sites are located in Appendix 10.

Gene flow within sites: Relative differences in gene flow adjacent to highways versus across highways were largest for vagrant shrews, variable for deer mice, and insignificant for red-backed voles. Effect size varied widely among sites (Figure 6). 


\section{Gene flow at 2-lane highways}

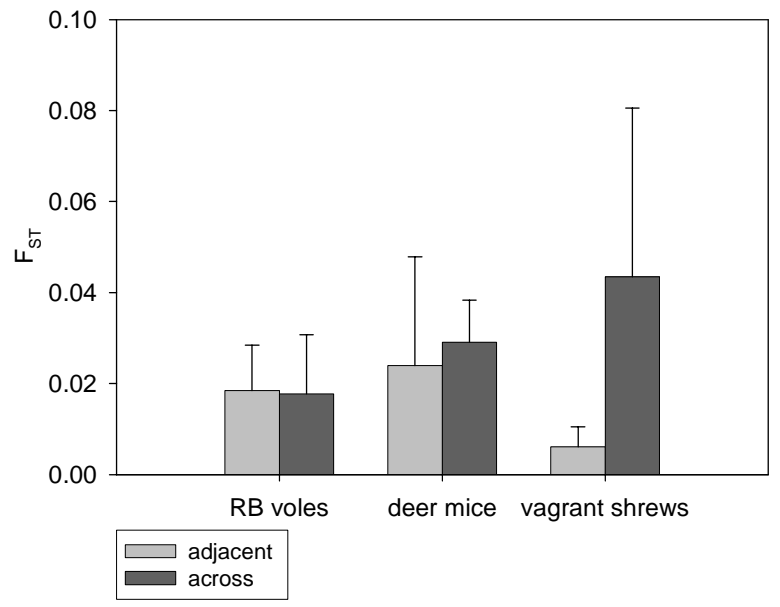

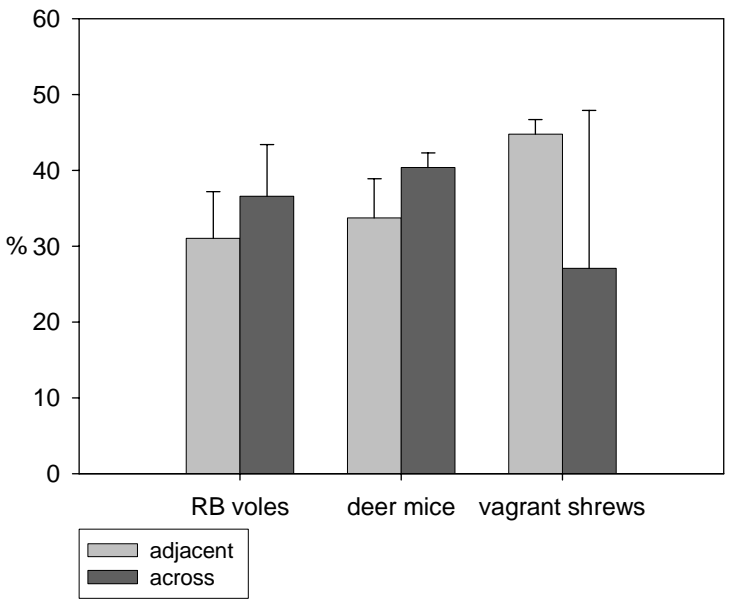

Figure 6a. Gene flow at 2-lane highways was reduced for vagrant shrews only (higher $\mathrm{F}_{\mathrm{ST}}$ and lower misassignment rate across highways). We compared grids on the same side of the highway (75 $\mathrm{m}$ apart) to grids on opposite sides of the highway (75 m apart) to show no isolation by distance. Numbers of comparisons (grids adjacent versus grids across) are in parentheses. $\mathrm{F}_{\mathrm{ST}^{-}}$-values were calculated using only those loci that were in Hardy-Weinberg proportions. Misassignment rates were calculated using a distancebased test based on Nei's $\mathrm{D}_{\mathrm{A}}$ distance statistic.

\section{Gene flow at 4-lane highways}

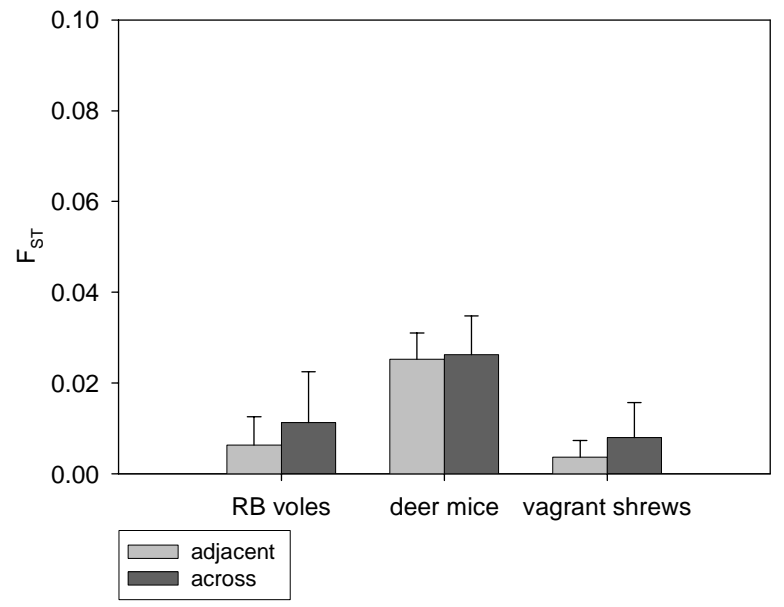

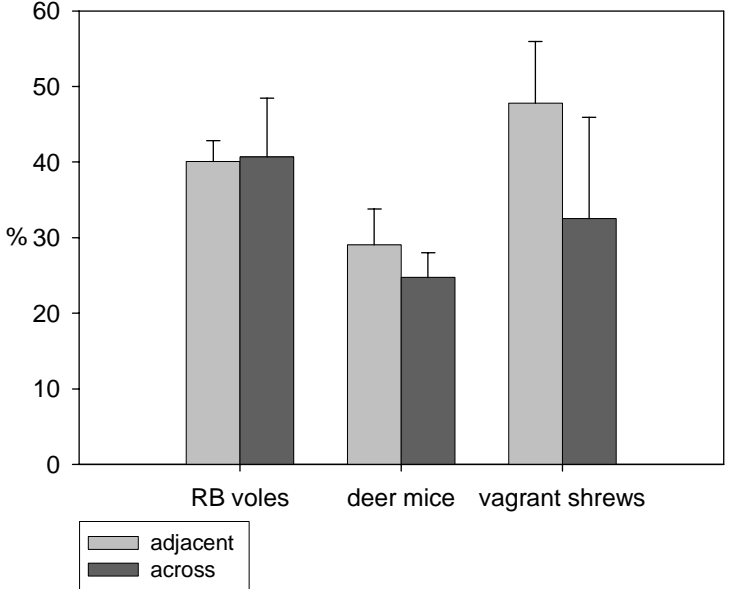

Figure $6 \mathrm{~b}$. Gene flow at 4-lane highways was reduced for deer mice and vagrant shrews (higher $\mathrm{F}_{\mathrm{ST}}$ and lower misassignment rate across highways). We compared grids on the same side of the highway ( $75 \mathrm{~m}$ apart) to grids on opposite sides of the highway ( $75 \mathrm{~m}$ apart) to show no isolation by distance. Numbers of comparisons (grids adjacent versus grids across) are in parentheses. $\mathrm{F}_{\mathrm{ST}^{-}}$-values were calculated using only those loci that were in Hardy-Weinberg proportions. Misassignment rates were calculated using a distancebased test based on Nei's $\mathrm{D}_{\mathrm{A}}$ distance statistic. 
Vole gene flow was not reduced across highways (Figures 6 and 7; Appendix 11). Within sites, voles appeared to form one large panmictic (randomly mating) population. However, the number of migrants across highways sampled over two summers (as determined by the assignment test) was rather low: across sites, the average ranged from zero to three migrants, depending on the likelihood ratio (LR) used as a cutoff value, above which individuals were considered "true" migrants (Table 4).

\section{Gene flow for red-backed voles}
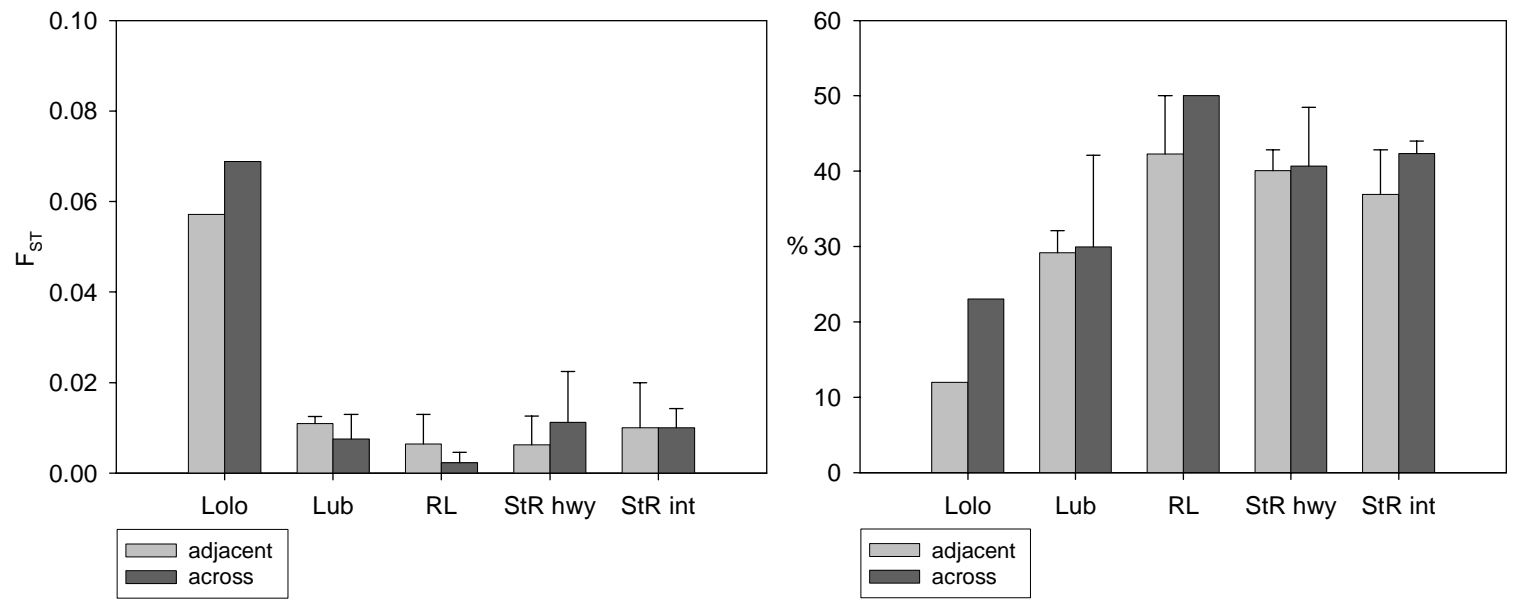

Figure 7. Gene flow in red-backed voles did not appear to be influenced by highways. We compared genetic differences between animals captured on the same side of the highway (75 m apart), versus those captured on opposite sides of the highway ( $75 \mathrm{~m}$ apart). Numbers of comparisons (grids adjacent versus grids across) are in parentheses. $\mathrm{F}_{\mathrm{ST}^{-}}$-values were calculated using only those loci that were in HardyWeinberg proportions. Misassignment rates were calculated using a distance-based test based on Nei's $D_{A}$ distance statistic. Lolo, Lubrecht, and Rainy Lake are 2-lane highway sites, while St. Regis is a 4-lane highway site. At St. Regis in 2001, we made comparisons directly across the highway (75 m) and across the highway into the forest interior $(240 \mathrm{~m})$. 
Number of red-backed vole migrants detected across highways

\begin{tabular}{|l|r|r|r|r|}
\hline & $\begin{array}{r}\text { Migrants } \\
\text { LR } \geq \mathbf{1 0}\end{array}$ & $\begin{array}{r}\text { Migrants } \\
\text { LR } \geq \mathbf{2 0}\end{array}$ & $\begin{array}{r}\text { Migrants } \\
\text { LR } \geq \mathbf{1 0 0}\end{array}$ & $\begin{array}{r}\text { Total } \\
\text { Analyzed }\end{array}$ \\
\hline Lolo & $1(3.2 \%)$ & $1(3.2 \%)$ & 0 & 31 \\
Lubrecht & $4(8.5 \%)$ & $4(8.5 \%)$ & 0 & 47 \\
Rainy Lake & $2(2.6 \%)$ & $2(2.6 \%)$ & 0 & 78 \\
St. Regis: hwy & $3(2.9 \%)$ & 0 & 0 & 102 \\
St. Regis: far & $5(6.5 \%)$ & $3(3.9 \%)$ & 0 & 77 \\
\hline
\end{tabular}

Number of deer mouse migrants detected across highways

\begin{tabular}{|l|r|r|r|r|} 
& $\begin{array}{r}\text { Migrants } \\
\text { LR } \geq \mathbf{1 0}\end{array}$ & $\begin{array}{r}\text { Migrants } \\
\text { LR } \geq \mathbf{2 0}\end{array}$ & $\begin{array}{r}\text { Migrants } \\
\text { LR } \geq \mathbf{1 0 0}\end{array}$ & $\begin{array}{r}\text { Total } \\
\text { Analyzed }\end{array}$ \\
\hline Lubrecht & $2(5.1 \%)$ & $2(5.1 \%)$ & $2(5.1 \%)$ & 39 \\
St. Regis: hwy & $14(8.5 \%)$ & $12(7.3 \%)$ & $9(5.5 \%)$ & 164 \\
St. Regis: far & $1(1.3 \%)$ & $1(1.3 \%)$ & 0 & 80 \\
Tarkio & $16(6.7 \%)$ & $11(4.6 \%)$ & $7(2.9 \%)$ & 238 \\
\hline
\end{tabular}

Number of vagrant shrew migrants detected across highways

\begin{tabular}{|l|r|r|r|r|} 
& Migrants & Migrants & Migrants & Total Analyzed \\
LR $\geq \mathbf{1 0}$ & LR $\geq \mathbf{2 0}$ & 100 & \\
\hline Lolo & $5(5.2 \%)$ & $1(1.0 \%)$ & $1(1.0 \%)$ & 97 \\
Rainy Lake & $1(3.8 \%)$ & $1(3.8 \%)$ & $1(3.8 \%)$ & 26 \\
St. Regis: hwy & $6(3.2 \%)$ & $3(1.6 \%)$ & $1(0.5 \%)$ & 190 \\
St. Regis: far & $4(3.3 \%)$ & $3(2.5 \%)$ & $2(1.7 \%)$ & 121 \\
\hline
\end{tabular}

Table 4. Migrants were identified by the assignment test, using a distance-based procedure based on Nei's $\mathrm{D}_{\mathrm{A}}$ distance statistic. These individuals were assigned to a population across the highway from their population of capture, with odds of 10:1, 20:1, and 100:1 of originating in the assigned population versus the capture population. Migrants moved a minimum of $75 \mathrm{~m}$ across highways, except that migrants between the forest interior and the opposite side of the highway (St. Regis: far) moved a minimum of 240 $\mathrm{m}$. This is an index of movement across highways over two years (except that the forest interior was sampled only in 2001), and the actual number of migrants (some probably went unsampled) may be higher. We do not show the number of migrants per year, because individuals may have migrated across highways at any time prior to initial capture; we do not show the number of migrants per generation, because of the uncertainly involved in estimating generation time. Lolo, Lubrecht, and Rainy Lake are 2-lane sites; St. Regis and Tarkio are 4-lane sites.

Deer mouse gene flow was reduced by 4-lane highways, only at St. Regis

(Figures 6 and 8; Appendix 11). Gene flow, as measured by $\mathrm{F}_{\mathrm{ST}}$ and misassignment rates, was similar between the forest interior and the opposite side of the highway (240 m), versus between grids separated only by the highway $(75 \mathrm{~m})$. This seems to indicate that it is the presence of the highway itself that decreases gene flow, and not distance, but 
when likelihood ratios were used to identify real migrants, the difference was quite large: for $L R=10$ there were 14 migrants directly across the highway versus only one migrant between the interior and opposite side of the highway. Gene flow differences across the 4-lane highway were apparent at St. Regis, but not at Tarkio. Both the number of "true" migrants and the proportion of migrants per site were higher, on average, for mice than for voles or shrews, ranging from six to 11 migrants across highways (Table 4). Due to particularly high levels of genetic variation in deer mice (Appendix 9), some alleles were unique to some sites (and to some trapping grids), resulting in higher accuracy in the assignment test than was achieved for voles or shrews. There was less impact on $\mathrm{F}_{\text {ST }}$, because $\mathrm{F}_{\mathrm{ST}}$ does not consider allele identity when measuring proportional variation.

\section{Gene flow for deer mice}

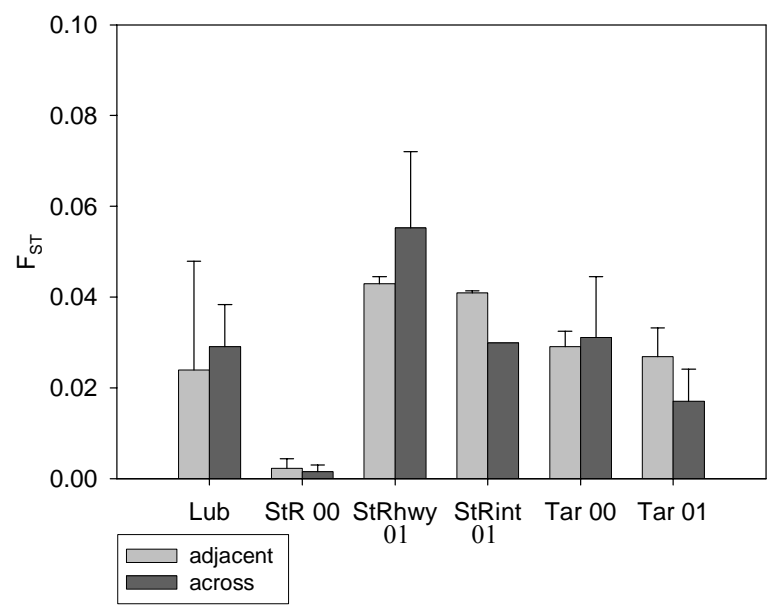

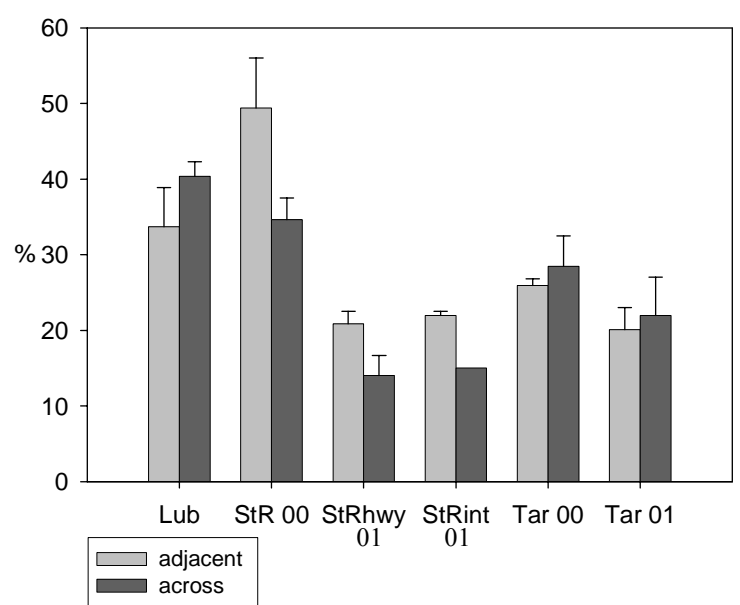

Figure 8. Gene flow in deer mice was reduced by 4-lane highways only, and only at St. Regis (higher $\mathrm{F}_{\mathrm{ST}}$ except for St. Regis highway grids in 2001- and lower misassignment rate across highways). We compared genetic differences between animals captured on the same side of the highway ( $75 \mathrm{~m}$ apart), versus those captured on opposite sides of the highway (75 m apart). Numbers of comparisons (grids adjacent versus grids across) are in parentheses. $\mathrm{F}_{\mathrm{ST}}$-values were calculated using only those loci that were in HardyWeinberg proportions. Misassignment rates were calculated using a distance-based test based on Nei's $\mathrm{D}_{\mathrm{A}}$ distance statistic. Lubrecht is a 2-lane highway site, while St. Regis and Tarkio are 4-lane highway sites. At St. Regis in 2001, we made comparisons directly across the highway $(75 \mathrm{~m})$ and across the highway into the forest interior $(240 \mathrm{~m})$. 
Unlike voles and deer mice, shrew gene flow was reduced across both 2- and 4lane highways (but only at one of two 2-lane sites), and the relative differences adjacent to versus across highways were large (Figures 6 and 9; Appendix 11). Gene flow was reduced most severely at Rainy Lake, where relative differences in $\mathrm{F}_{\mathrm{ST}}$-values adjacent to versus across the highway were almost an order of magnitude greater than $\mathrm{F}_{\mathrm{ST}}$ differences at the other two sites. This was also reflected in the misassignment rates, which showed a $37 \%$ decrease across highways at Rainy Lake, compared to no difference at Lolo and a $15 \%$ decrease at St. Regis. As was the case with deer mice, data from St. Regis show that the presence of the highway is more important than distance in reducing gene flow, because the $\mathrm{F}_{\mathrm{ST}}$-values and misassignment rates are similar between the south side of the highway and the north side of the highway $(75 \mathrm{~m})$, and between the south side of the highway and the forest interior on the north side $(240 \mathrm{~m})$. The number of "true" migrants across highways within sites ranged from one to four shrews, depending on the LR that was specified (Table 4). 


\section{Gene flow for vagrant shrews}

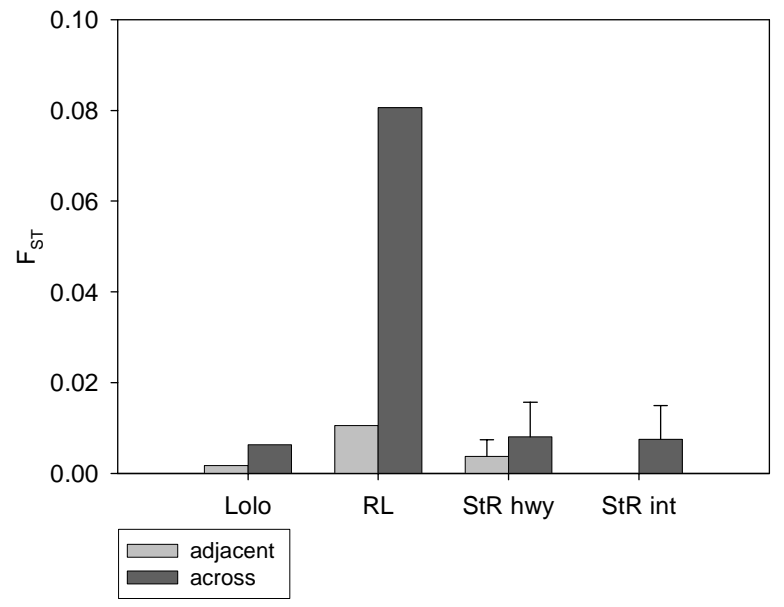

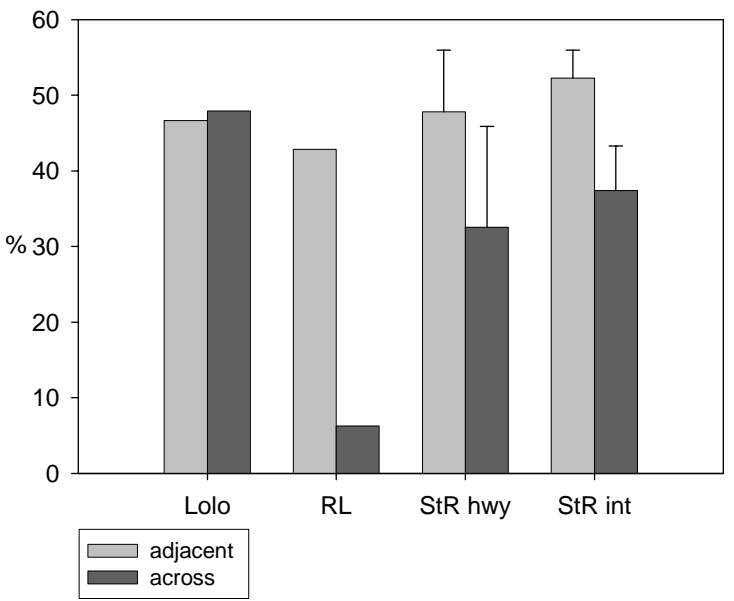

Figure 9. Gene flow in vagrant shrews was reduced by both 2-lane (at Rainy Lake only) and 4-lane highways (higher $\mathrm{F}_{\mathrm{ST}}$ and lower misassignment rate across highways). We compared genetic differences between animals captured on the same side of the highway ( $75 \mathrm{~m}$ apart), versus those captured on opposite sides of the highway (75 m apart). Numbers of comparisons (grids adjacent versus grids across) are in parentheses. $\mathrm{F}_{\mathrm{ST}}$-values were calculated using only those loci that were in Hardy-Weinberg proportions. Misassignment rates were calculated using a distance-based test based on Nei's $\mathrm{D}_{\mathrm{A}}$ distance statistic. Lolo and Rainy Lake are 2-lane highway sites, while St. Regis is a 4-lane highway site. At St. Regis in 2001, we made comparisons directly across the highway $(75 \mathrm{~m})$ and across the highway into the forest interior (240 $\mathrm{m})$. 
Culverts may promote movement across highways for vagrant shrews and deer mice (Table 5). Shrews at St. Regis, where a culvert connected the NW grid to the median strip, showed the largest differences between grids partially connected by the culvert and adjacent grids lacking a culvert: $\mathrm{F}_{\mathrm{ST}}$ decreased by 0.015 and the misassignment rate increased by $27 \%$ near the culvert. Mice at St. Regis (both years) also exhibited lower $\mathrm{F}_{\mathrm{ST}}$-values and higher misassignment rates in grids partially connected by the culvert. However, the culvert at Tarkio, which did not open directly into our trapping grids, did not appear to influence $\mathrm{F}_{\mathrm{ST}}$-values or misassignment rates between grids near the culvert. Nor did voles at Rainy Lake (where the culvert was permanently flooded) or St. Regis seem to benefit from culverts.

\section{Effect of culverts on gene flow}

\begin{tabular}{|l|r|r|r|r|c|}
\hline Species and site & \multicolumn{2}{|c|}{ Nearer culvert } & \multicolumn{2}{|r|}{ Farther from culvert } & Effect? \\
\hline Voles: Rainy 2-ln (wet) & 0.002 & 0.500 & 0.002 & 0.500 & $\mathrm{~N}$ \\
Voles: St. Regis 4-ln & 0.023 & 0.329 & 0.000 & 0.485 & $\mathrm{~N}$ \\
Mice: St. Regis 2000 4-ln & 0.000 & 0.375 & 0.003 & 0.318 & $\mathrm{Y} ?$ \\
Mice: St. Regis 2001 4-ln & 0.038 & 0.167 & 0.072 & 0.114 & $\mathrm{Y}$ \\
Mice: Tarkio 2000 4-ln & 0.045 & 0.244 & 0.018 & 0.325 & $\mathrm{~N}$ \\
Mice: Tarkio 2001 4-ln & 0.010 & 0.169 & 0.024 & 0.270 & $\mathrm{~N}$ \\
Shrews: St. Regis 4-ln & 0.000 & 0.459 & 0.016 & 0.191 & $\mathrm{Y}$ \\
\hline
\end{tabular}

Table 5. Culverts may promote movement across highways for deer mice and vagrant shrews. We compared $\mathrm{F}_{\mathrm{ST}}$-values (calculated with only those loci in $\mathrm{H}-\mathrm{W}$ proportions) and misassignment rates (distance-based test) between trapping grids that contained openings to culverts or were near openings, to values between adjacent trapping grids that were not connected by culverts. If culverts facilitated gene flow, we expected lower $\mathrm{F}_{\mathrm{ST}}$-values and higher misassignment rates nearer to the culvert. Three sites contained culverts, but the culvert at St. Regis was the only dry culvert that opened directly into our trapping grids. 


\section{DISCUSSION}

Movement was reduced across highways as predicted, more so for 4-lane than for 2-lane highways (Table 6). Species responded differently to highways. We predicted that red-backed voles, strong forest-associates, would be the species most severely affected by highways, followed by chipmunks (also forest-associates), vagrant shrews (more generalist but associated with mesic areas and undergrowth), and deer mice (adaptable habitat generalists). The support for these predictions varied, and a fenceeffect (leading to higher abundance near highways) seems likely only for deer mice (but alternative explanations cannot be excluded).

\section{Do highways reduce small mammal movement?}

\begin{tabular}{|l|c|c|c|c|c|c|c|c|}
\hline & \multicolumn{2}{|c|}{ RB voles } & \multicolumn{2}{c|}{ Deer mice } & \multicolumn{2}{c|}{ Chipmunks } & \multicolumn{2}{c|}{ Vagrant shrews } \\
\cline { 2 - 9 } & 2-lane & 4-lane & 2-lane & 4-lane & 2-lane & 4-lane & 2-lane & 4-lane \\
\hline Mark-Recapture & $\mathrm{Y}$ & $?^{*}$ & $\mathrm{~N}$ & $\mathrm{Y}$ & $\mathrm{Y}$ & $\mathrm{Y}$ & $?$ & $?$ \\
Genetics & $\mathrm{N}^{* *}$ & $\mathrm{~N}^{* *}$ & $\mathrm{~N}$ & $\mathrm{Y}$ & $?$ & $?$ & $\mathrm{Y}$ & $\mathrm{Y}$ \\
\hline
\end{tabular}

Table 6. Summary of highway effects. Movement was reduced across highways, moreso for 4-lane than for 2-lane highways. However, species did not respond to highways as predicted. Vagrant shrews were the species most significantly affected by highways (of both types), followed by chipmunks or voles, and finally, deer mice. ${ }^{*}$ Sample size $=$ one moving vole $* *$ Lower variation (compared to mice and shrews) may have limited our power to detect highway effects, so genetic effects may not be detectable yet, or limited movement may maintain levels of genetic exchange sufficient to prevent significant divergence.

Results from red-backed voles are the most difficult to interpret, and deviated most from our predictions. We captured red-backed voles at just one 4-lane site, St. Regis, where our sample size of moving voles was too small to test for highway effects using mark-recapture. In contrast, mark-recapture data showed that vole movement declined across 2-lane highways, but the genetic data showed no effect; nor were there significant effects on gene flow at 4-lane highways. Three explanations are possible. 1) Populations are large, so drift acts slowly and divergence is slow. Therefore, not enough 
vole generations have passed to allow us to detect population fragmentation using genetic techniques. 2) A small amount of movement - sufficient to maintain similar gene frequencies across highways - is occurring. 3) Additional voles crossed 2-lane highways during fall, winter, or spring and bred there, but were not recaptured in summer 2001. Explanation 3 is less likely to be true, because we would have expected to see this pattern for movement adjacent to the highway as well: we detected eight voles moving adjacent to highways, and only one moving across them. In addition, the mean number of "true" migrants per site across highways was rather low, ranging from zero to three voles. However, our prediction that highway effects would be strongest on a forest-associate was not confirmed; we detected reduced movement, but not reduced gene flow.

We did not detect any decrease in movement for deer mice at 2-lane highways through mark-recapture data or genetic analyses (but genetic data could be analyzed at only one 2-lane site due to low sample sizes at other sites). Both approaches did indicate reduced movement across the 4-lane highway at St. Regis. Effect size varied between sites; although we attempted to control for sources of variation such as rivers and frontage roads, many differences between sites remained. We found much stronger evidence of highway effects at St. Regis than at Tarkio (but the number of "true" migrants across the highway was similar), perhaps because the median strip was so much thinner at Tarkio, making the total crossing distance shorter by almost $40 \mathrm{~m}$. In addition, Tarkio is a much more open site overall than St. Regis, so perhaps mice adapted to this open environment do not perceive the highway as a significant barrier.

Because we detected four individual deer mice crossing I-90 at St. Regis during just 18 nights of trapping, it was surprising to see reduced gene flow. It may be that deer 
mice frequently move relatively large distances to forage or explore, but do not often breed there. Deer mice occurred at higher densities within our study areas than did voles or chipmunks and are thought to be more social than many other rodents, nesting communally to offset cold temperatures (Millar and Derrickson 1992; Foresman 2001 a). On multiple occasions, we captured two and three deer mice per trap, which is possible only if they travel in tight groups. Perhaps a high degree of socialization or low resource demand means that few mice disperse away from their birthplace to breed, at least when a 4-lane highway exists as a deterrent.

In the absence of genetic data for chipmunks (not analyzed due to time constraints) or mark-recapture data for shrews, our interpretation of highway effects on chipmunks and shrews is somewhat challenging. The mark-recapture data strongly suggest that chipmunk movement was reduced across both 2- and 4-lane highways. It is difficult to predict how the genetic data would look for chipmunks, but it is unlikely that we would see genetic differences across 2-lane highways; we detected five individuals that crossed 2-lane highways with limited diurnal trapping. On the other hand, we never detected a chipmunk crossing of a 4-lane highway, so we would expect gene flow to be decreased there.

Evidence of highway effects was stronger for vagrant shrews than for voles or mice. Gene flow was reduced across both 2-and 4-lane highways (at 2/3 sites), and effects were particularly strong at Rainy Lake, a 2-lane site, where only one migrant was identified regardless of the likelihood ratio specified. One 2-lane site, Lolo, did not show the same pattern of reduced gene flow across the highway as did our other highway sites. At Lolo, wet swampy habitat extended right up to the raised road bed on both sides of the 
highway. Because we frequently captured shrews here near the highway edge, we speculate that this may have facilitated movement at Lolo. Since the genetic data showed strong effects of both highway types, it is likely that mark-recapture data would reflect the same pattern. (The logistics of such a study would be considerable because hourly trap checks during the night would be necessary to keep shrews alive).

In addition, the magnitude of the differences between gene flow adjacent to and gene flow across highways was larger for shrews than for voles or mice, particularly the movement index based on misassignment rates. This result was somewhat unexpected since vagrant shrews occur in a variety of habitats, including meadows. We had expected that species occurring in areas with low forest cover would be more likely to successfully cross open pavement. However, we may have underestimated the importance of grass and shrub cover, which may be preferred for foraging and/or provide lower perceived predation risk for shrews. Even when we captured shrews in areas lacking trees, they could potentially remain concealed by grass or brush, which is obviously not possible on an asphalt surface.

The type of vegetation bordering the highway may influence the willingness or ability of small mammals to cross. The vegetation bordering our 4-lane highway (at both sites) was more open and grassy than the vegetation bordering our 2-lane highways. The Montana Department of Transportation mows along the highway edge at St. Regis and Tarkio, and the forest edge is $15-28 \mathrm{~m}$ farther from the highway edge than at 2-lane sites. Among our 2-lane sites, the vegetation is sparsest, and the distance from forest edge to pavement largest, at Lubrecht. However, these vegetation differences did not 
lead to decreased movement across the 2-lane highway at Lubrecht, relative to our other 2-lane sites.

In several cases, our estimates of real migrants seemed to conflict with our results comparing misassignment rates (both real and statistical migrants) adjacent to versus across highways. First, vole gene flow was not reduced across highways (whereas gene flow was reduced for shrews and mice at some sites), yet we detected fewer individuals that were likely to be true migrants than for mice or shrews, particularly for $L R=100$. This counter-intuitive result may be related to lower genetic variation in voles that would cause fewer individuals to be considered real migrants when the stringent cutoff value of $\mathrm{LR}=100$ was imposed. Also, we discussed the possibility that reduced movement (evident in the mark-recapture data from 2-lane highways) may not yet be detectable using genetic techniques. Second, $\mathrm{F}_{\mathrm{ST}}$-values and misassignment rates were similar for deer mice at St. Regis separated by $75 \mathrm{~m}$ and for those separated by $240 \mathrm{~m}$, yet we detected only one real migrant at $240 \mathrm{~m}$, versus 14 migrants at $75 \mathrm{~m}$ with $\mathrm{LR}=10$. There may be a subtle increase in differentiation at the larger distance, such that most misassignments can be shown to be statistical, not actual migrants. Third, the number of "true" mouse migrants was similar for St. Regis and Tarkio, yet $\mathrm{F}_{\mathrm{ST}}$ and misassignment data show decreased gene flow only at St. Regis. This is explained by the fact that increased differentiation (due to decreased gene flow) at St. Regis increases statistical power and thus the odds that the likelihood ratio for potential migrants exceeds a cutoff value of 10 or more. The likelihood ratio misassignment data provide an index to movement, but not a true estimate, because some migrants probably went unsampled. 
Culverts may increase gene flow for both deer mice and vagrant shrews. Gene flow was higher for mice and shrews captured near a culvert at St. Regis (which opened into a high cover area within our trapping grid) than for individuals captured in grids lacking a culvert. This was particularly true for shrews, and may explain why gene flow across the 4-lane highway was higher than gene flow across the 2-lane highway at Rainy Lake. In contrast, culverts did not appear to influence gene flow for red-backed voles or for deer mice at Tarkio (where a nearby culvert did not actually open into our trapping grids, but instead opened into an open grass and gravel area near the highway); mouse gene flow was higher across highways at Tarkio than at St. Regis, but high gene flow did not appear to be attributable to the culvert at Tarkio. While the data suggest that mice and shrews use culverts, this study was not designed specifically to measure the effects of culverts, and all evidence comes from one 4-lane site. However, our results are consistent with the preliminary observations of Foresman (pers. comm.), in a study of culvert use along Highway 93 (4-lane) south of Missoula, Montana. He has photographed approximately 22 deer mice (some were likely photographed more than once) per month per culvert, as well as several shrews and meadow voles (Microtus pennsylvanicus) where there is vegetation near culvert entrances.

Overall levels of genetic differentiation across the study region were low. We were somewhat surprised to see $15-30 \%$ of individuals misassigning among sites 50 $320 \mathrm{~km}(30-200$ miles) apart (but only $1-4 \%$ misassigned when a likelihood ratio of 10 was required). This may be the result of large, widely distributed populations in contiguous forest, where high variation is maintained within subpopulations such that differentiation between them is low. Genetic drift would act slowly in such large 
populations. This conclusion is supported by our finding of extremely high levels of genetic variation at all sites. Even sites where few individuals were captured maintained high allelic diversity, probably because the true extent of populations was much greater than the boundaries of our trapping grids.

Overall low levels of genetic differentiation limited our ability to quantify movement. Since there were low $\mathrm{F}_{\mathrm{ST}^{-}}$-values and erroneous misassignments among sites, we assume that this effect is magnified within sites. For this reason, we do not attempt to turn $\mathrm{F}_{\mathrm{ST}}$-values into estimates of the number of migrants per generation (Wright 1969). This approach would be expected to overestimate the amount of movement across highways. However, we did try to distinguish real migrants from statistical migrants within the assignment test by specifying the odds that a migrant must "beat" before being considered real. In addition, we know that $\mathrm{F}_{\mathrm{ST}}$ is constrained to be low (Charlesworth 1998; Hedrick 1999), because heterozygosity was so high for all three species. However, this high level of genetic variation was a huge advantage when we compared gene flow adjacent to highways to gene flow across highways within sites. Power was high enough that similar values were obtained even when one or two loci were excluded from analysis (Appendix 10 - 11). For example, shrew misassignments across the 4-lane highway at St. Regis increased by only $4 \%$ when we went from five loci to just three loci in the analysis. Also reassuring was the fact that results changed very little when we used different assignment tests (Appendix 10 -11). These results would be much less informative or useful if conclusions depended on which methods were used to estimate gene flow (after screening out inappropriate methods or those that performed poorly). 
To put these results in perspective, we compare them to several other studies. In a study similar to ours, Gerlach and Musolf (2000) studied bank voles (Clethrionomys glareolus) near various roadways in Germany, including a 4-lane highway. C. glareolus are closely related to $C$. gapperi, and this particular German highway had been paved more recently than the 4-lane highway in our study; thus we expected similar or greater levels of genetic divergence in our study. However, at a $50 \mathrm{~m}$ 4-lane highway (much wider than our 4-lane highway, unless the median is included) with a total sample size of 102 voles, they calculated a mean $\mathrm{F}_{\mathrm{ST}}$ of 0.025 . Only our largest $\mathrm{F}_{\mathrm{ST}}$ estimates exceeded this value $(0.03-0.04$ for deer mice and shrews); our estimates for red-backed voles were much smaller, implying more gene flow for voles in our study. The difference may be that the surrounding landscape in Montana is largely unfragmented, and our (narrower) section of highway experiences just 1/5 the traffic volume of the German highway.

Proctor et al. (In Press) estimated $\mathrm{F}_{\mathrm{ST}}$ and misassignment rates for grizzly bears (Ursus arctos), a species with slower generation time but smaller populations than ours, across a 4-lane highway, British Columbia-Alberta Highway 3 (which has similar traffic levels to our 4-lane highway, up to about 7000 vehicles per day). Grizzlies have slower generation times than small mammals, which might cause a delay in detectable genetic divergence, but smaller population sizes, which would accelerate divergence. Their mean $\mathrm{F}_{\text {ST }}$ was 0.034 , with 29 total misassignments out of 219 bears (13\%). Again, our largest $\mathrm{F}_{\mathrm{ST}}$-values were comparable, but our misassignment rates were on average much higher than Proctor et al. (In Press) found, $20-40 \%$ compared to their 13\%. When they used a log-likelihood cutoff value of 3 (bears had to be 1000 times more likely to be from a 
population different from the population of capture), they found only four bears to be true migrants. Using such a high cutoff value for our study seemed inappropriate, since the overall lower levels of differentiation that we observed provide us with less power to distinguish real migrants with such certainty. However, if for comparison we specify LR $=1000$, we would identify no voles, eight mice (two at Lubrecht, four at St. Regis, and two at Tarkio), and one shrew (at Rainy Lake) as real migrants across highways, over two summers of sampling.

Galbusera et al. (2000) estimated gene flow in the endangered Taita thrush (Turdus helleri) in a fragmented landscape, the uplands of southeast Kenya. They sampled birds at sites separated by $5-25 \mathrm{~km}$ of unsuitable arid habitat. Birds are obviously more mobile than small mammals and sites were closer together than ours, so we might expect higher gene flow, but small population size would be expected to have the opposite effect. Their pairwise $\mathrm{F}_{\mathrm{ST}}$ estimates were 0.103 and 0.238 , with no migrants detected from the current generation out of 260 thrushes sampled (but $2-3$ descendants of migrants: Rannala and Mountain (1997)). Our estimates indicated much more gene flow than occurred with endangered thrushes, and in fact, it would have been impossible for us to get $\mathrm{F}_{\mathrm{ST}}$-values so large except perhaps for voles, with such low homozygosities.

We now turn to the question of biological significance: how much of a reduction in population connectivity across highways is considered biologically significant? There are no standards for evaluating the extent to which populations should be connected. The only rule of thumb is the one migrant per generation rule (OMPG), a level of movement which allows local adaptation while minimizing the loss of variation due to drift (Wright 1931; Mills and Allendorf 1996). Although 1 - 10 migrants per generation may be 
sufficient for genetic considerations (Hedrick and Harrison 1995; Mills and Allendorf 1996), higher levels of connectivity may be required for ecological and demographic reasons (Mills et al. In Press). Higher levels of connectivity across highways are desirable, since it is unlikely that local adaptation will occur across this type of barrier. In most cases, conservation biologists and wildlife managers strive to increase population connectivity, mitigating the effects of habitat fragmentation (small, isolated populations with dwindling habitat available and few opportunities for dispersal, matefinding, or recolonization of empty areas). Although natural barriers such as rivers or mountain ranges may fragment populations (and we do not typically try to increase wildlife movement across such barriers), we are often interested in increasing movement across man-made artificial barriers like highways. However, there are several reasons why increased connectivity may not be beneficial. First, disease transfer is facilitated when connectivity is high (Cunningham 1996). Second is the issue of demographic decoupling: extinction risk may be higher when population connectivity is high (Burgman et al. 1993). This takes us back to the "single large versus several small" debate in reserve design; the risk may be higher when all your eggs are in one basket. Third, there are examples in the animal behavior literature of cases when increased movement of certain individuals is not beneficial to other individuals. For territorial species, interactions with non-resident animals may lead to decreased stability or fitness among residents. Although the potential negative effects of connectivity should be considered, it seems likely that the benefits of population connectivity far outweigh the costs in most situations. 
If we consider any decline in observed movement to be significant, then highways present a significant barrier to all species examined in this study, except deer mice at 2lane highways. Even if only a $50 \%$ reduction in observed movement is considered significant, our conclusions remain the same. If however, we require a detectable reduction in gene flow before we consider highways a significant barrier, then only shrews are affected by 2-lane highways, while both deer mice and shrews may be affected by 4-lane highways. If we decide that a $10 \%$ decrease in misassignment rates is required for biological significance, then only shrew connectivity is inhibited by highways of any width. In any event, high abundance, high levels of genetic variation, and the continued presence of these species in the study region suggests that these small mammals can sustain some reduction in population connectivity by highways. However, we cannot predict how ecosystem processes such as seed and mycorrhizal spore dispersal might be affected by decreased connectivity in small mammal populations, or how predators that rely on small mammals as prey might be impacted. To summarize, our results show that highways reduce small mammal population connectivity, but it is difficult to predict how important the effects might be on small mammal survival or reproduction, or on ecosystem processes.

Our goal was to use a suite of species with varying habitat requirements and life histories to illustrate a range of potential effects of highways on small mammals. Although these species are unlikely to face extinction due to highways, other species of special concern (Montana Natural Heritage Program 2001) such as Preble's shrew (Sorex preblei) or the pygmy shrew (Sorex hoyi: on review), that were impossible for us to study may face more significant risks. We recommend that research be done into mitigation 
measures such as underpasses or overpasses, their design and location, and our results suggest that even a generalist species such as a shrew or deer mouse should be considered. Vegetation around crossing structures may be important, as we found increased connectivity only for a culvert that opened into dense cover, and not for a culvert that opened into an open, short grass and gravel area or for a permanently flooded culvert. Obviously, forest species will only cross highways that run through forested areas, so the placement of crossing structures is important. We strongly recommend that reptiles and amphibians be especially targeted, as they may be particularly vulnerable to highway mortality (for example: Wilkins and Schmidly 1980; Bernardino and Dalrymple 1992; Rosen and Lowe 1994; Fahrig et al. 1995; Fowle 1996; Gibbs 1998; Vos and Chardon 1998; Lehtinen et al. 1999; Hels and Buchwald 2001), and may sometimes be forced to cross highways to access overwintering or breeding sites. Highways are ubiquitous across the landscape, and effects on wildlife will only be accentuated as the human population continues to increase and pressures mount for wider roads to accommodate more traffic. 


\section{ACKNOWLEDGEMENTS}

Funding for this project was provided by the Montana Department of Transportation. The National Science Foundation provided an equipment grant for the Li-cor Global IR ${ }^{2}$ System. I am grateful to my committee, L. Scott Mills, Roland Redmond, and Kerry Foresman, as well as to Jeremy Moran, Kristy Pilgrim, Michael Schwartz, Mark Lindberg, and Elizabeth Crone for their input and advice. Douglas Conrey provided technical support and Melissa Hart donated her map-making skills. Ann Riddle, Alicia Awes, and Hope Draheim were instrumental in performing the lab work. Hector Kent, Ben Cummins, Heidi Hagen, Brian Laub, Justin Carnecchia, Erin Clevidence Hill, and Aya Tanigami spent long hours in the field. Thanks also to the Mills lab for providing invaluable feedback: Karen Hodges, Jenny Woolf, Paul Griffin, Sue Cox, Tammy Mildenstein, and John Citta. 


\section{LITERATURE CITED}

Adams, L. 1950. Consumption of ponderosa pine seed by small mammals. Research Note, RS-80, USDA Forest Service, Northern Rocky Mountain Forest and Range Experiment Station, USA.

Allendorf, F.W. and S. R. Phelps. 1981. Use of allele frequencies to describe population structure. Canadian Journal of Fisheries and Aquatic Sciences 38:1507-1514.

Anderson, D. C. and M. L. Folk. 1993. Blarina brevicauda and Peromyscus leucopus reduce overwinter survivorship of acorn weevils in an Indiana hardwood forest. Journal of Mammalogy 74:656-664.

Andrews, A. 1990. Fragmentation of habitat by roads and utility corridors: a review. Australian Zoologist 26:130-141.

Ashley, C. T. and S. T. Warren. 1995. Trinucleotide repeat expansion and human disease. Annual Review of Genetics 29:703-728.

Ashley, M. V. and B. D. Dow. 1994. The use of microsatellite analysis in population biology: background, methods and potential applications. Pages 185-201 in B. Schierwater, B. Streit, G. P. Wagner, and R. DeSalle, editors. Molecular Ecology and Evolution Approaches and Applications. Birkhauser Verlag, Basel, Switzerland.

Balloux, F., E. Ecoffey, L. Fumagalli, J. Goudet, A. Wyttenbach, and J. Hausser. 1998. Microsatellite conservation, polymorphism, and GC content in shrews of the genus Sorex (Insectivora, Mammalia). Molecular Biology and Evolution 15:473-475.

Balloux, F., H. Brunner, N. Lugon-Moulin, J. Hausser, and J. Goudet. 2000. Microsatellites can be misleading: an empirical and simulation study. Evolution 54:1414-1422.

Balloux, F. and N. Lugon-Moulin. 2002. The estimation of population differentiation with microsatellite markers. Molecular Ecology 11:155-165.

Bennett, A. F. 1991. Roads, roadsides and wildlife conservation: a review. Pages 99118 in D. A. Saunders and R. J. Hobbs, editors. Nature Conservation 2: The Role of Corridors. Surrey, Beatty \& Sons, Heidelberg, Victoria, Australia.

Bernardino, F. S., Jr. and G. H. Dalrymple. 1992. Seasonal activity and road mortality of the snakes of the Pa-hay-okee wetlands of Everglades National Park, USA. Biological Conservation 62:71-75.

Bowcock, A. M., A. Ruiz-Linares, J. Tomfohrde, E. Minch, J. R. Kidd, and L. L. CavalliSforza. 1994. High resolution of human evolutionary trees with polymorphic microsatellites. Nature 368:455-457.

Bowne, D. R., J. D. Peles, and G. W. Barrett. 1999. Effects of landscape spatial structure on movement patterns of the hispid cotton rat (Sigmodon hispidus). Landscape Ecology 14:53-65.

Buckner, C. H. 1958. Mammalian predators of the larch sawfly in eastern Manitoba. Proceedings of the 10 $0^{\text {th }}$ International Congress in Entomology 4:353-361.

Burgman, M. A., S. Ferson, and H. R. Akcakaya. 1993. Risk Assessment in Conservation Biology. Chapman and Hall, London, United Kingdom. Pages 186188. 
Buskirk, S. W. and L. F. Ruggiero. 1994. American marten. Pages 7-37 in L. F. Ruggiero, K. B. Aubry, S. W. Buskirk, L. J. Lyon, and W. J. Zielinski, editors. American marten, fisher, lynx, and wolverine in the western United States. General Technical Report RM-254. USDA Forest Service, Rocky Mountain Forest and Range Experiment Station, USA.

Cavalli-Sforza, L. L. and A. W. F. Edwards. 1967. Phylogenetic analysis: models and estimation procedures. American Journal of Human Genetics 19:233-257.

Chakraborty, R. and L. Jin. 1993. A unified approach to study hypervariable polymorphisms: statistical considerations of determining relatedness and population distances. Pages 153-175 in Pena, S. D. J., R. Chakraborty, J. T. Epplen, and A. J. Jeffreys, editors. DNA Fingerprinting: State of the Science. Birkhauser Verlag, Basel, Switzerland.

Charlesworth, B. 1998. Measures of divergence between populations and the effect of forces that reduce variability. Molecular Biology and Evolution 15:538-543.

Chirhart, S. E., R. L. Honeycutt, and I. F. Greenbaum. 2000. Microsatellite markers for the deer mouse Peromyscus maniculatus. Molecular Ecology 9:1661-1686.

Clothier, R. R. 1955. Contributions to the life history of Sorex vagrans in Montana. Journal of Mammalogy 36:214-221.

Cockerham, C. C. 1973. Analysis of gene frequencies. Genetics 74:679-700.

Cornuet, J., S. Piry, G. Luikart, A. Estoup, and M. Solignac. 1999. New methods employing multilocus genotypes to select or exclude populations as origins of individuals. Genetics 153:1989-2000. GeneClass version 1.0.02 (16.II.1999). [http://www.ensam.inra.fr/URLB/geneclass/geneclass.html].

Cunningham, A. A. 1996. Disease risk of wildlife translocations. Conservation Biology 10:349-353.

Di Rienzo, A., A. C. Peterson, J. C. Garza, A. M. Valdes, M. Slatkin, and N. B. Freimer. 1994. Mutational processes of simple-sequence repeat loci in human populations. Proceedings of the National Academy of Sciences, USA 91:3166-3170.

Estoup, A., L. Garnery, M. Solignac, and J. M. Cornuet. 1995. Microsatellite variation in honey bee (Apis mellifera L.) populations: hierarchical genetic structure and test of the infinite allele and stepwise mutation models. Genetics 140:679-695.

Fahrig, L., J. H. Pedlar, S. E. Pope, P. D. Taylor, and J. F. Wegner. 1995. Effect of road traffic on amphibian density. Biological Conservation 73:177-182.

Favre, L., F. Balloux, J. Goudet, and N. Perrin. 1997. Female biased dispersal in the monogamous mammal Crocidura russula: evidence from field data and microsatellite patterns. Proceedings of the Royal Society of London, Series B 264:127-132.

Firestone, K. B., B. A. Houlden, W. B. Sherwin, and E. Geffen. 2000. Variability and differentiation of microsatellites in the genus Dasyurus and conservation implications for the large Australian carnivorous marsupials. Conservation Genetics 1:115-133.

Foresman, K. R. 2001 a. The Wild Mammals of Montana. American Society of Mammalogists, Lawrence, Kansas.

. 2001 . Key to the Mammals of Montana. American Society of Mammalogists, Lawrence, Kansas. 
. 2002. Personal communication. The effects of highways on fragmentation of small mammal populations and modifications of crossing structures to mitigate such impacts. Missoula, Montana, USA.

Fowle, S. 1996. Effects of roadkill mortality on the western painted turtle (Chrysemys picta bellii) in the Mission Valley, western Montana. In G. L. Evink, P. Garrett, D. Zeigler, and J. Berry, editors. Trends in Addressing Transportation Related Wildlife Mortality: Proceedings of the Transportation Related Wildlife Mortality Seminar (now the International Conference on Ecology and Transportation). State of Florida Department of Transportation Environmental Management Office, Tallahassee, Florida, USA.

Frank, J. H. 1967. The effect of pupal predators on a population of winter moth, Operophtera brumata (L.) (Hydriomenidae). Journal of Animal Ecology 36:611-621.

Gaines, M. S. and M. L. Johnson. 1987. Phenotypic and genotypic mechanisms for dispersal in Microtus populations and the role of dispersal in population regulation. Pages 162-179 in B. D. Chepko-Sade and Z. T. Halpin, editors. Mammalian Dispersal Patterns. University of Chicago Press, Chicago, Illinois, USA.

Galbusera, P., L. Lens, T. Schenck, E. Waiyaki, and E. Matthysen. 2000. Genetic variability and gene flow in the globally, critically endangered Taita thrush. Conservation Genetics 1:45-55.

Garza, J. C., M. Slatkin, and N. B. Freimer. 1995. Microsatellite allele frequencies in humans and chimpanzees, with implications for constraints on allele size. Molecular Biology and Evolution 12:594-603.

Gerlach, G. and K. Musolf. 2000. Fragmentation of landscape as a cause for genetic subdivision in bank voles. Conservation Biology 14:1066-1074.

Gibbs, J. P. 1998. Amphibian movements in response to forest edges, roads, and streambeds in southern New England. Journal of Wildlife Management 62:584-589.

Gliwicz, J. 1980. Island populations of rodents: their organization and functioning. Biological Review 55:109-138.

Gockel, J., B. Harr, C. Schlotterer, W. Arnold, G. Gerlach, and D. Tautz. 1997. Isolation and characterization of microsatellite loci from Apodemus flavicollis (rodentia, muridae) and Clethrionomys glareolus (rodentia, cricetidae). Molecular Ecology 6:597-599.

Goertz, J. W. 1964. Influence of habitat quality upon density of cotton rat populations. Ecological Monographs 34:359-381.

Goldstein, D. B., A. Ruiz Linares, L. L. Cavalli-Sforza, and M. W. Feldman. 1995. An evaluation of genetic distances for use with microsatellite loci. Genetics 139:463471.

$1995_{\mathrm{b}}$. Genetic absolute dating based on microsatellites and the origin of modern humans. Proceedings of the National Academy of Sciences USA. 92:6723-6727.

Goldstein, D. B., and D. D. Pollock. 1997. Launching microsatellites: a review of mutation processes and methods of phylogenetic inference. Journal of Heredity 88:335-342.

Goudet, J., M. Raymond, T. DeMeeues, and F. Rousset. 1996. Testing differentiation in diploid populations. Genetics 144:1933-1940. 
Greenwood, P. J. 1980. Mating systems, philopatry, and dispersal in birds and mammals. Animal Behavior 28:1140-1162.

Gunderson, H. L. 1959. Red-backed vole habitat studies in central Minnesota. Journal of Mammalogy 40:405-412.

Gunther, P. M., B. S. Horn, and G. D. Babb. 1983. Small mammal populations and food selection in relation to timber harvest practices in the western Cascade Mountains. Northwest Science 57:32-44.

Guo, S. W. and E. A. Thompson. 1992 a. Performing the exact test of Hardy-Weinberg proportion for multiple alleles. Biometrics 48:361-372.

1992 . A Monte Carlo method for combined segregation and linkage analysis. American Journal of Human Genetics 51:1111-1126.

Haldane, J. B. S. 1954. An exact test for randomness of mating. Journal of Genetics 52:631-635.

Hayes, J. P., S. P. Cross, and P.W. McIntire. 1986. Seasonal variation in mycophagy by the western red-backed vole, Clethrionomys californicus, in southwestern Oregon. Northwest Science 60:250-257.

Hayward, G. D., P. H. Hayward, and E. O. Garton. 1993. Ecology of boreal owls in the northern Rocky Mountains. Wildlife Monographs 124:1-59.

Hedrick, A. 1995. Gene flow and genetic restoration: the Florida panther as a case study. Conservation Biology 9:996-1007.

. 1999. Perspective: highly variable loci and their interpretation in evolution and conservation. Evolution 53:313-318.

Hels, T. and E. Buchwald. 2001. The effect of road kills on amphibian populations. Biological Conservation 99:331-340.

Hoffmann, R. S. and D. L. Pattie. 1968. A Guide to Montana Mammals: Identification, Habitat, Distribution, and Abundance. University of Montana Printing Service, Missoula, Montana, USA.

Ishibashi, Y., T. Saitoh, S. Abe, and M. C. Yoshida. 1995. Polymorphic microsatellite DNA markers in the gray red-backed vole Clethrionomys rufocanus bedfordiae. Molecular Ecology 4:127-128.

Jarne, P. and P. J. L. Lagoda. 1996. Microsatellites, from molecules to populations and back. Trends in Ecology and Evolution 11:424-429.

Johnson, C. N. 1996. Interactions between mammals and ectomycorrhizal fungi. Trends in Ecology and Evolution 11:503-507.

Kimura, M. and J. F. Crow. 1964. The number of alleles that can be maintained in a finite population. Genetics 49:725-738.

Kozakiewicz, M. 1976. Migratory tendencies in population of bank voles and description of migrants. Acta Theriologica 21:321-338.

Krebs, C. J., B. C. Keller, and R. H. Tamarin. 1969. Microtus population biology: demographic changes in fluctuating populations of $M$. ochrogaster and $M$. pennsylvanicus in southern Indiana. Ecology 50:587-607.

Krebs, C. J. and J. H. Myers. 1974. Population cycles in small mammals. Advances in Ecological Research 8:267-399. 
Lair, K. P. 2001. The effects of forest fragmentation and forest edge on southern redbacked vole abundance and survival. M.S. Thesis, University of Montana, Missoula, Montana, USA.

Lambin, X. 1994. Natal philopatry, competition for resources, and inbreeding avoidance in Townsend's voles (Microtus townsendii). Ecology 75:224-235.

Lehtinen, R. M., S. M. Galatowitsch, and J. R. Tester. 1999. Consequences of habitat loss and fragmentation for wetland amphibian assemblages. Wetlands 19:1-12.

Levinson, G. and G. A. Gutman. 1987. High frequency of short frameshifts in polyCA/GT tandem repeats borne by bacteriophage M13 in Escherichia coli K-12. Nucleic Acids Research 15:5323-5338.

Li, C. Y., C. Maser, Z. Maser, and B. A. Caldwell. 1986. Role of three rodents in forest nitrogen fixation in western Oregon: another aspect of mammal-mycorrhizal fungustree mutualism. Great Basin Naturalist 46:411-414.

LI-COR, Inc. 2002. DNA sequencing, genetic analysis, and protein imaging systems. [http://bio.licor.com/SAGA/BioSoft1.html].

Lidicker, W. Z., Jr. 1975. The role of dispersal in the demography of small mammals. Pages 103-128 in F. B. Golley, K. Petrusewicz, and L. Ryszkowski, editors. Small Mammals: their Production and Population Dynamics. Cambridge University Press, London, England.

Mader, H. J. 1984. Animal habitat isolation by roads and agricultural fields. Biological Conservation 29:81-96.

Maldonado, J. Unpublished data. Microsatellite primer sequences developed for the ornate shrew, Sorex ornatus. Smithsonian Institute, Washington D.C., USA.

Marks, G. C. and T. T. Kozlowski. 1973. Ectomycorrhizae: their ecology and physiology. Academic Press, New York, USA.

Maser, C., J. M. Trappe, and R. A. Nussbaum. 1978. Fungal small mammal interrelationships with emphasis on Oregon coniferous forests. Ecology 59:799-809.

Maser, Z., C. Maser, and J. M. Trappe. 1985. Food habits of the northern flying squirrel (Glaucomys sabrinus) in Oregon. Canadian Journal of Zoology 63:1084-1088.

McCracken, K. E. 1990. Microhabitat and dietary partitioning in three species of shrews at Yellow Bay, Montana. Master's Thesis, University of Montana, Missoula, Montana, USA.

Mech, S. G. and J. G. Hallett. 2001. Evaluating the effectiveness of corridors: a genetic approach. Conservation Biology 15:467-474.

Millar, J. S., and E. M. Derrickson. 1992. Group nesting in Peromyscus maniculatus. Journal of Mammalogy 73:403-407.

Mills, L. S. and F. W. Allendorf. 1996. The one-migrant-per-generation rule in conservation and management. Conservation Biology 10:1509-1518.

Mills, L. S. and D. A. Tallmon. 1999. The role of genetics in understanding forest fragmentation. Pages 171-186 in Forest Fragmentation: Wildlife and Management Implications. J. A. Rochelle, L. A. Lehmann, and J. Wisniewski, editors. Koninklijke Brill NV, Leiden, The Netherlands. 
Mills, L. S., M. K. Schwartz, D. A. Tallmon, and K. P. Lair. In Press. Measuring and interpreting changes in connectivity for mammals in coniferous forests. In $\mathrm{C}$. Zabel and B. Anthony, editors. Mammal Community Dynamics: Management and Conservation in the Coniferous Forests of Western North America. Cambridge University Press, Cambridge, England.

Montana Natural Heritage Program. 2001. Animal species of concern. [http://nhp.nris.state.mt.us].

Moran, J. 2001. Changes in small mammal abundance near highways: fence effect or edge effects? Undergraduate senior thesis, University of Montana, Missoula, Montana, USA.

Nagylaki, T. 1998. Fixation indices in subdivided populations. Genetics 148:13251332.

Nauta, M. J. and F. J. Weissing. 1996. Constraints on allele size at microsatellite loci: implications for genetic differentiation. Genetics 143:1021-1032.

Nei, M. 1972. Genetic distance between populations. American Naturalist 106:283-292. . 1973. Analysis of gene diversity in subdivided populations. Proceedings of the National Academy of Sciences USA 70:3321-3323.

. 1987. Molecular evolutionary genetics. Columbia University Press, New York, New York, USA.

Norrdahl, K. and E. Korpimaki. 1998. Does mobility or sex of voles affect risk of predation by mammalian predators? Ecology 79:226-232.

Ohta, T. and M. Kimura. 1973. The model of mutation appropriate to estimate the number of electrophoretically detectable alleles in a genetic population. Genetic Research 22:201-204.

Oxley, D. J., M. B. Fenton, and G. R. Carmody. 1974. The effects of roads on populations of small mammals. Journal of Applied Ecology 11:51-59.

Paetkau, D., W. Calvert, I. Stirling, and C. Strobeck. 1995. Microsatellite analysis of population structure in Canadian polar bears. Molecular Ecology 3:489-495.

Paetkau, D., L. P. Waits, P. L. Clarkson, L. Craighead, and C. Strobeck. 1997. An empirical evaluation of genetic distance statistics using microsatellite data from bear (Ursidae) populations. Genetics 147:1943-1957.

Pattie, D. L. and N. A. M. Verbeek. 1967. Alpine mammals of the Beartooth Mountains. Northwest Science 41:110-117.

Pavone, L. V. and R. Boonstra. 1985. The effects of toe clipping on the survival of the meadow vole (Microtus pennsylvanicus). Canadian Journal of Zoology 63:499-501.

Pearson, D. E. 1994. Habitat use by the southern red-backed vole (Clethrionomys gapperi): response of an old-growth associated species to succession. Master's Thesis, University of Montana, Missoula, Montana, USA.

1999. Small mammals of the Bitterroot National Forest: a literature review and annotated bibliography. General Technical Report RMRS-GTR-25, USDA Forest Service, Rocky Mountain Research Station, Ogden, Utah, USA.

Petri, B., S. Paabo, A. Von Haeseler, and D. Tautz. 1997. Paternity assessment and population subdivision in a natural population of the larger mouse-eared bat Myotis myotis. Molecular Ecology 6:235-242. 
Platt, W. J. and N. R. Blakley. 1973. Short-term effects of shrew predation upon invertebrate prey. Proceedings of the Iowa Academy of Science 80:60-66.

Pritchard, J. K., M. Stephens, and P. Donnelly. 2000. Inference of population structure using multilocus genotype data. Genetics 155:945-959.

Proctor, M. F., B. N. McClellan, and C. Strobeck. In Press. Population fragmentation of grizzly bears in southeastern British Columbia, Canada. Ursus.

Rannala, B. and J. L. Mountain. 1997. Detecting immigration by using multilocus genotypes. Proceedings of the National Academy of Sciences USA 94:9197-9201.

Raymond, M. and F. Rousset. 1995. GENEPOP (version 1.2): population genetics software for exact tests and ecumenicism. Journal of Heredity 86: 248-249. GENEPOP Internet Version 3.1c. [http://wbiomed.curtin.edu.au/genepop].

Rice, W. R. 1989. Analyzing tables of statistical tests. Evolution 43:223-225.

Rosen, P. C. and C. H. Lowe. 1994. Highway mortality of snakes in the Sonoran Desert of southern Arizona. Biological Conservation 68:143-148.

Sanders, F. B., B. Mosse, and P. B. Tinker. 1975. Endomycorrhizae. Academic Press, London, England.

Schlotterer, C. and J. Pemberton. 1994. The use of microsatellites for genetic analysis of natural populations. Pages 203-214 in B. Schierwater, B. Streit, G. P. Wagner, and R. DeSalle, editors. Molecular Ecology and Evolution Approaches and Applications. Birkhauser Verlag, Basel, Switzerland.

Schmidt, W. C. and R. C. Shearer. 1971. Larix occidentalis nutt, western larch. Pages 160-172 in R. M. Burns and B. H. Honkala, technical coordinators. Silvics of North America. Agricultural Handbook 654. USDA Forest Service, Washington D. C., USA.

Seber, G. A. F. 1982. The estimation of animal abundance and related parameters. 2nd edition. Macmillan, New York, USA.

Sekgororoane, G. B. and T. G. Dilworth. 1995. Relative abundance, richness, and diversity of small mammals at induced forest edges. Canadian Journal of Zoology 73:1432-1437.

Sheppe, W. 1965. Island populations and gene flow in the deer mouse, Peromyscus leucopus. Evolution 19:480-495.

Shriver, M. D., L. Jin, R. Chakraborty, and E. Boerwinkle. 1993. VNTR allele frequency distributions under the stepwise mutation model: a computer simulation approach. Genetics 134:983-993.

Shriver, M. D., L. Jin, R. E. Ferrel, and R. Deka. 1997. Microsatellite data support an early population expansion in Africa. Genome Research 7:586-591.

Slatkin, M. 1985. Rare alleles as indicators of gene flow. Evolution 39:53-65. . 1995. A measure of population subdivision based on microsatellite allele frequencies. Genetics 139:457-462.

Spellerberg, I. F. 1998. Ecological effects of roads and traffic: a literature review. Global Ecology and Biogeography Letters 7:317-333.

Spencer, A. W. and D. Pettus. 1966. Habitat preferences of five sympatric species of long-tailed shrews. Ecology 4:676-683. 
Steinberg, E. K. and C. E. Jordan. 1997. Using molecular genetics to learn about the ecology of threatened species: the allure and the illusion of measuring genetic structure in natural populations. Pages 440-460 in P. Fiedler and P. Kareiva, editors. Conservation Biology for the Coming Decade. Chapman and Hall, New York, New York, USA.

Sullivan, T. P. 1979. Demography of populations of deer mice in coastal forest and clear-cut (logged) habitats. Canadian Journal of Zoology 57:1636-1648.

Swihart, R. K. and N. A. Slade. 1984. Road crossing in Sigmodon hispidus and Microtus ochrogaster. Journal of Mammalogy 65:357-360.

Takezaki, N. and M. Nei. 1996. Genetic distances and reconstruction of phylogenetic trees from microsatellite DNA. Genetics 144:389-399.

Tallmon, D. A., H. M. Draheim, L. S. Mills, and F. W. Allendorf. 2002. Insights into recently fragmented vole populations from combined genetic and demographic data. Molecular Ecology 11:699-709.

Tallmon, D. A., L. S. Mills, N. J. Radke, E. S. Jules. In Prep. The rise of mice and the fall of trillium in a fragmented landscape.

Tevis, L. Jr. 1953. Stomach contents of chipmunks and mantled squirrels in northeastern California. Journal of Mammalogy 34:316-324.

Trombulak, S. C. and C. A. Frissell. 2000. Review of ecological effects of roads on terrestrial and aquatic communities. Conservation Biology 14:18-30.

United States Department of Agriculture Forest Service. 1985. Final environmental impact statement for the Medicine Bow National Forest and Thunder Basin National Grassland land and resource management plan. USDA Forest Service, Laramie, Wyoming, USA.

Ure, D. C. and C. Maser. 1982. Mycophagy of red-backed voles in Oregon and Washington. Canadian Journal of Zoology 60:3307-3315.

Valdes, A. M., M. Slatkin, and N. B. Freimer. 1993. Allele frequencies at microsatellite loci: the stepwise mutation model revisited. Genetics 133:737-749.

Vander Wall, S. B. 1993. Cache site selection by chipmunks (Tamias spp.) and its influence on the effectiveness of seed dispersal in Jeffrey pine (Pinus jeffreyi). Oecologia 96:246-252.

Varvio, S., R. Chakraborty, and M. Nei. 1986. Genetic variation in subdivided populations and conservation genetics. Heredity 57:189-198.

Vos, C. C. and J. P. Chardon. 1998. Effects of habitat fragmentation and road density on the distribution pattern of the moor frog Rana arvalis. Journal of Applied Ecology 35:44-56.

Waser, P. M. and C. Strobeck. 1998. Genetic signatures of interpopulation dispersal. Trends in Ecology and Evolution 13:43-44.

Weber, J. L. and C. Wong. 1993. Mutation of human short tandem repeats. Human Molecular Genetics 2:1123-1128.

Weckwerth, R. P. and V. D. Hawley. 1962. Marten food, habitats, and population fluctuations in Montana. Journal of Wildlife Management 26:55-74.

Weir, B. S. and C. C. Cockerham. 1984. Estimating F-statistics for the analysis of population structure. Evolution 38:1358-1370. 
Weir, B. S., J. Reynolds, and K. G. Dodds. 1990. The variance of sample heterozygosity. Theoretical Population Biology 37:235-253.

Werner, W. E. 1956. Mammals of the thousand island region, New York. Journal of Mammalogy 37:395-406.

Whitlock, M. C. and D. E. McCauley. 1999. Indirect measures of gene flow and migration: $\mathrm{F}_{\mathrm{ST}} \neq 1 /(4 \mathrm{Nm}+1)$. Heredity $82: 117-125$.

Wilkins, K. T. and D. J. Schmidly. 1980. Highway mortality of vertebrates in southeastern Texas. Texas Journal of Science 32:343-350.

Wolff, J. O. 1993. What is the role of adults in mammalian juvenile dispersal? Oikos 68:173-176.

Wood, M. D. and N. A. Slade. 1990. Comparison of ear-tagging and toe-clipping in prairie voles, Microtus ochrogaster. Journal of Mammalogy 71:252-255.

Wright, S. 1931. Evolution in Mendelian populations. Genetics 16:97-259.

. 1951. The genetical structure of populations. Annals of Eugenics 15:323-354. . 1969. Evolution and the genetics of populations. Volume 2. The Theory of Gene Frequencies. University of Chicago Press, Chicago, Illinois, USA.

Wyttenbach, A., L. Favre, and J. Hausser. 1997. Isolation and characterization of simple sequence repeats in the genome of the common shrew. Molecular Ecology 6:797800 . 


\section{APPENDIX 1 - SMALL MAMMAL ABUNDANCE \& VEGETATION SURVEYS}

This work resulted from a collaboration with Jeremy Moran, reported in his undergraduate senior thesis (Moran 2001), funded by the National Science Foundation EPSCoR (Experimental Program to Stimulate Competitive Research), and an Irene Evers Scholarship from the University of Montana School of Forestry. J. Moran's goal was to determine whether abundance patterns were correlated with differences in vegetation between edge and interior, or whether the presence of the highway itself seemed to be the determining factor.

Vegetation Surveys: We collected vegetation data within circular plots of $10 \mathrm{~m}$ radius and along $20 \mathrm{~m}$ transects passing through the plot center, oriented parallel to the highway. For logistical reasons, we centered vegetation plots on trap locations, using stratified random sampling to choose among trap locations. Using each row (rows are parallel to the highway) as a stratum, and randomly choosing one trap location from each stratum, we sampled seven plots per trapping grid (Figure 2). Stratifying in this way made sense because we expected vegetation structure to change from forest edge (highway) to interior. Specifically, we measured:

1) Dominant species ( 2 or 3 ) in three categories: $>2 \mathrm{~m}$ (trees), $0.5-2 \mathrm{~m}$ (shrubs and seedlings), and $<0.5 \mathrm{~m}$ (ground layer).

2) Percent of ground covered by tree canopy in size categories: very large $>76.2 \mathrm{~cm}$ (30 inches) dbh; large 53.3-76.2 cm (21-30 inches) dbh; medium 22.9-53.2 cm (9-20.9 inches) dbh; pole 12.7-22.8 $\mathrm{cm}$ (5-8.9 inches) dbh; sapling >1.5 $\mathrm{m}$ (59 inches) tall, < $12.7 \mathrm{~cm}$ (5 inches) dbh; seedling $<1.5 \mathrm{~m}$ (59 inches) tall.

3) Percent cover of trees, shrubs, forbs, grass, ferns, dead wood, moss, and bare ground. 
4) Horizontal understory cover, defined as the percent of a $1 \mathrm{~m}$ square piece of fabric that was covered by vegetation when held vertically, touching the ground. An observer, 1 $\mathrm{m}$ from the canvas, differentiated between the bottom and top $0.5 \mathrm{~m}$. Horizontal cover was measured in four directions at $2.5,7.5,12.5$, and $17.5 \mathrm{~m}$ along the transect.

5) Ground cover by lifeform (tree, shrub, forb, grass - live, grass - dead, fern, moss, rock, dead wood, and bare ground), plus the coverage and depth of the litter duff layer and number of conifer cones in $1 \mathrm{~m}$ square plots placed at $5 \mathrm{~m}$ and at $15 \mathrm{~m}$ along the $20 \mathrm{~m}$ transect.

6) Canopy cover measured every $2 \mathrm{~m}$ along the $20 \mathrm{~m}$ transect.

7) Length and diameter of all coarse woody debris ( $>1 \mathrm{~cm}$ in diameter) crossing the $20 \mathrm{~m}$ transect.

8) Species composition for those species occupying $>5 \%$ of the plot.

9) Slope and aspect, averaged over the plot.

Average per grid abundance estimates are presented in the main text, Figure 5. Means and standard deviations for canopy cover, horizontal understory cover, ground cover, and dead wood are shown in table 1.1. Means are reported for each site and for trapping grids within sites (Table1.2). 
Vegetation patterns across sites

\begin{tabular}{|l|rr|rr|rr|rr|rr|}
\hline Cover (\%) & \multicolumn{2}{|c|}{ Lolo } & \multicolumn{2}{|c|}{ Lubrecht } & \multicolumn{2}{c|}{ Rainy Lake } & \multicolumn{2}{c|}{ St. Regis } & \multicolumn{2}{c|}{ Tarkio } \\
\cline { 2 - 11 } & Mean & SD & Mean & SD & Mean & SD & Mean & SD & Mean & SD \\
\hline Canopy & 14.5 & 7.5 & 14.1 & 11.6 & 16.0 & 6.6 & 13.3 & 8.5 & 10.6 & 6.3 \\
Horizontal & 12.2 & 19.3 & 13.3 & 16.2 & 16.3 & 20.1 & 19.1 & 20.8 & 10.4 & 10.8 \\
Ground & 99.3 & 2.3 & 99.0 & 4.5 & 98.3 & 6.0 & 98.6 & 4.9 & 95.4 & 12.8 \\
Dead Wood & 7.2 & 12.6 & 15.2 & 17.5 & 20.8 & 23.0 & 19.4 & 20.5 & 6.5 & 10.7 \\
\hline
\end{tabular}

1.1. Vegetation patterns differed little among sites, except that cover tended to be slightly lower at Tarkio

dead wood cover was also low at Lolo). Variation was high and was partly attributable to changes from the

highway edge to the forest interior, particularly at St. Regis where the first $1-2$ rows of traps were in an open, mowed grassy area. Only the highway trapping grids (not the forest interior grids) were averaged here. Canopy cover is the area covered by tree canopy. Horizontal cover refers to the percent of a $1 \mathrm{~m}$ wide piece of fabric that was covered by vegetation when held vertically, from the soil surface to $0.5 \mathrm{~m}$ above the ground. Ground cover could be any type of vegetation or rock (non-bare ground). Dead wood cover was a part of the ground cover measurement, recorded in two $1 \mathrm{~m}$ square areas per vegetation plot. More detailed information on coarse woody debris is available: length and width of all debris ( $>1 \mathrm{~cm}$ in diameter) encountered along $20 \mathrm{~m}$ transects. Sample size was 280 for canopy cover, 112 for horizontal cover, and 56 for ground and dead wood cover. At each point where measurements were taken, we recorded horizontal cover for all four cardinal directions; these four measurements were highly correlated and non-independent, so the four subsamples were averaged at each of 112 locations for a sample size of 112 . 
Vegetation patterns at Lolo (2-lane)

\begin{tabular}{|l|rr|rr|rr|rr|}
\hline Cover (\%) & \multicolumn{2}{|c|}{ NE } & \multicolumn{2}{|c|}{ NW } & \multicolumn{2}{|c|}{ SE } & \multicolumn{2}{c|}{ SW } \\
\cline { 2 - 8 } & Mean & SD & Mean & SD & Mean & SD & Mean & SD \\
\hline Canopy & 16.5 & 4.3 & 20.2 & 2.8 & 9.1 & 7.9 & 11.9 & 8.3 \\
Horizontal & 7.9 & 11.3 & 10.3 & 13.1 & 10.2 & 16.5 & 20.6 & 29.6 \\
Ground & 98.4 & 4.1 & 99.8 & 0.8 & 99.9 & 0.3 & 99.3 & 1.5 \\
Dead Wood & 6.4 & 5.6 & 11.1 & 19.0 & 1.9 & 2.2 & 9.4 & 15.1 \\
\hline
\end{tabular}

Vegetation patterns at Lubrecht (2-lane)

\begin{tabular}{|l|rr|rr|rr|rr|rr|rr|}
\hline Cover (\%) & \multicolumn{2}{|c|}{ NE } & \multicolumn{2}{|c|}{ NW } & \multicolumn{2}{|c|}{ SE } & \multicolumn{2}{|c|}{ SW } & \multicolumn{2}{|c|}{ NE1 } & \multicolumn{2}{c|}{ NW1 } \\
\cline { 2 - 12 } & Mean & SD & Mean & SD & Mean & SD & Mean & SD & Mean & SD & Mean & SD \\
\hline Canopy & 13.2 & 4.9 & 9.4 & 6.6 & 20.8 & 19.5 & 12.9 & 4.9 & 12.5 & 6.1 & 15.0 & 5.2 \\
Horizontal & 7.3 & 8.8 & 7.5 & 8.1 & 18.8 & 18.2 & 19.6 & 21.4 & 11.1 & 15.1 & 8.1 & 11.5 \\
Ground & 99.8 & 0.8 & 96.4 & 8.6 & 100 & 0 & 99.9 & 0.5 & 95.6 & 7.0 & 99.2 & 2.7 \\
Dead Wood & 18.9 & 24.3 & 12.6 & 14.4 & 14.4 & 14.3 & 14.8 & 16.5 & 6.6 & 7.8 & 4.6 & 2.6 \\
\hline
\end{tabular}

Vegetation patterns at Rainy Lake (2-lane)
\begin{tabular}{|l|rrr|rr|rr|rr|rr|r|}
\hline Cover (\%) & \multicolumn{2}{|c|}{ NE } & \multicolumn{2}{|c|}{ NW } & \multicolumn{2}{|c|}{ SE } & \multicolumn{2}{|c|}{ SW } & NE1 & \multicolumn{2}{|c|}{ SE1 } \\
\cline { 2 - 13 } & Mean & SD & Mean & SD & Mean & SD & Mean & SD & Mean & SD & Mean & SD \\
\hline Canopy & 14.0 & 7.1 & 18.5 & 5.9 & 13.2 & 6.9 & 18.2 & 4.4 & 9.7 & 6.1 & 9.5 & 6.7 \\
Horizontal & 20.4 & 26.0 & 20.1 & 22.9 & 13.9 & 15.2 & 10.9 & 12.7 & 9.4 & 9.4 & 7.7 & 7.4 \\
Ground & 98.4 & 4.0 & 100 & 0 & 94.6 & 10.8 & 99.9 & 0.3 & 89.9 & 18.8 & 99.1 & 1.8 \\
Dead Wood & 16.6 & 24.4 & 18.8 & 24.5 & 21.0 & 21.5 & 26.9 & 22.8 & 8.1 & 9.5 & 6.5 & 7.9 \\
\hline
\end{tabular}


Vegetation patterns at St. Regis (4-lane)

\begin{tabular}{|l|rr|rr|rr|rr|rr|rr|}
\hline Cover (\%) & \multicolumn{2}{|c|}{ NE } & \multicolumn{2}{|c|}{ NW } & \multicolumn{2}{|c|}{ SE } & \multicolumn{2}{c|}{ SW } & \multicolumn{2}{c|}{ NE1 } & \multicolumn{2}{c|}{ NW } \\
\cline { 2 - 12 } & Mean & SD & Mean & SD & Mean & SD & Mean & SD & Mean & SD & Mean & SD \\
\hline Canopy & 12.1 & 7.9 & 13.8 & 8.5 & 13.3 & 9.1 & 14.0 & 8.5 & 14.0 & 5.3 & 8.6 & 5.9 \\
Horizontal & 12.2 & 14.5 & 33.2 & 29.0 & 14.3 & 15.1 & 16.8 & 14.7 & 14.4 & 15.0 & 11.2 & 15.2 \\
Ground & 97.1 & 9.3 & 98.1 & 2.9 & 99.6 & 0.9 & 99.7 & 0.6 & 97.0 & 10.7 & 95.3 & 6.9 \\
Dead Wood & 15.4 & 15.2 & 23.6 & 20.3 & 18.4 & 26.0 & 20.3 & 20.4 & 41.1 & 27.4 & 22.8 & 22.0 \\
\hline
\end{tabular}

\section{Vegetation patterns at Tarkio (4-lane)}

\begin{tabular}{|l|rr|rr|rr|rr|}
\hline Cover (\%) & \multicolumn{2}{|c|}{ NE } & \multicolumn{2}{|c|}{ NW } & \multicolumn{2}{|c|}{ SE } & \multicolumn{2}{c|}{ SW } \\
\cline { 2 - 8 } & Mean & SD & Mean & SD & Mean & SD & Mean & SD \\
\hline Canopy & 11.6 & 8.0 & 11.6 & 5.0 & 10.3 & 5.2 & 8.8 & 6.4 \\
Horizontal & 16.4 & 13.6 & 10.0 & 11.8 & 9.9 & 8.3 & 5.2 & 4.6 \\
Ground & 96.4 & 8.2 & 98.9 & 2.9 & 92.8 & 18.1 & 93.6 & 16.3 \\
Dead Wood & 4.4 & 8.2 & 6.1 & 9.0 & 2.2 & 2.9 & 13.4 & 16.0 \\
\hline
\end{tabular}

Table 1.2. Vegetation patterns differed little within sites. A meadow covered about half of the SE grid at Lolo, which is apparent from the low canopy and dead wood cover. Cover was low in the forest interior grids at Rainy Lake because this area had been logged, and only small trees remained. Canopy cover was somewhat low in the NW1 interior grid at St. Regis because this area had been logged. Variation was high and was partly attributable to changes from the highway edge to the forest interior. Trapping grids were denoted according to their position around the highway; those ending in "1" were forest interior trapping grids. Canopy cover is the area covered by tree canopy. Horizontal cover refers to the percent of a $1 \mathrm{~m}$ wide piece of fabric that was covered by vegetation when held vertically, from the soil surface to $0.5 \mathrm{~m}$ above the ground. Ground cover could be any type of vegetation or rock (non-bare ground). Dead wood cover was a part of the ground cover measurement, recorded in two $1 \mathrm{~m}$ square areas per vegetation plot. More detailed information on coarse woody debris is available: length and width of all debris ( $>1 \mathrm{~cm}$ in diameter) encountered along $20 \mathrm{~m}$ transects. Sample size per trapping grid was 70 for canopy cover, 28 for horizontal cover, and 14 for ground and dead wood cover. At each point where measurements were taken, we recorded horizontal cover for all four cardinal directions; these four measurements were highly correlated and non-independent, so the four subsamples were averaged at each of 28 locations for a sample size of 28 . 


\section{APPENDIX 2 - MARKING ANIMALS}

Toe clipping has not been shown to affect survival (Pavone and Boonstra 1985), body mass, residence time in trapping grids, or long-term recapture rates relative to other marking techniques (Wood and Slade 1990). We clipped two toes per animal and never more than one per foot. Toes healed quickly after clipping, and we never observed any infection. Furthermore, toe clipping provides a high quality genetic sample (Tallmon et al. 2002). Thus, we felt that toe clipping was a humane and practical technique, unlikely to bias estimation of movement rates or abundance.

Ear tagging was somewhat more problematic, because sometimes ears became infected or torn. This did not occur often enough for us to stop ear tagging, but it resulted in tag loss for four chipmunks at St. Regis in 2000, and several more in 2001. Additional tags were lost between the end of the 2000 field season and the beginning of the 2001

field season. In some cases within a field season, we could determine the identity of animals that had lost tags based on which ear was torn, sex, weight, location, and whether the animal with that number continued to be captured with ear tag intact. Tag loss is not an issue when toe clipping is used to permanently mark individuals. 


\section{APPENDIX 3 - MICROSATELLITES}

Since small mammals have short generation times ( $1-4$ generations per year), it is possible that genetic divergence between populations separated by highways has occurred, even though highways are relatively recent features of the landscape. Low levels of gene flow between populations will prevent complete fixation of certain alleles, but more substantial flow is necessary to prevent genetic differentiation due to genetic drift (Allendorf and Phelps 1981; Mills and Allendorf 1996). We have chosen to use microsatellites to study gene flow and subdivision, because their high mutation rates and high variation give relatively high power to detect genetic subdivision between recently fragmented populations.

Microsatellites are highly variable non-coding regions of nuclear DNA consisting of a series of repeats of two to six base pairs. They are codominant and are inherited in a mendelian fashion (Ashley and Dow 1994). Microsatellites are typically highly polymorphic, with average expected heterozygosity well above $50 \%$ in most cases (Bowcock et al. 1994; Jarne and Lagoda 1996). Microsatellite loci mutate rapidly; the average mutation rate is $10^{-3}$ per generation, two to three orders of magnitude higher than values known for allozymes (Weber and Wong 1993; Jarne and Lagoda 1996). There has been much discussion about the appropriate mutation model for microsatellites (Appendix 4), with implications for the way that genetic distance is calculated. Although microsatellites are thought to be neutral in most cases, there may be an upper limit to the number of repeats, and some microsatellites have been associated with disease (Goldstein and Pollock 1997). Microsatellites are easily scorable by measuring the number of base pairs relative to a ladder of known size. 


\section{APPENDIX 4 - MUTATION MODELS}

Analysis of population structure depends on correctly identifying the mutation rate and model, although Cornuet et al. (1999) show that methods such as the assignment test are somewhat robust to choice of mutation model (but higher power is achieved when the assumed mutation model is correct and is the infinite alleles model). There has been much discussion of the appropriate mutation model for microsatellites (Shriver et al. 1993; Valdes et al. 1993; Jarne and Lagoda 1996; Goldstein and Pollock 1997). The two most commonly discussed models are the infinite alleles model (IAM: Kimura and Crow 1964) and the stepwise mutation model (SMM: Ohta and Kimura 1973). The IAM states that there are an infinite number of possible alleles, with no restriction on allele size. Each mutation creates a new allele at rate $\mu$, and all possible alleles are equally likely to occur upon mutation. The SMM states that each mutation adds or subtracts (with equal probability $\mu$ ) a single unit to or from the current allele. A likely mechanism is DNA slippage, whereby the repeat units on the two DNA strands may anneal out of register, resulting in expansion or contraction of the microsatellite following replication or repair (Levinson and Gutman 1987; Ashley and Dow 1994; Schlotterer and Pemberton 1994).

Modifications to the SMM allow occasional additions and subtractions of more than one unit at a time (Di Rienzo et al. 1994), suggest a bias toward adding or subtracting units (Ashley and Warren 1995), and indicate a possible upper limit on allele size (Garza et al. 1995). The favored mutation model is the SMM (Valdes et al. 1993), recognizing that this is a simplification of reality, but no consensus has emerged. Shriver et al. (1993) found that computer simulations suggested that the true mutation model for microsatellites was intermediate to the IAM and SMM, because the SMM predictions 
matched the patterns for microsatellites, except that the SMM underestimated the number of alleles per locus. Some differentiation measures were developed under the IAM, and some under the SMM. For example, Wright's $F_{\text {ST }}$ (Wright 1931) and Nei's $G_{\text {ST }}$ (Nei 1973) are based on the IAM, while Slatkin's $\mathrm{R}_{\mathrm{ST}}$ (Slatkin 1995), Goldstein's ASD and $(\delta \mu)^{2}$ (Goldstein et al. 1995 a, b) are based on the SMM.

Nauta and Weissing (1996) theorized that because mutation will eventually return allele frequencies to previous conditions by chance, constraining the amount of divergence that can occur, microsatellites should only be used when the time scale of interest is short (i.e., not for phylogenetic inference). This recommendation does not conflict with our usage of microsatellite data. 


\section{APPENDIX 5 - HARDY-WEINBERG AND LINKAGE DISEQUILIBRIUM}

Before proceeding with analyses of gene flow, we had to first test for violations of two required assumptions: Hardy-Weinberg (H-W) equilibrium and linkage equilibrium. $\mathrm{H}-\mathrm{W}$ equilibrium refers to the fact that in a randomly mating population, genotypic frequencies will be equal to the product of the frequencies of the two alleles making up the genotype. A homozygote has two copies of the same allele, so the expected genotype frequency of the homozygote in the population is the square of the frequency of that allele. A heterozygote has one copy of two different alleles, so the expected genotype frequency of the heterozygote in the population is twice the product of the frequency of these two alleles. Most tests of genetic differentiation and gene flow assume that populations are in $\mathrm{H}-\mathrm{W}$ equilibrium, and they use these expected proportions in calculations.

$\mathrm{H}-\mathrm{W}$ disequilibrium can result from any condition related to nonrandom mating, such as population subdivision. One common cause of $\mathrm{H}-\mathrm{W}$ disequilibrium is the existence of a null allele, which results in a deficit of heterozygotes. Null alleles refer to mutations in the primer regions flanking the microsatellite sequence, which result in a lack of amplification. Individuals that fail to amplify may be homozygous for a null allele, and some individuals that appear to be homozygotes may in fact be heterozygous for the observed allele and the null allele.

Linkage disequilibrium refers to the nonrandom association of loci, such that individuals with a particular genotype at one locus will tend to have a certain genotype at a different locus. Linkage disequilibrium can result when loci are physically linked: they are close together on the chromosome, such that recombination during meiosis does not 
often split them apart. However, linkage is not always physical, and can have a number of other causes. Linkage disequilibrium is problematic because it means that loci are not independent of one another, and therefore should not be treated as independent replicates. Most tests of genetic differentiation and gene flow assume that there is no linkage equilibrium and treat loci as if they were independent.

Linkage disequilibrium can result from actual physical linkage of loci that are close together on the chromosome, but there are several other possible causes. First, genetic drift in small populations can cause nonrandom associations between gametes. Second, although microsatellites are neutral, non-coding regions, natural selection may operate on an adjacent region, resulting in genetic hitchhiking of the microsatellite and apparent linkage. Third, subdivision within the defined population can result in linkage disequilibrium, if alleles are not mixing and recombining at random. In this case, genetic structure may suggest different population boundaries than those chosen by the researcher. Finally, sampling family groups may be a common cause of linkage disequilibrium. 


\section{APPENDIX 6 - MEASURING GENETIC DIFFERENTIATION \\ Genetic Distance: Wright's F $_{\text {ST }}$}

$\mathrm{F}_{\mathrm{ST}}$ is defined as the loss of heterozygosity due to population subdivision (Wright 1951). It is also the proportion of total genetic variation that exists among subpopulations (as opposed to within subpopulations). $\mathrm{F}_{\mathrm{ST}}$ ranges from 0 to 1 , with low $\mathrm{F}_{\mathrm{ST}}$ indicating high gene flow, and high $\mathrm{F}_{\mathrm{ST}}$ indicating low gene flow. Sewell Wright (1969) showed that $\mathrm{F}_{\mathrm{ST}} \approx 1 /(4 \mathrm{mN}+1)$ when the migration rate $(\mathrm{m})$ is very small. The amount of divergence among subpopulations depends only on the total number of migrants $(\mathrm{mN})$, not the migration rate $(\mathrm{m})$ (Allendorf and Phelps 1981). $\mathrm{G}_{\mathrm{ST}}$ is the multiple alleles version of $\mathrm{F}_{\mathrm{ST}}$, which was modeled for a 2-allele locus (Nei 1972). Weir and Cockerham (1984) created a commonly used estimate for $\mathrm{F}_{\mathrm{ST}}\left(\theta_{\mathrm{WC}}\right)$.

$\mathrm{F}_{\mathrm{ST}}$ is a useful statistic, but it is flawed in several ways that are especially relevant to microsatellites and populations experiencing recent changes. First, $\mathrm{F}_{\mathrm{ST}}$ is built on the island model of migration, which assumes that migration is equal between all subpopulations. This is obviously an invalid assumption, and we predicted that the opposite would in fact be true, that populations separated by highways would have lower migration between them. However, $\mathrm{F}_{\mathrm{ST}}$ is fairly robust to violations of this assumption (Mills and Allendorf 1996).

Second, Charlesworth (1998) and Hedrick (1999) observed that because microsatellite loci often have very high within-population heterozygosity, the magnitude of differentiation measures can be quite small. This is because $\mathrm{F}_{\mathrm{ST}}$ and similar measures are strongly influenced by the level of within-population diversity (which is often high with microsatellites), such that the proportion of diversity between populations (= genetic 
distance) is constrained to be small even when divergence is high, and must be smaller than overall homozygosity (Charlesworth 1998; Hedrick 1999). Slatkin (1995) noted that $\mathrm{F}_{\text {ST }}$ will tend to indicate genetic similarity even when this conclusion is not justified, because there is memory in the mutation process (Appendix 4) indicated by the SMM, which constrains the differentiation that can occur more than is implied by measures based on the IAM. Like $\mathrm{F}_{\mathrm{ST}}$, the maximum value of $\mathrm{G}_{\mathrm{ST}}$ may be quite small and must be less than the average within-population homozygosity.

Finally, $\mathrm{F}_{\mathrm{ST}}$ assumes migration drift equilibrium. The primary factors affecting genetic variation in recently subdivided populations are gene flow, which tends to keep populations from becoming differentiated, and genetic drift, which promotes differentiation (divergence). $\mathrm{F}_{\mathrm{ST}}$-type measures assume that the population has already reached genetic equilibrium between migration and drift, but this can take many generations if the population size is large and/or the migration rate is small (Varvio et al. 1986; Steinberg and Jordan 1997; Whitlock and McCauley 1999).

Numerous geneticists have formulated their own measures of genetic distance (Wright 1931, 1951, 1969; Cavalli-Sforza and Edwards 1967; Nei 1972; Weir and Cockerham 1984; Slatkin 1985; Chakraborty and Jin 1993; Goldstein et al. 1995a, b; Slatkin 1995; Shriver 1997), and most if not all of these measures have later been criticized by other geneticists (Goldstein et al. 1995a, b; Slatkin 1995; Takezaki and Nei 1996; Charlesworth 1998; Nagylaki 1998; Hedrick 1999). For example, Nagylaki (1998) concludes that $\mathrm{F}_{\mathrm{ST}}$ is an appropriate index of genetic differentiation only if genetic diversity is low. Nevertheless, conclusions reached by considering $F_{\text {ST }}$ are often similar 
to conclusions reached by consideration of other distance measures (Paetkau et al. 1997; Firestone et al. 2000), and no distance method is immune to all problems.

One alternative suggested by Hedrick (1999) is Slatkin's rare alleles method. However, Slatkin himself admitted that his rare alleles method, which says that the number of migrants per generation is linearly related to the logarithm of the average frequency of private (unshared) alleles (Slatkin 1985), is vulnerable to sampling problems. This occurs because a rare allele determined to be absent from a particular population may simply have been missed (Slatkin 1995). Steinberg and Jordan (1997) also noted that a private allele could result from the miscoding of a more common allele. Slatkin created another alternative to $\mathrm{F}_{\mathrm{ST}}$ called $\mathrm{R}_{\mathrm{ST}}$ (1995), Goldstein et al. $\left(1995_{\mathrm{b}}\right)$ created $(\delta \mu)^{2}$, and Shriver et al. (1997) created another statistic, all designed specifically for microsatellites under the SMM. Although these SMM distance methods appear to be more appropriate than distance measures designed earlier under IAM, SMM distances tend to perform more poorly than IAM distances (Paetkau et al. 1997), presumably because of the higher variance associated with SMM statistics (Paetkau et al. 1997; Balloux and Lugon-Moulin 2002). These authors found IAM statistics like $\mathrm{F}_{\mathrm{ST}}$ to be more sensitive to more recent divergence, while SMM statistics better reflected much older splits (i.e., for phylogenetic inference). We chose to use $\mathrm{F}_{\mathrm{ST}}$ because interpretation is straightforward, fragmentation by highways is recent, and $\mathrm{F}_{\mathrm{ST}}$ is commonly used in studies of population structure and fragmentation, facilitating comparisons between studies.

For reasons discussed above, assignment tests may be a more reliable measure of population differentiation and gene flow than $\mathrm{F}_{\mathrm{ST}}$. However, the assignment test relies 
upon genetic differences among populations, as quantified by $\mathrm{F}_{\mathrm{ST}}$, in order to correctly assign individuals, making these methods complementary.

\section{Assignment Test}

The assignment test is a relatively new method for assessing gene flow (Paetkau et al. 1995; Waser and Strobeck 1998). The assignment test attempts to assign captured individuals to their population of origin based on their genotype, considering genotype frequencies in all sampled populations. The individual is assigned to the population where its expected frequency is highest, where it has the greatest probability of occurrence. If the test consistently does this successfully, low gene flow is inferred. Whereas $\mathrm{F}_{\mathrm{ST}}$-type measures quantify genetic distance that has resulted from past levels of gene flow, the assignment test provides more current estimates, theoretically identifying migrants and quantifying current gene flow.

The assignment test as originally designed by Paetkau et al. (1995) assigns individuals according to their genotype through the following procedure (Waser and Strobeck 1998):

1) Remove the test individual's genotype from the population in which it was sampled and estimate allele frequencies at each locus.

2) Calculate the genotype's expected frequency in the population of capture at each locus.

3) Multiply across loci and log-transform the product.

4) Repeat to estimate the genotype's expected frequency in other potential source populations. 
5) Assign the genotype to the population in which it has the highest log-likelihood of occurrence.

Since 1995, other assignment methods have been developed (Rannala and Mountain 1997; Cornuet et al. 1999; Pritchard et al. 2000). The frequency-based likelihood assignment test corrects for apparently unique alleles by adding the unique allele to all populations at a small frequency, while Bayesian and distance-based assignment avoid this problem altogether.

Assignment tests can be broken down into two basic categories: likelihood-based assignment and distance-based assignment. Paetkau et al. (1995), Rannala and Mountain (1997), and Pritchard et al. (2000) all described different likelihood-based assignment methods. Paetkau et al. (1995) were the first to describe assignment tests as they are currently used (but Bowcock et al. (1994) and Estoup et al. (1995) used a similar sharedallele index). Although the frequency-based assignment methodology has been refined since 1995, the basic idea remains the same: individuals are assigned where their expected genotype frequency is highest (highest likelihood of occurrence). The Bayesian assignment method of Rannala and Mountain (1997) is similar, but incorporates Bayesian probabilities. Pritchard et al. (2000) developed the Bayesian clustering method, which allows users to choose whether or not to include "prior knowledge" of where an individual was captured, and considers all individuals simultaneously. This method is particularly useful when there is no prior information on population structure that would facilitate the determination of population boundaries. In this study, the Bayesian clustering method did not seem particularly useful, since we were not trying to determine 
the genetic structure of small mammals in western Montana, but were instead testing the specific hypothesis that highways form population boundaries.

Distance-based assignment methods (Cornuet et al. 1999) calculate the genetic distance between a given individual and all other individuals in each population. Individuals are assigned where the average genetic distance is lowest. The major advantage to this method is that Hardy-Weinberg and linkage equilibrium are not assumed or required. Within GeneClass (Cornuet et al. 1999), it is possible to assign individuals based on several distance statistics: Nei $\mathrm{D}_{\mathrm{A}}$, Nei Standard, and Nei Minimum (reviewed in Nei 1987), Cavalli-Sforza (Cavalli-Sforza and Edwards 1967), $\mathrm{D}_{\mathrm{AS}}$, shared allele distance (Chakraborty and Jin 1993), and Goldstein's distance (Goldstein et al. $1995_{\mathrm{b}}$ ). Cornuet et al. (1999) evaluated these methods and compared them to the likelihood assignment methods, varying time of population divergence, mutation model, sample size, and number of loci. They found that likelihood-based methods, particularly the Bayesian method, always outperformed distance assignment methods. All assignment methods performed better when the mutation model was the Infinite Alleles Model (IAM), as opposed to the Stepwise Mutation Model (SMM), when sample size and number of loci were higher, and when $\mathrm{F}_{\mathrm{ST}}$ was larger.

When first considering which assignment test to use, we tested a variety of options within GeneClass to assign individuals to their site of origin (sites were separated by $50-320 \mathrm{~km}, 30$ - 200 miles): the frequency-based likelihood method of Paetkau et al. (1995), the Bayesian likelihood method of Rannala and Mountain (1997), and several distance-based assignment methods (Cornuet et al.1999). In theory, no individuals should have misassigned, since small mammals do not disperse over such large distances. 
We found little variation in the proportion of individuals correctly assigned, except that Goldstein's distance statistic performed badly. The Bayesian likelihood method tended to perform best across our red-backed voles, deer mice, and vagrant shrews. Cornuet et al. (1999) also reported that the Bayesian likelihood method performed best on a simulated dataset. Because of superior performance, we used the Bayesian method both with and without loci that violated the Hardy-Weinberg assumption. For comparison, we also conducted assignment tests using distance assignment (Cornuet et al. 1999) based on Nei's $D_{A}$ distance statistic, because distance-based assignment does not assume H-W or linkage equilibrium.

In practice, our choice of assignment method had little impact on conclusions (Tables 3 -6; Appendix 10). For example, when assigning vagrant shrews to their site of origin, the Bayesian likelihood method correctly assigned $75-77 \%$ of individuals, depending on the number of loci used, with highest accuracy when all loci were used. The frequency-based likelihood method correctly assigned $73-77 \%$, depending on both the number of loci used and the constant value assumed for null frequencies. Nei's $\mathrm{D}_{\mathrm{A}}$ and the Cavalli-Sforza distance statistic correctly assigned $74-75 \%$, while the other distance measures $\left(\mathrm{D}_{\mathrm{AS}}\right.$, Nei Standard, and Nei minimum) had slightly lower accuracy, around $70 \%$, and Goldstein's method correctly assigned only $31 \%$ of individuals. This is an interesting result, considering that Goldstein's method was developed especially for microsatellites.

One major advantage is that the assignment test does not assume genetic equilibrium between migration and drift. It does, however, assume that the population is in Hardy-Weinberg equilibrium and that there is no linkage disequilibrium (with the 
exception of distance-based assignment: Cornuet et al. 1999). One potential problem with the assignment test that we encountered in this study is related to the fact that we artificially designated populations as those animals living in and around our trapping grids. The populations in our grids are adjacent to contiguous forest, with the exception of the edge bordering the highway. Thus, we did not sample throughout the true population, and the assignment test likely had difficulty assigning individuals to their population of origin simply because it was not covered by trapping grids. In part, we were able to get around this potential problem because we were not actually concerned with true population structure across the landscape; we were interested only in how highways affect population structure. Therefore, we have related misassignment rates adjacent to highways to misassignment rates across highways, providing a basis for comparison. A second issue to consider is that assignment tests tend to be inaccurate when populations are not distinct. Power is improved by testing more individuals at more loci (Rannala and Mountain 1997; Cornuet et al. 1999). 


\section{APPENDIX 7 - CAPTURES AND MOVEMENT}

\section{Individuals captured}

\begin{tabular}{lr}
\hline Species & Individuals \\
\cline { 2 - 2 } Deer mice & 504 \\
Vagrant shrews & 355 \\
Southern red-backed voles & 318 \\
Red-tailed chipmunks & 138 \\
Yellow pine chipmunks & 95 \\
Masked shrews & 59 \\
Western jumping mice & 44 \\
Meadow voles & 25 \\
Shrews spp.* & 19 \\
Chipmunks spp. ${ }^{*}$ & 14 \\
Bushy-tailed woodrats & 13 \\
Short-tailed weasels & 8 \\
Montane shrews & 7 \\
Northern flying squirrels & 6 \\
Pygmy shrews & 2 \\
Golden-mantled ground squirrels & 1 \\
Northern pocket gophers & 1 \\
Total Individuals & $\mathbf{1 6 0 9}$
\end{tabular}

Table 7.1. Number of individuals captured per species.

* Some chipmunks could not be identified to species due to indistinct coloration, and some shrews could not be identified due to worn teeth. 


\section{Individuals that moved}

\begin{tabular}{|l|c|c|c|c|c|c|}
\hline & \multicolumn{3}{|c|}{ 2-lane highways } & \multicolumn{3}{c|}{ 4-lane highways } \\
\cline { 2 - 7 } & $\begin{array}{c}\text { Total } \\
\text { Captured }\end{array}$ & $\begin{array}{c}\text { Moved } \\
\text { Adjacent }\end{array}$ & $\begin{array}{c}\text { Moved } \\
\text { Across }\end{array}$ & $\begin{array}{c}\text { Total } \\
\text { Captured }\end{array}$ & $\begin{array}{c}\text { Moved } \\
\text { Adjacent }\end{array}$ & $\begin{array}{c}\text { Moved } \\
\text { Across }\end{array}$ \\
\cline { 2 - 7 } RB voles & 157 & 8 & 1 & 139 & 1 & 1 \\
Deer mice & 88 & 5 & 9 & 414 & 29 & 11 \\
Chipmunks & 123 & 17 & 5 & 123 & 9 & 0 \\
All species & 368 & 30 & 15 & 676 & 39 & 12 \\
\hline
\end{tabular}

Table 7.2. Total number of individuals captured and released, as well as those that moved between highway trapping grids. Individuals that were dead in trap upon first capture are not included, since it wasn't possible to detect movement.

\section{Movement adjacent to versus across highways}

\begin{tabular}{|l|c|c|c|c|c|c|}
\hline & \multicolumn{4}{|c|}{ 2-lane highways } & \multicolumn{3}{c|}{ 4-lane highways } \\
\cline { 2 - 7 } & affected? & $\chi^{2}$ & $\mathrm{p}$-value & affected? & $\chi^{2}$ & - \\
\cline { 2 - 7 } RB voles & $\mathrm{Y}$ & 5.44 & $0.010<\mathrm{p}<0.025$ & $\mathrm{~N} / \mathrm{A}^{*}$ & - & $\mathrm{Y}$ \\
Deer mice & $\mathrm{N}$ & 1.14 & $\mathrm{p}>0.100$ & $\mathrm{Y}$ & 8.10 & $0.001<\mathrm{p}<0.005$ \\
Chipmunks & $\mathrm{Y}$ & 6.55 & $0.010<\mathrm{p}<0.025$ & $\mathrm{Y}$ & 9.00 & $0.001<\mathrm{p}<0.005$ \\
All species & $\mathrm{Y}$ & 5.00 & $0.025<\mathrm{p}<0.050$ & $\mathrm{Y}$ & 7.15 & $0.005<\mathrm{p}<0.010$ \\
\hline
\end{tabular}

Table 7.3. A chi-square test was used to compare the number of individuals moving between trapping grids adjacent to the highway versus across the highway. The null hypothesis was that movement was equal adjacent to and across highways. ${ }^{*}$ Small sample size of individuals moving between trapping grids (one vole moved between grids on the same and opposite sides of the highway) precluded testing. 


\section{APPENDIX 8 - GENETIC TESTS}

\section{$\underline{\text { Red-backed voles }}$}

Population differentiation among 2000 and 2001 red-backed vole samples

\begin{tabular}{|l|r|r|r|}
\hline Site & Locus & p-value & SE \\
\hline Lubrecht & 15 & 0.034 & 0.000 \\
\hline St. Regis & 15 & 0.047 & 0.001 \\
\hline
\end{tabular}

Table 8.1. Tests indicating population differentiation among 2000 and 2001 samples where $\alpha=0.5$. $2 / 24$ tests were significant when considered individually, but none were significant after a sequential Bonferroni correction for multiple tests.

Tests indicating Hardy-Weinberg disequilibrium for red-backed voles

\begin{tabular}{|l|l|r|r|r|}
\hline Site & Grid & Locus & p-value & SE \\
\hline Lolo & SE & 6 & $* 0.012$ & 0.000 \\
\hline Rainy & SE & 15 & 0.042 & 0.001 \\
\hline Rainy & SW & 6 & $* 0.000$ & 0.000 \\
\hline Rainy & SW & $4 \mathrm{~B}$ & $* 0.007$ & 0.000 \\
\hline St. Regis & NE1 & 4 & 0.037 & 0.001 \\
\hline St. Regis & NE1 & 15 & $* 0.007$ & 0.000 \\
\hline St. Regis & NW & 5 & 0.011 & 0.001 \\
\hline St. Regis & NW & 6 & $* 0.000$ & 0.000 \\
\hline St. Regis & NW & $4 \mathrm{~B}$ & 0.047 & 0.002 \\
\hline St. Regis & SE & 4 & 0.035 & 0.001 \\
\hline St. Regis & SW & 6 & $* 0.000$ & 0.000 \\
\hline
\end{tabular}

Table 8.2. Tests indicating H-W disequilibrium among voles where $\alpha=0.05$. There were 17 tests per locus. ${ }^{*} \mathrm{p}<0.05$ after sequential Bonferroni procedure 
Tests indicating linkage disequilibrium for red-backed voles

\begin{tabular}{|c|c|c|c|c|c|}
\hline Site & Grid & Locus 1 & Locus 2 & p-value & SE \\
\hline Lubrecht & SW & 19 & 4 & $* 0.004$ & 0.000 \\
\hline Lubrecht & SW & 19 & 5 & $* 0.001$ & 0.000 \\
\hline Lubrecht & SE & 19 & $4 \mathrm{~B}$ & 0.038 & 0.000 \\
\hline Lubrecht & SW & 4B & 4 & $* 0.004$ & 0.000 \\
\hline Lubrecht & SW & $4 \mathrm{~B}$ & 5 & $* 0.006$ & 0.000 \\
\hline Lubrecht & SW & $4 B$ & 15 & $* 0.007$ & 0.000 \\
\hline Lubrecht & SW & 4 & 5 & $* 0.001$ & 0.000 \\
\hline Lubrecht & SW & 4 & 15 & 0.038 & 0.002 \\
\hline Lubrecht & SW & 5 & 15 & $* 0.003$ & 0.000 \\
\hline Rainy & NW & 5 & 6 & 0.046 & 0.001 \\
\hline Rainy & SW & 5 & 6 & 0.038 & 0.001 \\
\hline Rainy & $\mathrm{SE}$ & 19 & 15 & $* 0.011$ & 0.001 \\
\hline Rainy & NW & 4 & 15 & 0.023 & 0.002 \\
\hline Rainy & $\mathrm{SE}$ & 4 & 15 & 0.015 & 0.001 \\
\hline Rainy & $\mathrm{SE}$ & 6 & $4 \mathrm{~B}$ & 0.041 & 0.000 \\
\hline Rainy & SW & 6 & $4 B$ & 0.030 & 0.001 \\
\hline St. Regis & NE1 & 4B & 5 & 0.036 & 0.001 \\
\hline St. Regis & NW & $4 \mathrm{~B}$ & 5 & 0.010 & 0.001 \\
\hline St. Regis & SW & 5 & 19 & 0.038 & 0.003 \\
\hline St. Regis & NW & 15 & 6 & 0.022 & 0.001 \\
\hline St. Regis & SW & 19 & 6 & $* 0.000$ & 0.000 \\
\hline
\end{tabular}

Table 8.3. Tests indicating linkage disequilibrium among voles where $\alpha=0.05$. There were $14-17$ tests per locus pair, depending on sample size and variation at those loci in each trapping grid. $* \mathrm{p}<0.05$ after sequential Bonferroni procedure 
$\%$ of tests in which linkage disequilibrium was detected for red-backed voles

\begin{tabular}{|r|r|r|r|r|r|r|r|}
\hline Locus 1 & Locus 2 & Lolo & Lubrecht & Rainy & St. Regis & Total & \% \\
\hline 4 & 5 & 0 & 1 & 0 & 0 & 1 & 7.1 \\
\hline 4 & 15 & 0 & 1 & 2 & 0 & 3 & 20.0 \\
\hline 4 & 19 & 0 & 1 & 0 & 0 & 1 & 6.3 \\
\hline 4 & 6 & 0 & 0 & 0 & 0 & 0 & 0 \\
\hline 4 & $4 \mathrm{~B}$ & 0 & 1 & 0 & 0 & 1 & 6.3 \\
\hline 5 & 15 & 0 & 1 & 0 & 0 & 1 & 7.1 \\
\hline 5 & 19 & 0 & 1 & 0 & 1 & 2 & 21.4 \\
\hline 5 & 6 & 0 & 0 & 2 & 0 & 2 & 14.3 \\
\hline 5 & $4 \mathrm{~B}$ & 0 & 1 & 0 & 2 & 3 & 21.4 \\
\hline 15 & 19 & 0 & 0 & 1 & 0 & 1 & 6.3 \\
\hline 15 & 6 & 0 & 0 & 0 & 1 & 1 & 5.9 \\
\hline 15 & $4 \mathrm{~B}$ & 0 & 1 & 0 & 0 & 1 & 6.3 \\
\hline 19 & 6 & 0 & 0 & 0 & 1 & 1 & 11.8 \\
\hline 19 & $4 \mathrm{~B}$ & 0 & 1 & 0 & 0 & 1 & 5.9 \\
\hline 6 & $4 \mathrm{~B}$ & 0 & 0 & 2 & 0 & 2 & 11.8 \\
\hline Total & & 0 & 9 & 7 & 5 & $\mathbf{2 1}$ & \\
\hline$\%$ & & 0 & 16.4 & 11.7 & 5.6 & & $\mathbf{9 . 3}$ \\
\hline 8
\end{tabular}

Table 8.4. Percentage of times linkage disequilibrium was detected for red-backed voles when $\alpha=0.05$. 


\section{$\underline{\text { Deer Mice }}$}

Population differentiation among 2000 and 2001 deer mouse samples

\begin{tabular}{|l|r|r|r|}
\hline Site & Locus & p-value & SE \\
\hline Lubrecht & 6 & $* 0.005$ & 0.000 \\
\hline Lubrecht & 5 & 0.047 & 0.000 \\
\hline Lubrecht & 10 & $* 0.009$ & 0.000 \\
\hline Lubrecht & 12 & 0.037 & 0.000 \\
\hline St. Regis & 1 & $* 0.021$ & 0.000 \\
\hline St. Regis & 6 & $* 0.000$ & 0.000 \\
\hline St. Regis & 5 & $* 0.000$ & 0.000 \\
\hline St. Regis & 10 & $* 0.003$ & 0.000 \\
\hline St. Regis & 12 & $* 0.003$ & 0.000 \\
\hline Tarkio & 1 & $* 0.001$ & 0.000 \\
\hline Tarkio & 4 & 0.043 & 0.001 \\
\hline Tarkio & 5 & $* 0.000$ & 0.000 \\
\hline Tarkio & 12 & $* 0.000$ & 0.000 \\
\hline
\end{tabular}

Table 8.5. Tests indicating population differentiation among 2000 and 2001 samples where $\alpha=0.5$. 13/18 tests were significant when considered individually, and 10/18 remained significant after a sequential

Bonferroni correction for multiple tests. ${ }^{*} \mathrm{p}<0.05$ after sequential Bonferroni procedure

Tests indicating Hardy-Weinberg disequilibrium for deer mice

\begin{tabular}{|c|c|c|c|c|}
\hline Site & Grid & Locus & p-value & SE \\
\hline Lubrecht & $\mathrm{NE}$ & 5 & 0.048 & 0.001 \\
\hline Lubrecht & NW & 1 & $* 0.002$ & 0.000 \\
\hline Lubrecht & NW & 6 & $* 0.010$ & 0.001 \\
\hline Lubrecht & NW & 10 & $* 0.000$ & 0.000 \\
\hline Lubrecht & $\mathrm{SE}$ & 1 & 0.048 & 0.001 \\
\hline Lubrecht & $\mathrm{SE}$ & 10 & $* 0.010$ & 0.000 \\
\hline Lubrecht & SW & 1 & 0.035 & 0.001 \\
\hline Lubrecht & SW & 4 & 0.042 & 0.001 \\
\hline Lubrecht & SW & 10 & $* 0.000$ & 0.000 \\
\hline St. Regis 2000 & $\mathrm{NE}$ & 4 & 0.014 & 0.000 \\
\hline St. Regis 2000 & $\mathrm{NE}$ & 10 & $* 0.047$ & 0.001 \\
\hline St. Regis2000 & NW & 1 & $* 0.000$ & 0.000 \\
\hline St. Regis 2000 & NW & 10 & $* 0.000$ & 0.000 \\
\hline St. Regis 2000 & $\mathrm{SE}$ & 10 & $* 0.018$ & 0.000 \\
\hline St. Regis2000 & SW & 10 & $* 0.000$ & 0.000 \\
\hline St. Regis2001 & $\mathrm{NE}$ & 1 & $* 0.000$ & 0.000 \\
\hline St. Regis2001 & $\mathrm{NE}$ & 6 & $* 0.002$ & 0.000 \\
\hline St. Regis2001 & $\mathrm{NE}$ & 4 & $* 0.001$ & 0.000 \\
\hline St. Regis2001 & $\mathrm{NE}$ & 5 & $* 0.000$ & 0.000 \\
\hline St. Regis2001 & $\mathrm{NE}$ & 10 & $* 0.000$ & 0.000 \\
\hline St. Regis2001 & NW & 1 & $* 0.000$ & 0.000 \\
\hline St. Regis2001 & NW & 10 & $* 0.008$ & 0.000 \\
\hline
\end{tabular}




\begin{tabular}{|c|c|c|c|c|}
\hline Site & Grid & Locus & p-value & SE \\
\hline St. Regis2001 & NW & 12 & $* 0.008$ & 0.000 \\
\hline St. Regis2001 & NW1 & 1 & $* 0.013$ & 0.000 \\
\hline St. Regis2001 & SE & 1 & $* 0.004$ & 0.000 \\
\hline St. Regis2001 & SE & 4 & $* 0.003$ & 0.000 \\
\hline St. Regis2001 & SE & 5 & $* 0.003$ & 0.000 \\
\hline St. Regis2001 & SE & 10 & $* 0.000$ & 0.000 \\
\hline St. Regis2001 & SE & 12 & 0.017 & 0.000 \\
\hline St. Regis2001 & SW & 1 & $* 0.012$ & 0.001 \\
\hline St. Regis2001 & SW & 6 & $* 0.000$ & 0.000 \\
\hline St. Regis2001 & SW & 5 & 0.042 & 0.001 \\
\hline St. Regis2001 & SW & 10 & $* 0.000$ & 0.000 \\
\hline Tarkio2000 & $\mathrm{NE}$ & 1 & $* 0.024$ & 0.001 \\
\hline Tarkio2000 & $\mathrm{NE}$ & 6 & 0.015 & 0.001 \\
\hline Tarkio2000 & $\mathrm{NE}$ & 10 & $* 0.000$ & 0.000 \\
\hline Tarkio2000 & NW & 1 & $* 0.000$ & 0.000 \\
\hline Tarkio2000 & NW & 4 & 0.031 & 0.001 \\
\hline Tarkio2000 & NW & 10 & $* 0.000$ & 0.000 \\
\hline Tarkio2000 & SE & 1 & $* 0.003$ & 0.000 \\
\hline Tarkio2000 & SE & 5 & $* 0.000$ & 0.000 \\
\hline Tarkio2000 & SE & 10 & $* 0.000$ & 0.000 \\
\hline Tarkio2000 & SW & 1 & $* 0.000$ & 0.000 \\
\hline Tarkio2000 & SW & 6 & 0.043 & 0.002 \\
\hline Tarkio2000 & SW & 10 & $* 0.000$ & 0.000 \\
\hline Tarkio2001 & NE & 1 & $* 0.000$ & 0.000 \\
\hline Tarkio2001 & $\mathrm{NE}$ & 6 & 0.021 & 0.001 \\
\hline Tarkio2001 & $\mathrm{NE}$ & 10 & $* 0.000$ & 0.000 \\
\hline Tarkio2001 & $\mathrm{NE}$ & 12 & $* 0.000$ & 0.000 \\
\hline Tarkio2001 & NW & 1 & $* 0.000$ & 0.000 \\
\hline Tarkio2001 & NW & 6 & $* 0.004$ & 0.001 \\
\hline Tarkio2001 & NW & 4 & $* 0.003$ & 0.000 \\
\hline Tarkio2001 & NW & 5 & 0.013 & 0.001 \\
\hline Tarkio2001 & NW & 10 & $* 0.000$ & 0.000 \\
\hline Tarkio2001 & SE & 1 & $* 0.017$ & 0.00 \\
\hline Tarkio2001 & SE & 6 & 0.039 & 0.002 \\
\hline Tarkio2001 & SE & 10 & $* 0.000$ & 0.000 \\
\hline Tarkio2001 & SE & 12 & 0.036 & 0.001 \\
\hline Tarkio2001 & SW & 1 & $* 0.013$ & 0.001 \\
\hline Tarkio2001 & SW & 10 & $* 0.000$ & 0.000 \\
\hline
\end{tabular}

Table 8.6. Tests indicating H-W disequilibrium among mice where $\alpha=0.05$. There were 22 tests per locus. $* \mathrm{p}<0.05$ after sequential Bonferroni procedure 
Tests indicating linkage disequilibrium for deer mice

\begin{tabular}{|c|c|c|c|c|c|}
\hline Site & Grid & Locus 1 & Locus 2 & p-value & SE \\
\hline Lubrecht & NW & 6 & 4 & 0.042 & 0.002 \\
\hline Lubrecht & NW & 6 & 5 & 0.038 & 0.002 \\
\hline Lubrecht & NW & 4 & 5 & 0.013 & 0.001 \\
\hline Lubrecht & NW & 10 & 12 & $* 0.003$ & 0.000 \\
\hline St. Regis 2000 & $\mathrm{NE}$ & 4 & 5 & 0.042 & 0.003 \\
\hline St. Regis 2000 & $\mathrm{NE}$ & 6 & 12 & 0.031 & 0.002 \\
\hline St. Regis 2000 & SW & 6 & 5 & 0.040 & 0.003 \\
\hline St. Regis2001 & $\mathrm{NE}$ & 6 & 4 & $* 0.008$ & 0.001 \\
\hline St. Regis 2001 & $\mathrm{NE}$ & 6 & 5 & $* 0.005$ & 0.000 \\
\hline St. Regis2001 & $\mathrm{NE}$ & 4 & 5 & $* 0.000$ & 0.000 \\
\hline St. Regis2001 & $\mathrm{NE}$ & 6 & 12 & $* 0.000$ & 0.000 \\
\hline St. Regis 2001 & $\mathrm{NE}$ & 4 & 12 & $* 0.013$ & 0.001 \\
\hline St. Regis2001 & $\mathrm{NE}$ & 5 & 12 & $* 0.003$ & 0.000 \\
\hline St. Regis2001 & $\mathrm{NE}$ & 10 & 12 & $* 0.013$ & 0.001 \\
\hline St. Regis 2001 & NW & 4 & 5 & $* 0.000$ & 0.000 \\
\hline St. Regis2001 & NW & 4 & 10 & 0.0137 & 0.001 \\
\hline St. Regis2001 & NW1 & 4 & 5 & $* 0.028$ & 0.001 \\
\hline St. Regis 2001 & $\mathrm{SE}$ & 1 & 4 & $* 0.008$ & 0.001 \\
\hline St. Regis2001 & $\mathrm{SE}$ & 6 & 4 & $* 0.000$ & 0.000 \\
\hline St. Regis2001 & $\mathrm{SE}$ & 1 & 5 & $* 0.003$ & 0.001 \\
\hline St. Regis2001 & SE & 4 & 5 & $* 0.000$ & 0.000 \\
\hline St. Regis2001 & $\mathrm{SE}$ & 1 & 10 & 0.040 & 0.002 \\
\hline St. Regis2001 & $\mathrm{SE}$ & 4 & 12 & $* 0.001$ & 0.000 \\
\hline St. Regis2001 & $\mathrm{SE}$ & 5 & 12 & 0.032 & 0.002 \\
\hline St. Regis2001 & $\mathrm{SE}$ & 10 & 12 & $* 0.000$ & 0.000 \\
\hline St. Regis 2001 & SW & 1 & 6 & $* 0.000$ & 0.000 \\
\hline St. Regis2001 & SW & 6 & 4 & $* 0.000$ & 0.000 \\
\hline St. Regis2001 & SW & 6 & 5 & $* 0.002$ & 0.001 \\
\hline St. Regis2001 & SW & 4 & 5 & $* 0.000$ & 0.000 \\
\hline St. Regis2001 & SW & 6 & 12 & $* 0.007$ & 0.001 \\
\hline St. Regis2001 & SW & 4 & 12 & 0.030 & 0.003 \\
\hline Tarkio2000 & $\mathrm{NE}$ & 1 & 6 & $* 0.007$ & 0.001 \\
\hline Tarkio2000 & $\mathrm{NE}$ & 1 & 4 & 0.014 & 0.001 \\
\hline Tarkio2000 & $\mathrm{NE}$ & 6 & 4 & $* 0.001$ & 0.000 \\
\hline Tarkio2000 & $\mathrm{NE}$ & 1 & 5 & $* 0.013$ & 0.001 \\
\hline Tarkio2000 & $\mathrm{NE}$ & 6 & 5 & 0.047 & 0.002 \\
\hline Tarkio2000 & $\mathrm{NE}$ & 1 & 12 & $* 0.006$ & 0.001 \\
\hline Tarkio2000 & NW & 1 & 5 & $* 0.002$ & 0.001 \\
\hline Tarkio2000 & NW & 4 & 5 & $* 0.000$ & 0.000 \\
\hline Tarkio2000 & $\mathrm{SE}$ & 6 & 4 & $* 0.006$ & 0.001 \\
\hline Tarkio2000 & $\mathrm{SE}$ & 4 & 5 & $* 0.000$ & 0.000 \\
\hline Tarkio2000 & $\mathrm{SE}$ & 5 & 10 & 0.021 & 0.002 \\
\hline
\end{tabular}




\begin{tabular}{|c|c|c|c|c|c|}
\hline Site & Grid & Locus 1 & Locus 2 & p-value & SE \\
\hline Tarkio2000 & SW & 6 & 5 & 0.041 & 0.003 \\
\hline Tarkio2000 & SW & 4 & 5 & $* 0.013$ & 0.002 \\
\hline Tarkio2000 & SW & 10 & 12 & $* 0.002$ & 0.000 \\
\hline Tarkio2001 & $\mathrm{NE}$ & 1 & 6 & $* 0.000$ & 0.000 \\
\hline Tarkio2001 & $\mathrm{NE}$ & 1 & 4 & $* 0.021$ & 0.002 \\
\hline Tarkio2001 & $\mathrm{NE}$ & 1 & 5 & $* 0.000$ & 0.000 \\
\hline Tarkio2001 & $\mathrm{NE}$ & 4 & 5 & $* 0.000$ & 0.000 \\
\hline Tarkio2001 & $\mathrm{NE}$ & 1 & 10 & 0.015 & 0.002 \\
\hline Tarkio2001 & $\mathrm{NE}$ & 6 & 10 & $* 0.008$ & 0.001 \\
\hline Tarkio2001 & $\mathrm{NE}$ & 4 & 10 & $* 0.000$ & 0.000 \\
\hline Tarkio2001 & $\mathrm{NE}$ & 5 & 10 & $* 0.000$ & 0.000 \\
\hline Tarkio2001 & $\mathrm{NE}$ & 5 & 12 & $* 0.005$ & 0.001 \\
\hline Tarkio2001 & $\mathrm{NE}$ & 10 & 12 & 0.046 & 0.003 \\
\hline Tarkio2001 & NW & 1 & 6 & $* 0.000$ & 0.000 \\
\hline Tarkio2001 & NW & 1 & 4 & $* 0.000$ & 0.000 \\
\hline Tarkio2001 & NW & 6 & 4 & $* 0.001$ & 0.000 \\
\hline Tarkio2001 & NW & 1 & 5 & $* 0.000$ & 0.000 \\
\hline Tarkio2001 & NW & 6 & 5 & $* 0.002$ & 0.001 \\
\hline Tarkio2001 & NW & 4 & 5 & $* 0.000$ & 0.000 \\
\hline Tarkio2001 & NW & 1 & 10 & 0.045 & 0.004 \\
\hline Tarkio2001 & NW & 5 & 10 & 0.033 & 0.004 \\
\hline Tarkio2001 & NW & 1 & 12 & $* 0.002$ & 0.001 \\
\hline Tarkio2001 & NW & 6 & 12 & $* 0.000$ & 0.000 \\
\hline Tarkio2001 & NW & 4 & 12 & $* 0.000$ & 0.000 \\
\hline Tarkio2001 & NW & 5 & 12 & $* 0.000$ & 0.000 \\
\hline Tarkio2001 & NW & 10 & 12 & 0.037 & 0.004 \\
\hline Tarkio2001 & SE & 6 & 4 & $* 0.005$ & 0.001 \\
\hline Tarkio2001 & SE & 6 & 5 & $* 0.000$ & 0.000 \\
\hline Tarkio2001 & SE & 4 & 5 & $* 0.000$ & 0.000 \\
\hline Tarkio2001 & SE & 1 & 10 & 0.036 & 0.003 \\
\hline Tarkio2001 & SE & 6 & 10 & $* 0.005$ & 0.001 \\
\hline Tarkio2001 & SE & 4 & 10 & $* 0.000$ & 0.000 \\
\hline Tarkio2001 & SE & 5 & 10 & $* 0.003$ & 0.001 \\
\hline Tarkio2001 & SE & 6 & 12 & $* 0.007$ & 0.001 \\
\hline Tarkio2001 & SE & 10 & 12 & $* 0.004$ & 0.001 \\
\hline Tarkio2001 & SW & 1 & 6 & 0.030 & 0.003 \\
\hline Tarkio2001 & SW & 1 & 4 & $* 0.005$ & 0.001 \\
\hline Tarkio2001 & SW & 6 & 4 & $* 0.006$ & 0.002 \\
\hline Tarkio2001 & SW & 1 & 5 & 0.033 & 0.004 \\
\hline Tarkio2001 & SW & 6 & 5 & $* 0.021$ & 0.003 \\
\hline Tarkio2001 & SW & 4 & 5 & $* 0.000$ & 0.000 \\
\hline Tarkio2001 & SW & 1 & 12 & 0.046 & 0.004 \\
\hline Tarkio2001 & SW & 4 & 12 & $* 0.011$ & 0.002 \\
\hline
\end{tabular}




\begin{tabular}{|l|l|r|r|r|r|}
\hline Site & Grid & Locus 1 & Locus 2 & p-value & SE \\
\hline Tarkio2001 & SW & 5 & 12 & $* 0.011$ & 0.002 \\
\hline
\end{tabular}

Table 8.7. Tests indicating linkage disequilibrium among deer mice where $\alpha=0.05$. There were $17-20$ tests per locus pair, depending on sample size and variation at those loci in each trapping grid. ${ }^{*} \mathrm{p}<0.05$ after sequential Bonferroni procedure 
Percentage of tests in which linkage disequilibrium was detected for deer mice

\begin{tabular}{|c|c|c|c|c|c|c|c|c|}
\hline Locus 1 & Locus 2 & Lubrecht & $\begin{array}{c}\text { St. Regis } \\
2000\end{array}$ & $\begin{array}{c}\text { St. Regis } \\
2001\end{array}$ & $\begin{array}{c}\text { Tarkio } \\
\mathbf{2 0 0 0} \\
\end{array}$ & $\begin{array}{c}\text { Tarkio } \\
2001 \\
\end{array}$ & Total & $\%$ \\
\hline 1 & 6 & 0 & 0 & 1 & 1 & 3 & 5 & 29.4 \\
\hline 1 & 4 & 0 & 0 & 1 & 1 & 3 & 5 & 23.8 \\
\hline 1 & 5 & 0 & 0 & 1 & 2 & 3 & 6 & 30.0 \\
\hline 1 & 10 & 0 & 0 & 1 & 0 & 3 & 4 & 21.1 \\
\hline 1 & 12 & 0 & 0 & 0 & 1 & 2 & 3 & 16.7 \\
\hline 6 & 4 & 1 & 0 & 3 & 2 & 3 & 9 & 50.0 \\
\hline 6 & 5 & 1 & 1 & 2 & 2 & 3 & 9 & 52.9 \\
\hline 6 & 10 & 0 & 0 & 0 & 0 & 2 & 2 & 11.1 \\
\hline 6 & 12 & 0 & 1 & 2 & 0 & 2 & 5 & 27.8 \\
\hline 4 & 5 & 1 & 1 & 5 & 3 & 4 & 14 & 73.7 \\
\hline 4 & 10 & 0 & 0 & 1 & 0 & 2 & 3 & 16.7 \\
\hline 4 & 12 & 0 & 0 & 3 & 0 & 2 & 5 & 26.3 \\
\hline 5 & 10 & 0 & 0 & 0 & 1 & 3 & 4 & 22.2 \\
\hline 5 & 12 & 0 & 0 & 2 & 0 & 3 & 5 & 27.8 \\
\hline 10 & 12 & 1 & 0 & 2 & 1 & 3 & 7 & 41.8 \\
\hline Total & & 4 & 3 & 24 & 14 & 41 & 86 & \\
\hline$\%$ & & 10.8 & 8.1 & 35.8 & 23.3 & 68.3 & & 33.0 \\
\hline
\end{tabular}

Table 8.8. Percentage of times linkage disequilibrium was detected for deer mice when $\alpha=0.05$. 


\section{Vagrant shrews}

Population differentiation among 2000 and 2001 vagrant shrew samples

\begin{tabular}{|l|r|r|r|}
\hline Site & Locus & p-value & SE \\
\hline Lolo & A3-35 & 0.030 & 0.000 \\
\hline Rainy & A3-5 & $* 0.049$ & 0.000 \\
\hline Rainy & A3-35 & $* 0.009$ & 0.000 \\
\hline Rainy & A4-20 & $* 0.001$ & 0.000 \\
\hline Rainy & A4-5 & $* 0.002$ & 0.000 \\
\hline Rainy & SH-22 & $* 0.007$ & 0.000 \\
\hline St. Regis & A3-35 & $* 0.000$ & 0.000 \\
\hline
\end{tabular}

Table 8.9. Tests indicating population differentiation among 2000 and 2001 samples where $\alpha=0.5$. $7 / 15$ tests were significant when considered individually, including $5 / 5$ tests at Rainy Lake (due to large changes in small sample sizes from 2000 to 2001). 6/15 remained significant after a sequential Bonferroni correction for multiple tests. ${ }^{*} \mathrm{p}<0.05$ after sequential Bonferroni procedure

Tests indicating Hardy-Weinberg disequilibrium for vagrant shrews

\begin{tabular}{|c|c|c|c|c|}
\hline Site & Grid & Locus & p-value & SE \\
\hline Lolo & $\mathrm{NE}$ & A3-5 & $* 0.002$ & 0.000 \\
\hline Lolo & SE & A3-5 & $* 0.000$ & 0.000 \\
\hline Lolo & SW & A3-5 & $* 0.000$ & 0.000 \\
\hline Lolo & $\mathrm{NE}$ & A4-5 & 0.023 & 0.001 \\
\hline Lolo & $\mathrm{NE}$ & SH-22 & $* 0.002$ & 0.000 \\
\hline Lolo & $\mathrm{SE}$ & SH-22 & $* 0.017$ & 0.001 \\
\hline Lolo & SW & SH-22 & $* 0.000$ & 0.000 \\
\hline Rainy & NW & A3-5 & $* 0.001$ & 0.000 \\
\hline Rainy & NW & A3-35 & 0.026 & 0.000 \\
\hline Rainy & SW & A4-5 & $* 0.005$ & 0.001 \\
\hline St. Regis & $\mathrm{NE}$ & A3-5 & $* 0.000$ & 0.000 \\
\hline St. Regis & NE1 & A3-5 & $* 0.000$ & 0.000 \\
\hline St. Regis & NW & A3-5 & $* 0.000$ & 0.000 \\
\hline St. Regis & NW1 & A3-5 & $* 0.000$ & 0.000 \\
\hline St. Regis & $\mathrm{SE}$ & A3-5 & $* 0.000$ & 0.000 \\
\hline St. Regis & SW & A3-5 & $* 0.000$ & 0.000 \\
\hline St. Regis & NE1 & A4-5 & 0.048 & 0.002 \\
\hline St. Regis & NW & SH-22 & $* 0.000$ & 0.000 \\
\hline St. Regis & NW1 & SH-22 & $* 0.006$ & 0.000 \\
\hline St. Regis & $\mathrm{SE}$ & SH-22 & $* 0.002$ & 0.000 \\
\hline St. Regis & SW & SH-22 & $* 0.000$ & 0.000 \\
\hline
\end{tabular}

Table 8.10. Tests indicating H-W disequilibrium among shrews where $\alpha=0.05$. There were 12 tests per locus. $* \mathrm{p}<0.05$ after sequential Bonferroni procedure 
Tests indicating linkage disequilibrium for vagrant shrews

\begin{tabular}{|l|l|r|r|r|r|}
\hline Site & Grid & Locus 1 & Locus 2 & p-value & SE \\
\hline Rainy & SW & A3-5 & A4-20 & $* 0.023$ & 0.001 \\
\hline St. Regis & NE & A3-5 & A4-20 & 0.009 & 0.001 \\
\hline St. Regis & NW1 & A3-5 & A4-20 & 0.027 & 0.002 \\
\hline St. Regis & NE1 & A3-5 & A4-5 & 0.036 & 0.003 \\
\hline
\end{tabular}

Table 8.11. Tests indicating linkage disequilibrium among shrews where $\alpha=0.05$. There were $10-11$ tests per locus pair, depending on sample size and variation at those loci in each trapping grid. ${ }^{*} \mathrm{p}<0.05$ after sequential Bonferroni procedure 


\section{APPENDIX 9 - HETEROZYGOSITY AND ALLELIC DIVERSITY}

\section{Average heterozygosity for red-backed voles}

\begin{tabular}{|l|r|r|r|r|}
\hline Site & \multicolumn{2}{|c|}{ All loci } & \multicolumn{2}{|c|}{ w/out 6 } \\
\hline & Het exp & Het obs & Het exp & Het obs \\
\hline Lolo & $\mathbf{0 . 7 8 8}$ & 0.739 & $\mathbf{0 . 8 5 0}$ & 0.830 \\
\hline Lubrecht & $\mathbf{0 . 7 4 9}$ & 0.736 & 0.779 & $\mathbf{0 . 8 0 6}$ \\
\hline Rainy & 0.756 & $\mathbf{0 . 7 6 4}$ & 0.800 & $\mathbf{0 . 8 2 0}$ \\
\hline St. Regis & $\mathbf{0 . 7 5 5}$ & 0.731 & $\mathbf{0 . 8 3 6}$ & 0.821 \\
\hline Total & $\mathbf{0 . 7 6 2}$ & 0.742 & $\mathbf{0 . 8 1 6}$ & 0.819 \\
\hline
\end{tabular}

Table 9.1a. Heterozygosity was averaged over all six loci, and was then recalculated, leaving out locus 6. Locus 6 was out of Hardy-Weinberg equilibrium and exhibited a deficit of heterozygotes consistent with the existence of a null allele. Expected heterozygosity exceeded observed heterozygosity in most cases, but differences were quite small without locus $6 . \mathrm{F}_{\mathrm{ST}}$ has an upper limit equal to the average homozygosity: 0.234 calculated with locus 6 , and 0.184 calculated without locus 6 .

\section{Average heterozygosity for deer mice}

\begin{tabular}{|l|r|r|r|r|r|r|}
\hline Site & \multicolumn{2}{|c|}{ All loci } & \multicolumn{2}{c|}{ w/out 10} & \multicolumn{2}{c|}{ w/out 1 or 10 } \\
\hline & Het exp & Het obs & Het exp & Het obs & Het exp & Het obs \\
\hline Lubrecht & $\mathbf{0 . 9 1 4}$ & 0.753 & $\mathbf{0 . 9 1 4}$ & 0.842 & $\mathbf{0 . 9 2 2}$ & 0.911 \\
\hline Rainy & $\mathbf{0 . 8 9 7}$ & 0.875 & 0.908 & $\mathbf{0 . 9 2 4}$ & 0.914 & $\mathbf{0 . 9 4 8}$ \\
\hline St. Regis & $\mathbf{0 . 8 7 6}$ & 0.749 & $\mathbf{0 . 8 8 1}$ & 0.815 & $\mathbf{0 . 8 8 2}$ & 0.861 \\
\hline Tarkio & $\mathbf{0 . 9 0 8}$ & 0.790 & $\mathbf{0 . 9 1 8}$ & 0.859 & $\mathbf{0 . 9 1 8}$ & 0.905 \\
\hline Total & $\mathbf{0 . 8 9 9}$ & 0.792 & $\mathbf{0 . 9 0 5}$ & 0.860 & $\mathbf{0 . 9 0 9}$ & 0.906 \\
\hline
\end{tabular}

Table 9.1b. Heterozygosity was averaged over all six loci, and was then recalculated, leaving out locus 10 and leaving out both 1 and 10. These loci were out of Hardy-Weinberg equilibrium and exhibited a deficit of heterozygotes consistent with the existence of a null allele. Expected heterozygosity exceeded observed heterozygosity in most cases, but differences were quite small when only those loci in $\mathrm{H}-\mathrm{W}$ equilibrium were considered. $\mathrm{F}_{\mathrm{ST}}$ has an upper limit equal to the average homozygosity: 0.101 calculated with all loci, 0.095 without locus 10 , and 0.091 without 1 or 10 .

\section{Average heterozygosity for vagrant shrews}

\begin{tabular}{|l|r|r|r|r|r|r|}
\hline Site & \multicolumn{2}{|c|}{ All loci } & \multicolumn{2}{c|}{ w/out A3-5 } & \multicolumn{2}{c|}{ w/out A3-5 or SH-22 } \\
\hline & Het exp & Het obs & Het exp & Het obs & Het exp & Het obs \\
\hline Lolo & $\mathbf{0 . 8 5 7}$ & 0.693 & $\mathbf{0 . 8 4 8}$ & 0.758 & $\mathbf{0 . 8 6 5}$ & 0.840 \\
\hline Rainy & $\mathbf{0 . 8 8 0}$ & 0.720 & $\mathbf{0 . 8 7 7}$ & 0.750 & $\mathbf{0 . 8 9 6}$ & 0.782 \\
\hline St. Regis & $\mathbf{0 . 8 5 7}$ & 0.707 & $\mathbf{0 . 8 4 9}$ & 0.771 & $\mathbf{0 . 8 6 2}$ & 0.825 \\
\hline Total & $\mathbf{0 . 8 6 5}$ & 0.706 & $\mathbf{0 . 8 5 8}$ & 0.759 & $\mathbf{0 . 8 7 4}$ & 0.816 \\
\hline
\end{tabular}

Table 9.1c. Heterozygosity was averaged over all five loci, and was then recalculated, leaving out locus A3-5 and leaving out both A3-5 and SH-22. These loci were out of Hardy-Weinberg equilibrium and exhibited a deficit of heterozygotes consistent with the existence of a null allele. Expected heterozygosity exceeded observed heterozygosity in all cases, but differences were rather small (except for $11 \%$ difference at Rainy Lake where gene flow across the highway was low) when only those loci in $\mathrm{H}-\mathrm{W}$ equilibrium were considered. $\mathrm{F}_{\mathrm{ST}}$ has an upper limit equal to the average homozygosity: 0.135 calculated with all loci, 0.142 without locus A3-5, and 0.126 without A3-5 or SH-22. 
In most cases, $\mathrm{H}_{\mathrm{e}}$ still exceeded $\mathrm{H}_{\mathrm{o}}$, even after loci deviating from $\mathrm{H}-\mathrm{W}$ proportions were excluded, probably because we pooled grids together to calculate heterozygosity for sites; if highways reduce small mammal movement, then sites do not represent one panmictic (randomly mating) population. $\mathrm{H}_{\mathrm{e}}$ therefore exceeds $\mathrm{H}_{0}$, because alleles are less often shared among individuals in a subdivided population than in a single panmictic population. This appeared to be especially true for shrews, particularly at Rainy Lake, where gene flow measurements confirm this conclusion. 


\section{$\underline{\text { Red-backed voles }}$}

Lolo red-backed voles

\begin{tabular}{|c|r|r|}
\hline Locus & $\begin{array}{c}\text { Expected } \\
\text { heterozygosity }\end{array}$ & $\begin{array}{c}\text { Observed } \\
\text { heterozygosity }\end{array}$ \\
\hline 4 & 0.890 & $\mathbf{0 . 8 9 3}$ \\
\hline 5 & $\mathbf{0 . 8 7 4}$ & 0.844 \\
\hline 15 & $\mathbf{0 . 9 2 4}$ & 0.906 \\
\hline 19 & $\mathbf{0 . 8 2 9}$ & 0.750 \\
\hline 6 & $\mathbf{0 . 4 8 0}$ & 0.281 \\
\hline 4B & 0.733 & $\mathbf{0 . 7 5 9}$ \\
\hline Average & $\mathbf{0 . 7 8 8}$ & 0.739 \\
\hline $\begin{array}{c}\text { Average } \\
\text { w/out 6 }\end{array}$ & $\mathbf{0 . 8 5 0}$ & 0.830 \\
\hline
\end{tabular}

Lubrecht red-backed voles

\begin{tabular}{|c|r|r|}
\hline Locus & $\begin{array}{c}\text { Expected } \\
\text { heterozygosity }\end{array}$ & $\begin{array}{c}\text { Observed } \\
\text { heterozygosity }\end{array}$ \\
\hline 4 & $\mathbf{0 . 8 4 0}$ & 0.824 \\
\hline 5 & 0.856 & $\mathbf{0 . 8 8 2}$ \\
\hline 15 & 0.839 & $\mathbf{0 . 9 2 2}$ \\
\hline 19 & 0.702 & $\mathbf{0 . 7 1 2}$ \\
\hline 6 & $\mathbf{0 . 6 0 1}$ & 0.385 \\
\hline 4B & 0.660 & $\mathbf{0 . 6 9 2}$ \\
\hline Average & $\mathbf{0 . 7 4 9}$ & 0.736 \\
\hline $\begin{array}{c}\text { Average } \\
\text { w/out 6 }\end{array}$ & 0.779 & $\mathbf{0 . 8 0 6}$ \\
\hline
\end{tabular}

Rainy Lake red-backed voles

\begin{tabular}{|c|r|r|}
\hline Locus & $\begin{array}{c}\text { Expected } \\
\text { heterozygosity }\end{array}$ & $\begin{array}{c}\text { Observed } \\
\text { heterozygosity }\end{array}$ \\
\hline 4 & 0.826 & $\mathbf{0 . 8 9 3}$ \\
\hline 5 & 0.880 & $\mathbf{0 . 9 2 2}$ \\
\hline 15 & $\mathbf{0 . 9 2 0}$ & 0.899 \\
\hline 19 & 0.785 & $\mathbf{0 . 8 1 0}$ \\
\hline 6 & $\mathbf{0 . 5 3 6}$ & 0.481 \\
\hline 4B & $\mathbf{0 . 5 9 0}$ & 0.577 \\
\hline Average & 0.756 & $\mathbf{0 . 7 6 4}$ \\
\hline $\begin{array}{c}\text { Average } \\
\text { w/out 6 }\end{array}$ & 0.800 & $\mathbf{0 . 8 2 0}$ \\
\hline
\end{tabular}


St. Regis red-backed voles

\begin{tabular}{|c|r|r|}
\hline Locus & $\begin{array}{c}\text { Expected } \\
\text { heterozygosity }\end{array}$ & $\begin{array}{c}\text { Observed } \\
\text { heterozygosity }\end{array}$ \\
\hline 4 & $\mathbf{0 . 8 6 6}$ & 0.847 \\
\hline 5 & 0.860 & $\mathbf{0 . 8 6 7}$ \\
\hline 15 & $\mathbf{0 . 9 1 8}$ & 0.881 \\
\hline 19 & $\mathbf{0 . 8 0 3}$ & 0.768 \\
\hline 6 & $\mathbf{0 . 3 4 8}$ & 0.285 \\
\hline 4B & 0.736 & $\mathbf{0 . 7 4 0}$ \\
\hline Average & $\mathbf{0 . 7 5 5}$ & 0.731 \\
\hline $\begin{array}{c}\text { Average } \\
\text { w/out 6 }\end{array}$ & $\mathbf{0 . 8 3 6}$ & 0.821 \\
\hline
\end{tabular}

Table 9.2. Site specific heterozygosity for red-backed voles, averaged over loci with and without locus 6 . Locus 6 showed deviations from Hardy-Weinberg proportions.

Number of alleles per locus for red-backed voles

\begin{tabular}{|l|c|c|c|c|c|c|}
\hline & $\mathbf{4}$ & $\mathbf{5}$ & $\mathbf{1 5}$ & $\mathbf{1 9}$ & $\mathbf{6}$ & 4B \\
\hline Lolo & 14 & 15 & 17 & 14 & 4 & 8 \\
\hline Lubrecht & 12 & 11 & 13 & 8 & 5 & 4 \\
\hline Rainy & 11 & 15 & 21 & 18 & 7 & 10 \\
\hline St. Regis & 13 & 17 & 22 & 16 & 6 & 11 \\
\hline Total & 17 & 20 & 27 & 25 & 9 & 13 \\
\hline
\end{tabular}

Table 9.3. Allelic diversity for red-backed voles, including the total number of alleles recorded in this study. 


\section{$\underline{\text { Deer mice }}$}

Lubrecht deer mice

\begin{tabular}{|c|r|r|}
\hline Locus & $\begin{array}{c}\text { Expected } \\
\text { heterozygosity }\end{array}$ & $\begin{array}{c}\text { Observed } \\
\text { heterozygosity }\end{array}$ \\
\hline 1 & $\mathbf{0 . 8 8 2}$ & 0.565 \\
\hline 6 & 0.930 & $\mathbf{0 . 9 3 3}$ \\
\hline 4 & $\mathbf{0 . 9 0 3}$ & 0.867 \\
\hline 5 & $\mathbf{0 . 9 2 6}$ & 0.889 \\
\hline 10 & $\mathbf{0 . 9 1 2}$ & 0.308 \\
\hline 12 & 0.930 & $\mathbf{0 . 9 5 6}$ \\
\hline Average & $\mathbf{0 . 9 1 4}$ & 0.753 \\
\hline $\begin{array}{c}\text { Average } \\
\text { w/out 10 }\end{array}$ & $\mathbf{0 . 9 1 4}$ & 0.842 \\
\hline $\begin{array}{c}\text { Average } \\
\text { w/out 1 or } 10\end{array}$ & $\mathbf{0 . 9 2 2}$ & 0.911 \\
\hline
\end{tabular}

Rainy Lake deer mice

\begin{tabular}{|c|r|r|}
\hline Locus & $\begin{array}{c}\text { Expected } \\
\text { heterozygosity }\end{array}$ & $\begin{array}{c}\text { Observed } \\
\text { heterozygosity }\end{array}$ \\
\hline 1 & $\mathbf{0 . 8 8 5}$ & 0.828 \\
\hline 6 & 0.894 & $\mathbf{0 . 9 3 1}$ \\
\hline 4 & 0.907 & $\mathbf{0 . 9 6 6}$ \\
\hline 5 & $\mathbf{0 . 9 3 4}$ & 0.931 \\
\hline 10 & $\mathbf{0 . 8 3 8}$ & 0.630 \\
\hline 12 & 0.922 & $\mathbf{0 . 9 6 6}$ \\
\hline Average & $\mathbf{0 . 8 9 7}$ & 0.875 \\
\hline $\begin{array}{c}\text { Average } \\
\text { w/out 10 }\end{array}$ & 0.908 & $\mathbf{0 . 9 2 4}$ \\
\hline $\begin{array}{c}\text { Average } \\
\text { w/out 1 or } 10\end{array}$ & 0.914 & $\mathbf{0 . 9 4 8}$ \\
\hline
\end{tabular}


St. Regis deer mice

\begin{tabular}{|c|r|r|}
\hline Locus & $\begin{array}{c}\text { Expected } \\
\text { heterozygosity }\end{array}$ & $\begin{array}{c}\text { Observed } \\
\text { heterozygosity }\end{array}$ \\
\hline 1 & $\mathbf{0 . 8 7 6}$ & 0.629 \\
\hline 6 & $\mathbf{0 . 9 1 3}$ & 0.837 \\
\hline 4 & 0.891 & $\mathbf{0 . 8 9 3}$ \\
\hline 5 & $\mathbf{0 . 9 0 4}$ & 0.888 \\
\hline 10 & $\mathbf{0 . 8 5 4}$ & 0.419 \\
\hline 12 & 0.819 & $\mathbf{0 . 8 2 6}$ \\
\hline Average & $\mathbf{0 . 8 7 6}$ & 0.749 \\
\hline Average & $\mathbf{0 . 8 8 1}$ & 0.815 \\
w/out 10 & & \\
\hline $\begin{array}{c}\text { Average } \\
\text { w/out 1 or 10 }\end{array}$ & $\mathbf{0 . 8 8 2}$ & 0.861 \\
\hline
\end{tabular}

Tarkio deer mice

\begin{tabular}{|c|r|r|}
\hline Locus & $\begin{array}{c}\text { Expected } \\
\text { heterozygosity }\end{array}$ & $\begin{array}{c}\text { Observed } \\
\text { heterozygosity }\end{array}$ \\
\hline 1 & 0.916 & 0.674 \\
\hline 6 & 0.939 & $\mathbf{0 . 9 4 0}$ \\
\hline 4 & $\mathbf{0 . 8 4 9}$ & 0.824 \\
\hline 5 & 0.913 & $\mathbf{0 . 9 1 6}$ \\
\hline 10 & $\mathbf{0 . 8 6 0}$ & 0.447 \\
\hline 12 & $\mathbf{0 . 9 7 3}$ & 0.941 \\
\hline Average & $\mathbf{0 . 9 0 8}$ & 0.790 \\
\hline Average & $\mathbf{0 . 9 1 8}$ & 0.859 \\
w/out 10 & & \\
\hline Average \\
w/out 1 or 10
\end{tabular}

Table 9.4. Site specific heterozygosity for deer mice, averaged over loci with and without locus 10 and locus 1 .

These loci showed deviations from Hardy-Weinberg proportions.

Number of alleles per locus for deer mice

\begin{tabular}{|l|c|c|c|c|c|c|}
\hline & $\mathbf{1}$ & $\mathbf{6}$ & $\mathbf{4}$ & $\mathbf{5}$ & $\mathbf{1 0}$ & $\mathbf{1 2}$ \\
\hline Lubrecht & 16 & 25 & 14 & 24 & 17 & 24 \\
\hline Rainy & 11 & 18 & 14 & 19 & 14 & 19 \\
\hline St. Regis & 15 & 28 & 15 & 24 & 15 & 22 \\
\hline Tarkio & 21 & 38 & 18 & 24 & 14 & 24 \\
\hline Total & 23 & 54 & 22 & 45 & 25 & 37 \\
\hline
\end{tabular}

Table 9.5. Allelic diversity for deer mice, including the total number of alleles recorded in this study. 


\section{Vagrant shrews}

Lolo vagrant shrews

\begin{tabular}{|c|r|r|}
\hline Locus & $\begin{array}{c}\text { Expected } \\
\text { heterozygosity }\end{array}$ & $\begin{array}{c}\text { Observed } \\
\text { heterozygosity }\end{array}$ \\
\hline A3-5 & $\mathbf{0 . 8 9 3}$ & 0.432 \\
\hline A3-35 & 0.904 & $\mathbf{0 . 9 1 8}$ \\
\hline A4-20 & $\mathbf{0 . 7 7 1}$ & 0.765 \\
\hline A4-5 & $\mathbf{0 . 9 1 9}$ & 0.837 \\
\hline SH-22 & $\mathbf{0 . 7 9 6}$ & 0.510 \\
\hline Average & $\mathbf{0 . 8 5 7}$ & 0.693 \\
\hline $\begin{array}{c}\text { Average w/out } \\
\text { A3-5 }\end{array}$ & $\mathbf{0 . 8 4 8}$ & 0.758 \\
\hline $\begin{array}{c}\text { Average w/out } \\
\text { A3-5 or SH-22 }\end{array}$ & $\mathbf{0 . 8 6 5}$ & 0.840 \\
\hline
\end{tabular}

Rainy Lake vagrant shrews

\begin{tabular}{|c|r|r|}
\hline Locus & $\begin{array}{c}\text { Expected } \\
\text { heterozygosity }\end{array}$ & $\begin{array}{r}\text { Observed } \\
\text { heterozygosity }\end{array}$ \\
\hline A3-5 & $\mathbf{0 . 8 9 1}$ & 0.600 \\
\hline A3-35 & $\mathbf{0 . 8 8 3}$ & 0.808 \\
\hline A4-20 & $\mathbf{0 . 8 8 1}$ & 0.808 \\
\hline A4-5 & $\mathbf{0 . 9 2 5}$ & 0.731 \\
\hline SH-22 & $\mathbf{0 . 8 2 1}$ & 0.654 \\
\hline Average & $\mathbf{0 . 8 8 0}$ & 0.720 \\
\hline $\begin{array}{c}\text { Average w/out } \\
\text { A3-5 }\end{array}$ & $\mathbf{0 . 8 7 7}$ & 0.750 \\
\hline $\begin{array}{c}\text { Average w/out } \\
\text { A3-5 or SH-22 }\end{array}$ & $\mathbf{0 . 8 9 6}$ & 0.782 \\
\hline
\end{tabular}


St. Regis vagrant shrews

\begin{tabular}{|c|r|r|}
\hline Locus & $\begin{array}{c}\text { Expected } \\
\text { heterozygosity }\end{array}$ & $\begin{array}{c}\text { Observed } \\
\text { heterozygosity }\end{array}$ \\
\hline A3-5 & $\mathbf{0 . 8 9 1}$ & 0.451 \\
\hline A3-35 & $\mathbf{0 . 8 6 3}$ & 0.859 \\
\hline A4-20 & $\mathbf{0 . 8 0 5}$ & 0.797 \\
\hline A4-5 & $\mathbf{0 . 9 1 9}$ & 0.819 \\
\hline SH-22 & $\mathbf{0 . 8 0 8}$ & 0.606 \\
\hline Average & $\mathbf{0 . 8 5 7}$ & 0.707 \\
\hline $\begin{array}{c}\text { Average w/out } \\
\text { A3-5 }\end{array}$ & $\mathbf{0 . 8 4 9}$ & 0.771 \\
\hline $\begin{array}{c}\text { Average w/out } \\
\text { A3-5 or SH-22 }\end{array}$ & $\mathbf{0 . 8 6 2}$ & 0.825 \\
\hline
\end{tabular}

Table 9.6. Site specific heterozygosity for vagrant shrews, averaged over loci with and without locus A3-5 and locus SH-

22. These loci showed deviations from Hardy-Weinberg proportions

Number of alleles per locus for vagrant shrews

\begin{tabular}{|l|c|c|c|c|c|}
\hline & $\mathbf{A 3 - 5}$ & $\mathbf{A 3 - 3 5}$ & $\mathbf{A 4 - 2 0}$ & $\mathbf{A 4 - 5}$ & SH-22 \\
\hline Lolo & 16 & 18 & 9 & 20 & 11 \\
\hline Rainy & 14 & 13 & 12 & 19 & 7 \\
\hline St. Regis & 18 & 13 & 9 & 19 & 12 \\
\hline Total & 22 & 22 & 16 & 27 & 15 \\
\hline
\end{tabular}

Table 9.7. Allelic diversity for vagrant shrews, including the total number of alleles recorded in this study. 


\section{APPENDIX 10 - GENETIC DIFFERENCES AMONG SITES}

\section{$\underline{\text { Red-backed voles }}$}

$F_{\mathrm{ST}}$ for red-backed voles among sites: all loci

\begin{tabular}{|l|r|r|r|}
\hline & Lolo & Lubrecht & Rainy \\
\hline Lubrecht & 0.056 & & \\
\hline Rainy & 0.056 & 0.041 & 0.023 \\
\hline St. Regis & 0.029 & 0.051 & 0.040 \\
\hline
\end{tabular}

Table 10.1a. Pairwise $\mathrm{F}_{\mathrm{ST}}$ among sites averaged 0.043 when all loci were included in the calculation.

$F_{\mathrm{ST}}$ for red-backed voles among sites: without locus 6

\begin{tabular}{|l|r|r|r|}
\hline & Lolo & Lubrecht & Rainy \\
\hline Lubrecht & 0.045 & & \\
\hline Rainy & 0.061 & 0.033 & 0.021 \\
\hline St. Regis & 0.028 & 0.025 & 0.025 \\
\hline
\end{tabular}

Table 10.1b. Pairwise $\mathrm{F}_{\mathrm{ST}}$ among sites averaged 0.035 when locus 6 was excluded. Locus 6 showed deviations from Hardy-Weinberg proportions. 
Assignments of red-backed voles among sites: Bayesian likelihood method w/ all loci

\begin{tabular}{|l|r|r|r|r|}
\hline & Lolo & Lubrecht & Rainy & St. Regis \\
\hline Lolo & $\mathbf{0 . 5 9 4}$ & 0.039 & 0.051 & 0.060 \\
\hline Lubrecht & 0.094 & $\mathbf{0 . 7 5 0}$ & 0.101 & 0.086 \\
\hline Rainy & 0.063 & 0.192 & $\mathbf{0 . 7 2 2}$ & 0.073 \\
\hline St. Regis & 0.250 & 0.0192 & 0.127 & $\mathbf{0 . 7 8 1}$ \\
\hline
\end{tabular}

Table 10.2a. Proportion of voles correctly assigned to their population of capture or misassigned to a different site using Bayesian probabilities. Voles were captured in [columns], but assigned in [rows]. Overall $74.2 \%$ classified correctly.

Assignments of red-backed voles among sites: Bayesian method w/out locus 6

\begin{tabular}{|l|r|r|r|r|}
\hline & Lolo & Lubrecht & Rainy & St. Regis \\
\hline Lolo & $\mathbf{0 . 5 3 1}$ & 0.039 & 0.025 & 0.093 \\
\hline Lubrecht & 0.125 & $\mathbf{0 . 7 3 1}$ & 0.101 & 0.132 \\
\hline Rainy & 0.063 & 0.173 & $\mathbf{0 . 7 5 9}$ & 0.099 \\
\hline St. Regis & 0.281 & 0.058 & 0.114 & $\mathbf{0 . 6 7 5}$ \\
\hline
\end{tabular}

Table 10.2b. Proportion of voles correctly assigned to their population of capture or misassigned to a different site using Bayesian probabilities, locus 6 excluded. Locus 6 showed deviations from HardyWeinberg proportions. Voles were captured in [columns], but assigned in [rows]. Overall $69.1 \%$ classified correctly.

Assignments of red-backed voles among sites: distance method (Nei $\left.D_{A}\right)$ w/ all loci

\begin{tabular}{|l|r|r|r|r|}
\hline & Lolo & Lubrecht & Rainy & St. Regis \\
\hline Lolo & $\mathbf{0 . 5 9 4}$ & 0.000 & 0.038 & 0.073 \\
\hline Lubrecht & 0.094 & $\mathbf{0 . 8 0 8}$ & 0.152 & 0.146 \\
\hline Rainy & 0.094 & 0.173 & $\mathbf{0 . 7 0 9}$ & 0.093 \\
\hline St. Regis & 0.219 & 0.0192 & 0.101 & $\mathbf{0 . 6 8 9}$ \\
\hline
\end{tabular}

Table 10.2c. Proportion of voles correctly assigned to their population of capture or misassigned to a different site using Nei's $\mathrm{D}_{\mathrm{A}}$ genetic distance statistic. This test does not require Hardy-Weinberg equilibrium. Voles were captured in [columns], but assigned in [rows]. Overall $70.4 \%$ classified correctly. 


\section{Deer mice}

$\mathrm{F}_{\mathrm{ST}}$ for deer mice among sites: all loci

\begin{tabular}{|l|r|r|r|r|}
\hline & Lolo & Lubrecht & Rainy & St. Regis \\
\hline Lubrecht & 0.054 & & & \\
\hline Rainy & 0.058 & 0.017 & & \\
\hline St. Regis & 0.074 & 0.029 & 0.036 & \\
\hline Tarkio & 0.075 & 0.036 & 0.041 & 0.047 \\
\hline
\end{tabular}

Table 10.3a. Pairwise $\mathrm{F}_{\mathrm{ST}}$ among sites averaged 0.047 when all loci were included in the calculation.

$F_{\mathrm{ST}}$ for deer mice among sites: without locus 10

\begin{tabular}{|l|r|r|r|r|}
\hline & Lolo & Lubrecht & Rainy & St. Regis \\
\hline Lubrecht & 0.049 & & & \\
\hline Rainy & 0.063 & 0.017 & & \\
\hline St. Regis & 0.066 & 0.030 & 0.034 & \\
\hline Tarkio & 0.073 & 0.037 & 0.044 & 0.049 \\
\hline
\end{tabular}

Table 10.3b. Pairwise $\mathrm{F}_{\mathrm{ST}}$ among sites averaged 0.046 when locus 10 was excluded. Locus 10 showed deviations from Hardy-Weinberg proportions.

$F_{\mathrm{ST}}$ for deer mice among sites: without locus 1 or 10

\begin{tabular}{|l|r|r|r|r|}
\hline & Lolo & Lubrecht & Rainy & St. Regis \\
\hline Lubrecht & 0.052 & & & \\
\hline Rainy & 0.067 & 0.017 & & \\
\hline St. Regis & 0.072 & 0.036 & 0.040 & \\
\hline Tarkio & 0.072 & 0.035 & 0.045 & 0.049 \\
\hline
\end{tabular}

Table 10.3c. Pairwise $\mathrm{F}_{\mathrm{ST}}$ among sites averaged 0.048 when locus 1 and locus 10 were excluded due to deviations from Hardy-Weinberg proportions. 
Assignments of deer mice among sites: Bayesian likelihood method w/ all loci

\begin{tabular}{|l|r|r|r|r|r|}
\hline & Lolo & Lubrecht & Rainy & St. Regis & Tarkio \\
\hline Lolo & $\mathbf{0 . 7 6 9}$ & 0.067 & 0.000 & 0.000 & 0.013 \\
\hline Lubrecht & 0.154 & $\mathbf{0 . 7 1 1}$ & 0.103 & 0.011 & 0.000 \\
\hline Rainy & 0.000 & 0.111 & $\mathbf{0 . 7 5 9}$ & 0.034 & 0.013 \\
\hline St. Regis & 0.077 & 0.067 & 0.035 & $\mathbf{0 . 9 5 5}$ & 0.029 \\
\hline Tarkio & 0.000 & 0.044 & 0.103 & 0.056 & $\mathbf{0 . 9 4 5}$ \\
\hline
\end{tabular}

Table 10.4a. Proportion of deer mice correctly assigned to their population of capture or misassigned to a different site using Bayesian probabilities. Mice were captured in [columns], but assigned in [rows].

Overall $89.3 \%$ classified correctly.

Assignments of deer mice among sites: Bayesian likelihood method w/out locus 10

\begin{tabular}{|l|r|r|r|r|r|}
\hline & Lolo & Lubrecht & Rainy & St. Regis & Tarkio \\
\hline Lolo & $\mathbf{0 . 7 6 9}$ & 0.044 & 0.000 & 0.000 & 0.008 \\
\hline Lubrecht & 0.154 & $\mathbf{0 . 7 1 1}$ & 0.103 & 0.023 & 0.004 \\
\hline Rainy & 0.000 & 0.133 & $\mathbf{0 . 6 9 0}$ & 0.028 & 0.017 \\
\hline St. Regis & 0.077 & 0.044 & 0.069 & $\mathbf{0 . 8 9 3}$ & 0.021 \\
\hline Tarkio & 0.000 & 0.067 & 0.138 & 0.056 & $\mathbf{0 . 9 5 0}$ \\
\hline
\end{tabular}

Table 10.4b. Proportion of deer mice correctly assigned to their population of capture or misassigned to a different site using Bayesian probabilities, excluding locus 10. Locus 10 showed deviations from HardyWeinberg proportions. Mice were captured in [columns], but assigned in [rows]. Overall $88.9 \%$ classified correctly.

Assignments of deer mice among sites: Bayesian method w/out locus 1 or 10

\begin{tabular}{|l|r|r|r|r|r|}
\hline & Lolo & Lubrecht & Rainy & St. Regis & Tarkio \\
\hline Lolo & $\mathbf{0 . 8 4 6}$ & 0.044 & 0.000 & 0.000 & 0.017 \\
\hline Lubrecht & 0.077 & $\mathbf{0 . 7 3 3}$ & 0.103 & 0.028 & 0.013 \\
\hline Rainy & 0.000 & 0.089 & $\mathbf{0 . 6 5 5}$ & 0.023 & 0.008 \\
\hline St. Regis & 0.077 & 0.067 & 0.103 & $\mathbf{0 . 8 9 3}$ & 0.025 \\
\hline Tarkio & 0.000 & 0.067 & 0.138 & 0.056 & $\mathbf{0 . 9 3 7}$ \\
\hline
\end{tabular}

Table 10.4c. Proportion of deer mice correctly assigned to their population of capture or misassigned to a different site using Bayesian probabilities, excluding locus 1 and 10. These loci showed deviations from Hardy-Weinberg proportions. Mice were captured in [columns], but assigned in [rows]. Overall $88.5 \%$ classified correctly.

Assignments of deer mice among sites: distance method (Nei $\left.D_{A}\right)$ w/ all loci

\begin{tabular}{|l|r|r|r|r|r|}
\hline & Lolo & Lubrecht & Rainy & St. Regis & Tarkio \\
\hline Lolo & $\mathbf{0 . 8 4 6}$ & 0.133 & 0.069 & 0.000 & 0.025 \\
\hline Lubrecht & 0.077 & $\mathbf{0 . 6 4 4}$ & 0.103 & 0.011 & 0.004 \\
\hline Rainy & 0.000 & 0.111 & $\mathbf{0 . 6 9 0}$ & 0.023 & 0.017 \\
\hline St. Regis & 0.077 & 0.067 & 0.069 & $\mathbf{0 . 9 2 7}$ & 0.067 \\
\hline Tarkio & 0.000 & 0.044 & 0.069 & 0.039 & $\mathbf{0 . 8 8 7}$ \\
\hline
\end{tabular}

Table 10.4d. Proportion of deer mice correctly assigned to their population of capture or misassigned to a different site using Nei's $\mathrm{D}_{\mathrm{A}}$ genetic distance statistic. This test does not require Hardy-Weinberg equilibrium. Mice were captured in [columns], but assigned in [rows]. Overall $86.7 \%$ classified correctly. 


\section{Vagrant shrews}

$F_{\mathrm{ST}}$ for shrews among sites: all loci

\begin{tabular}{|l|r|r|}
\hline & Lolo & Rainy \\
\hline Rainy & 0.034 & \\
\hline St. Regis & 0.012 & 0.036 \\
\hline
\end{tabular}

Table 10.5a. Pairwise $\mathrm{F}_{\mathrm{ST}}$ among sites averaged 0.028 when all loci were included in the calculation.

$F_{\mathrm{ST}}$ for shrews among sites: without locus A3-5

\begin{tabular}{|l|r|r|}
\hline & Lolo & Rainy \\
\hline Rainy & 0.035 & \\
\hline St. Regis & 0.015 & 0.036 \\
\hline
\end{tabular}

Table 10.5b. Pairwise $\mathrm{F}_{\mathrm{ST}}$ among sites averaged 0.029 when A3-5 was excluded. Locus A3-5 showed deviations from Hardy-Weinberg proportions.

$F_{\mathrm{ST}}$ for shrews among sites: without locus A3-5 or SH-22

\begin{tabular}{|l|r|r|}
\hline & Lolo & Rainy \\
\hline Rainy & 0.036 & \\
\hline St. Regis & 0.019 & 0.033 \\
\hline
\end{tabular}

Table 10.5c. Pairwise $\mathrm{F}_{\mathrm{ST}}$ among sites averaged 0.029 when A3-5 and SH-22 were excluded. These loci showed deviations from Hardy-Weinberg proportions. 
Assignments of shrews among sites: Bayesian likelihood method w/ all loci

\begin{tabular}{|l|r|r|r|}
\hline & Lolo & Rainy & St. Regis \\
\hline Lolo & $\mathbf{0 . 6 7 3}$ & 0.154 & 0.181 \\
\hline Rainy & 0.031 & $\mathbf{0 . 8 0 8}$ & 0.009 \\
\hline St. Regis & 0.296 & 0.039 & $\mathbf{0 . 8 1 1}$ \\
\hline
\end{tabular}

Table 10.6a. Proportion of shrews correctly assigned to their population of capture or misassigned to a different site using Bayesian probabilities. Shrews were captured in [columns], but assigned in [rows]. Overall 77.2\% classified correctly.

Assignments of shrews among sites: Bayesian likelihood method w/out A3-5

\begin{tabular}{|l|r|r|r|}
\hline & Lolo & Rainy & St. Regis \\
\hline Lolo & $\mathbf{0 . 6 7 3}$ & 0.192 & 0.198 \\
\hline Rainy & 0.020 & $\mathbf{0 . 7 6 9}$ & 0.004 \\
\hline St. Regis & 0.306 & 0.039 & $\mathbf{0 . 7 9 7}$ \\
\hline
\end{tabular}

Table 10.6b. Proportion of shrews correctly assigned to their population of capture or misassigned to a different site using Bayesian probabilities, excluding locus A3-5. A3-5 showed deviations from Hardy-Weinberg proportions. Shrews were captured in [columns], but assigned in [rows]. Overall $76.1 \%$ classified correctly.

Assignments of shrews among sites: Bayesian method w/out A3-5 or SH-22

\begin{tabular}{|l|r|r|r|}
\hline & Lolo & Rainy & St. Regis \\
\hline Lolo & $\mathbf{0 . 6 6 3}$ & 0.154 & 0.185 \\
\hline Rainy & 0.041 & $\mathbf{0 . 6 9 2}$ & 0.013 \\
\hline St. Regis & 0.296 & 0.154 & $\mathbf{0 . 8 0 2}$ \\
\hline
\end{tabular}

Table 10.6c. Proportion of shrews correctly assigned to their population of capture or misassigned to a different site using Bayesian probabilities, excluding locus A3-5 and SH-22. These loci showed deviations from Hardy-Weinberg proportions. Shrews were captured in [columns], but assigned in [rows]. Overall 75.5\% classified correctly.

Assignments of shrews among sites: distance method (Nei $\left.D_{A}\right)$ w/ all loci

\begin{tabular}{|l|r|r|r|}
\hline & Lolo & Rainy & St. Regis \\
\hline Lolo & $\mathbf{0 . 6 3 3}$ & 0.115 & 0.189 \\
\hline Rainy & 0.041 & $\mathbf{0 . 8 0 8}$ & 0.018 \\
\hline St. Regis & 0.327 & 0.077 & $\mathbf{0 . 7 9 3}$ \\
\hline
\end{tabular}

Table 10.6d. Proportion of shrews correctly assigned to their population of capture or misassigned to a different site using Nei's $\mathrm{D}_{\mathrm{A}}$ genetic distance statistic. This test does not require Hardy-Weinberg equilibrium. Shrews were captured in [columns], but assigned in [rows]. Overall $74.9 \%$ classified correctly. 
Misassignments among sites

\begin{tabular}{|l|l|l|l|l|r|}
\hline & $\begin{array}{l}\text { Misassign } \\
\text { All }\end{array}$ & $\begin{array}{l}\text { Misassign } \\
\text { LR } \mathbf{1 0}\end{array}$ & $\begin{array}{l}\text { Misassign } \\
\text { LR } \mathbf{2 0}\end{array}$ & $\begin{array}{l}\text { Misassign } \\
\text { LR } \mathbf{1 0 0}\end{array}$ & $\begin{array}{r}\text { Total } \\
\text { Analyzed }\end{array}$ \\
\hline red-backed voles & $0.296(93)$ & $0.006(2)$ & $0.003(1)$ & 0.000 & 314 \\
\hline deer mice & $0.133(67)$ & $0.032(16)$ & $0.026(13)$ & $0.018(9)$ & 503 \\
\hline vagrant shrews & $0.251(88)$ & $0.003(1)$ & 0.000 & 0.000 & 351 \\
\hline
\end{tabular}

Table 10.7. The proportion of individuals misassigned among sites was greatly reduced when a likelihood ratio (LR) of at least 10 was used as a cutoff value, below which point individuals were not considered "true" migrants. $\mathrm{LR}=$ [probability of originating in assigned population / probability of originating in capture population]. 


\section{APPENDIX 11 - GENE FLOW WITHIN SITES}

Gene flow across highways for red-backed voles

\begin{tabular}{|l|r|r|r|r|r|}
\hline & \multicolumn{3}{|c|}{$\mathrm{F}_{\mathrm{ST}}$ and Bayesian assignment test } & $\begin{array}{c}\text { Distance } \\
\text { assignmt }\end{array}$ \\
\hline Site & \multicolumn{2}{|c|}{ All loci } & \multicolumn{2}{c|}{ No 6} & All loci \\
\hline & $\mathrm{F}_{\mathrm{ST}}$ & misassign & $\mathrm{F}_{\mathrm{ST}}$ & misassign & misassign \\
\hline Lolo (2-lane) & & & & & \\
\hline same side & $\mathbf{0 . 1 2 0}$ & $\mathbf{0 . 0 8 0}$ & 0.057 & $\mathbf{0 . 0 8 0}$ & $\mathbf{0 . 1 2 0}$ \\
\hline opposite side & 0.089 & 0.154 & $\mathbf{0 . 0 6 9}$ & 0.231 & 0.231 \\
\hline Lubrecht (2-lane) & & & & & \\
\hline same side & $\mathbf{0 . 0 1 9}$ & $\mathbf{0 . 2 6 6}$ & $\mathbf{0 . 0 1 1}$ & 0.302 & $\mathbf{0 . 2 9 2}$ \\
\hline opposite side & 0.014 & 0.274 & 0.008 & $\mathbf{0 . 3 0 0}$ & 0.300 \\
\hline Rainy (2-lane) & & & & & \\
\hline same side & $\mathbf{0 . 0 0 7}$ & 0.423 & $\mathbf{0 . 0 0 7}$ & 0.433 & $\mathbf{0 . 4 2 3}$ \\
\hline opposite side & 0.002 & $\mathbf{0 . 4 0 9}$ & 0.002 & $\mathbf{0 . 3 9 5}$ & 0.500 \\
\hline St. Regis (4-lane) & & & & & \\
\hline same side, hwy & 0.006 & $\mathbf{0 . 3 9 3}$ & 0.006 & $\mathbf{0 . 3 7 0}$ & $\mathbf{0 . 4 0 1}$ \\
\hline opposite side, hwy & $\mathbf{0 . 0 1 1}$ & 0.407 & $\mathbf{0 . 0 1 1}$ & 0.420 & 0.407 \\
\hline same side, far & 0.009 & $\mathbf{0 . 3 9 3}$ & 0.010 & $\mathbf{0 . 3 8 1}$ & $\mathbf{0 . 3 6 9}$ \\
\hline opposite side, far & 0.009 & 0.407 & 0.010 & 0.390 & 0.423 \\
\hline
\end{tabular}

Table 11.1. Gene flow in red-backed voles did not appear to be influenced by highways. We compared genetic differences between animals captured on the same side of the highway, versus those captured on opposite sides of the highway. Comparisons indicating more differentiation and less gene flow are shown in bold: higher $\mathrm{F}_{\mathrm{ST}}$ and lower misassignment rate. At St. Regis in 2001, we made comparisons directly across the highway $(75 \mathrm{~m})$ and across the highway into the forest interior $(240 \mathrm{~m})$. We present values for $\mathrm{F}_{\mathrm{ST}}$ and the Bayesian likelihood-based assignment test with and without locus 6, which showed deviations from Hardy-Weinberg proportions, as well as a genetic distance-based assignment test (Nei's $\mathrm{D}_{\mathrm{A}}$ distance statistic) that does not require $\mathrm{H}-\mathrm{W}$ equilibrium. 
Gene flow across highways for deer mice

\begin{tabular}{|c|c|c|c|c|c|c|c|}
\hline \multirow{3}{*}{ Site } & \multicolumn{6}{|c|}{$\mathrm{F}_{\mathrm{ST}}$ and Bayesian assignmt test } & \multirow{3}{*}{$\begin{array}{c}\begin{array}{c}\text { Distance } \\
\text { assignmt }\end{array} \\
\text { All loci } \\
\text { misassign }\end{array}$} \\
\hline & \multicolumn{2}{|c|}{ All loci } & \multicolumn{2}{|c|}{ No 10} & \multicolumn{2}{|c|}{ No 1 or 10} & \\
\hline & $\mathrm{F}_{\mathrm{ST}}$ & misassign & $\mathrm{F}_{\mathrm{ST}}$ & misassign & $\mathrm{F}_{\mathrm{ST}}$ & misassign & \\
\hline \multicolumn{8}{|l|}{ Lubrecht (2-lane) } \\
\hline same side & 0.021 & 0.409 & 0.030 & 0.254 & 0.024 & 0.437 & $\mathbf{0 . 3 3 7}$ \\
\hline opposite side & 0.022 & 0.423 & 0.023 & 0.385 & 0.029 & 0.385 & 0.404 \\
\hline \multicolumn{8}{|l|}{ St. Regis 2000 (4-lane) } \\
\hline same side & 0.000 & 0.474 & 0.002 & 0.518 & 0.002 & 0.494 & 0.494 \\
\hline opposite side & 0.005 & 0.392 & 0.001 & 0.479 & 0.002 & 0.458 & 0.347 \\
\hline \multicolumn{8}{|l|}{ St. Regis 2001 (4-lane) } \\
\hline same side, hwy & 0.037 & 0.223 & 0.039 & 0.205 & 0.043 & 0.223 & 0.209 \\
\hline opposite side, hwy & $\mathbf{0 . 0 5 7}$ & 0.113 & 0.050 & 0.130 & 0.055 & 0.150 & 0.141 \\
\hline same side, far & $\mathbf{0 . 0 3 7}$ & 0.213 & 0.038 & 0.277 & 0.041 & 0.213 & 0.220 \\
\hline opposite side, far & 0.029 & 0.150 & 0.035 & 0.150 & 0.030 & 0.175 & 0.150 \\
\hline \multicolumn{8}{|l|}{ Tarkio 2000 (4-lane) } \\
\hline same side & 0.025 & 0.235 & 0.028 & 0.235 & 0.029 & 0.222 & 0.259 \\
\hline opposite side & 0.023 & 0.273 & 0.030 & 0.211 & 0.031 & 0.235 & 0.285 \\
\hline \multicolumn{8}{|l|}{ Tarkio 2001 (4-lane) } \\
\hline same side & 0.026 & 0.172 & 0.025 & 0.162 & 0.027 & 0.182 & 0.201 \\
\hline opposite side & 0.022 & 0.155 & 0.019 & 0.186 & 0.017 & 0.224 & 0.220 \\
\hline
\end{tabular}

Table 11.2. Gene flow in deer mice was reduced by 4-lane highways only, and only at St. Regis. We compared genetic differences between animals captured on the same side of the highway, versus those captured on opposite sides of the highway. Comparisons indicating more differentiation and less gene flow are shown in bold: higher $\mathrm{F}_{\mathrm{ST}}$ and lower misassignment rate. At St. Regis in 2001, we made comparisons directly across the highway $(75 \mathrm{~m})$ and across the highway into the forest interior $(240 \mathrm{~m})$. We present values for $\mathrm{F}_{\mathrm{ST}}$ and the Bayesian likelihood-based assignment test with and without locus 1 and locus 10, which showed deviations from Hardy-Weinberg proportions, as well as a genetic distance-based assignment test (Nei's $\mathrm{D}_{\mathrm{A}}$ distance statistic) that does not require H-W equilibrium.

Values shown in Figure 6 are averages across sites for $\mathrm{F}_{\mathrm{ST}}$ computed without 1 or 10 and distance-based misassignment rates. Sample sizes at Lolo and Rainy Lake were too small for analyses to be meaningful. 
Gene flow across highways for vagrant shrews

\begin{tabular}{|c|c|c|c|c|c|c|c|}
\hline \multirow{3}{*}{ Site } & \multicolumn{6}{|c|}{$\mathrm{F}_{\mathrm{ST}}$ and Bayesian assignment test } & \multirow{3}{*}{$\begin{array}{c}\begin{array}{c}\text { Distance } \\
\text { assignmt }\end{array} \\
\text { All loci } \\
\text { misassign }\end{array}$} \\
\hline & \multicolumn{2}{|c|}{ All loci } & \multicolumn{2}{|c|}{ No A3-5 } & \multicolumn{2}{|c|}{ No A3-5 or SH-22 } & \\
\hline & $\overline{\mathrm{F}_{\mathrm{ST}}}$ & misassign & $\mathrm{F}_{\mathrm{ST}}$ & misassign & $\mathrm{F}_{\mathrm{ST}}$ & misassign & \\
\hline \multicolumn{8}{|l|}{ Lolo (2-lane)* } \\
\hline same side & 0.001 & 0.480 & 0.002 & 0.440 & 0.002 & 0.427 & 0.467 \\
\hline opposite side & 0.000 & 0.563 & 0.000 & 0.542 & 0.006 & 0.479 & 0.479 \\
\hline \multicolumn{8}{|l|}{ Rainy (2-lane)* } \\
\hline same side & 0.000 & 0.381 & 0.000 & 0.381 & 0.011 & 0.286 & 0.429 \\
\hline opposite side & 0.061 & 0.063 & 0.056 & 0.063 & 0.081 & 0.063 & 0.063 \\
\hline \multicolumn{8}{|l|}{ St. Regis (4-lane) } \\
\hline same side, hwy & 0.004 & 0.429 & 0.005 & 0.467 & 0.004 & 0.450 & 0.478 \\
\hline opposite side, hwy & 0.014 & 0.342 & 0.013 & 0.317 & 0.008 & 0.360 & 0.325 \\
\hline same side, far & 0.000 & 0.453 & 0.000 & 0.473 & 0.000 & 0.442 & 0.523 \\
\hline opposite side, far & 0.007 & 0.376 & 0.008 & 0.372 & 0.008 & 0.374 & 0.374 \\
\hline
\end{tabular}

Table 11.3. Gene flow in vagrant shrews was reduced by both 2-lane (at Rainy Lake only) and 4-lane highways. We compared genetic differences between animals captured on the same side of the highway, versus those captured on opposite sides of the highway. Comparisons indicating more differentiation and less gene flow are shown in bold: higher $\mathrm{F}_{\mathrm{ST}}$ and lower misassignment rate. At St. Regis in 2001, we made comparisons directly across the highway $(75 \mathrm{~m})$ and across the highway into the forest interior $(240 \mathrm{~m})$. The reduction in gene flow at St. Regis appeared to be unrelated to distance, attributable to the presence of the highway. Highway effects were especially pronounced at Rainy Lake. We present values for $\mathrm{F}_{\mathrm{ST}}$ and the Bayesian likelihoodbased assignment test with and without locus A3-5 and locus SH-22, which showed deviations from Hardy-Weinberg proportions, as well as a genetic distance-based assignment test (Nei's $\mathrm{D}_{\mathrm{A}}$ distance statistic) that does not require $\mathrm{H}-\mathrm{W}$ equilibrium. 